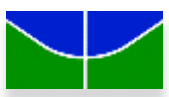

UNIVERSIDADE DE BRASÍLIA

FACULDADE DE ECONOMIA, ADMINISTRAÇÃO, CONTABILIDADE E CIÊNCIA DA INFORMAÇÃO E DOCUMENTAÇÃO
\end{abstract}

CLÁUDIO ARAUJO DE FREITAS GAGO

A MARCAÇÃO A MERCADO COMO METODOLOGIA DE APURAÇÃO DO ESTOQUE DA DÍVIDA PÚBLICA FEDERAL E OS IMPACTOS EM SEUS INDICADORES 


\section{A MARCAÇÃO A MERCADO COMO METODOLOGIA DE APURAÇÃO DO ESTOQUE DA DÍVIDA PÚBLICA FEDERAL E OS IMPACTOS EM SEUS INDICADORES}

Dissertação submetida ao Programa de PósGraduação em Administração da Universidade de Brasília como requisito à obtenção do grau de Mestre em Administração.

Área de concentração: Finanças e Métodos Quantitativos.

Orientador: Prof. Dr. José Carneiro da Cunha Oliveira Neto 


\section{A MARCAÇÃO A MERCADO COMO METODOLOGIA DE APURAÇÃO DO ESTOQUE DA DÍVIDA PÚBLICA FEDERAL E OS IMPACTOS EM SEUS INDICADORES}

Dissertação submetida ao Programa de PósGraduação em Administração da Universidade de Brasília como requisito à obtenção do grau de Mestre em Administração.

Orientador: Prof. Dr. José Carneiro da Cunha Oliveira Neto

Aprovada em: de de 2016.

Banca Examinadora

Prof. Dr. José Carneiro da Cunha Oliveira Neto Instituição:

Julgamento: Assinatura:

Prof. Dr. André Luiz Marques Serrano Instituição:

Julgamento: Assinatura:

Prof. Dr. Marcelo Driemeyer Wilbert Instituição:

Julgamento: Assinatura:

Brasília 


\section{RESUMO}

A gestão da dívida pública pode ser apontada como uma das maiores responsabilidades do governo, tendo como missão a minimização do custo de refinanciamento no longo prazo, mantendo níveis prudentes de risco. O estoque financeiro da dívida pública e os indicadores que compõem o seu perfil representam os principais parâmetros para a implantação e o monitoramento de estratégias de endividamento. Uma importante decisão atribuída ao gestor da dívida pública se refere à definição quanto à metodologia adequada de precificação dos títulos que deve ser adotada na apuração do estoque da dívida pública. Nesse contexto, esta pesquisa tem como objetivo analisar os reflexos de uma possível adoção da marcação a mercado como método de apuração do estoque da dívida pública federal, bem como mensurar os impactos em seus indicadores de custo e risco. Embora os organismos internacionais recomendem a marcação a mercado como metodologia de precificação dos títulos na apuração do estoque da dívida pública, os resultados obtidos por meio da pesquisa survey apontaram que apenas 16\% dos países respondentes informaram apurar e publicar o estoque da dívida pública por esta metodologia. Por outro lado, 50\% dos países participantes declararam utilizar o valor de mercado dos títulos como informação relevante para a gestão da dívida pública. A segunda etapa da pesquisa consistiu na precificação dos títulos da dívida pública federal interna e externa por seus valores de mercado, no período de dezembro de 2010 a dezembro de 2015. Os resultados foram comparados aos valores do estoque e dos demais indicadores da dívida pública publicados pela Secretaria do Tesouro Nacional, calculados pelo preço na curva. As diferenças entre os valores obtidos por meio das duas diferentes metodologias foram mensuradas com a utilização do erro quadrático médio. Verificou-se a existência de diferentes desvios dos preços apurados na curva em relação aos valores de mercado, que são explicados pelas flutuações das taxas de mercado, pelo prazo de maturidade e pelas características de indexação dos títulos públicos. A análise das vantagens e desvantagens de cada metodologia permite concluir que as diferentes mensurações de dívida pública fornecem perspectivas distintas e complementares, proporcionando ao gestor de dívida um conjunto informativo mais completo para a tomada de decisão quanto às estratégias de financiamento da dívida pública.

Palavras-chave: Endividamento Público. Precificação de Títulos Públicos. Marcação a Mercado. Indicadores da Dívida Pública. 


\begin{abstract}
Public debt management can be singled out as one of the greatest responsibilities of the government, with the mission to minimize the refinancing cost in the long run, maintaining prudent risk levels. Public debt stock and the indicators that make up its profile represent the main parameters for debt strategies implementation and monitoring. Public debt managers have the important task to define the appropriate security pricing methodology that they should adopt to determine the stock of public debt. This research aims to analyze the consequences of adopting the mark-to-market method to calculate the federal debt stock, as well as to measure the impacts of its use on cost and risk indicators. Although international organizations recommend mark-to-market as the pricing methodology for securities in the calculation of the public debt stock, the results obtained through a survey showed that only $16 \%$ of the respondent countries reported using this accounting method to determine and publish their public debt stock. On the other hand, $50 \%$ of the participating countries reported using market value as relevant information to the management of public debt. The second stage of the research was to price domestic and external federal public debt securities by their market value in the period from December 2010 to December 2015. The results were compared with stock values and other public debt indicators published by the National Treasury, calculated by the price curve. After that, we measured the differences between the values obtained by the two different methods using the mean squared error criterion. We detected different price deviations on the curve in relation to market values, which are explained by fluctuations in market rates, term to maturity and government bond index characteristics. The analysis of the advantages and disadvantages of each method shows that the different public debt measure strategies offer distinct and complementary perspectives, providing the debt manager with a more complete information set for decision making regarding public debt financing strategies.
\end{abstract}

Keywords: Public Debt. Public Securities Pricing. Mark-to-Market. Public Debt Indicators. 


\section{SUMÁRIO}

1 INTRODUÇÃ

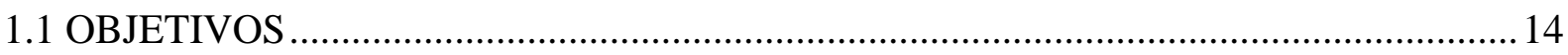

1.1.1 Objetivo Geral ......................................................................................................................14

1.1.2 Objetivos Específicos...........................................................................................14

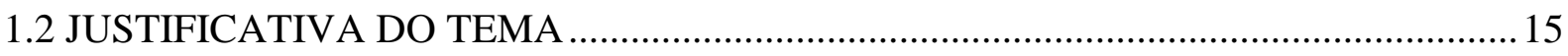

2 REFERENCIAL TEÓRICO .............................................................................................16

2.1 ORIGEM, CONCEITOS E CLASSIFICAÇÕES DA DÍVIDA PÚBLICA .......................16

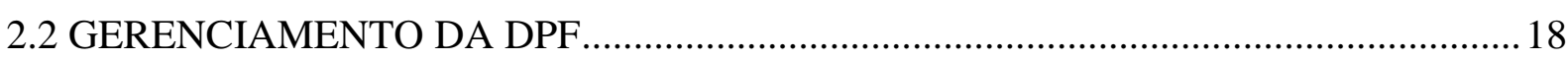

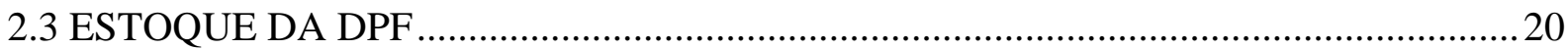

2.3.1 Valor Nominal Atualizado (VNA)...................................................................................21

2.3.2 Precificação pela curva ou pela taxa interna de retorno (TIR)...................................23

2.3.3 Precificação pelo valor de mercado (Marcação a Mercado - MaM) ...........................25

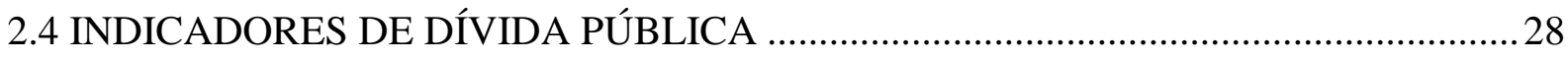

2.4.1 Composição, por indexador .....................................................................................29

2.4.2 Prazo médio....................................................................................................................29

2.4.3 Custo médio.....................................................................................................................................32

3 PROCEDIMENTOS METODOLÓGICOS ...................................................................34

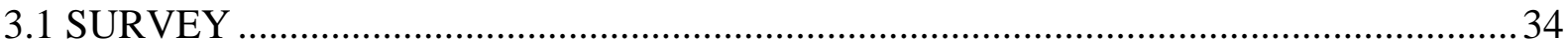

3.1.1 Amostragem ........................................................................................................................34

3.1.2 Coleta de dados ...........................................................................................................34

3.1.3 Análise dos dados..............................................................................................................35

3.2 ANÁLISE COMPARATIVA ENTRE AS DIFERENTES METODOLOGIAS DE PRECIFICAÇÃO DOS TÍTULOS NA APURAÇÃO DO ESTOQUE DA DPF........................35

3.2.1 Amostragem ...........................................................................................................................................35

3.2.2 Coleta de dados .......................................................................................................39

3.2.3 Análise dos dados.......................................................................................................40

3.2.3.1 Mensuração das diferenças apuradas entre as séries de preços de mercado e preços

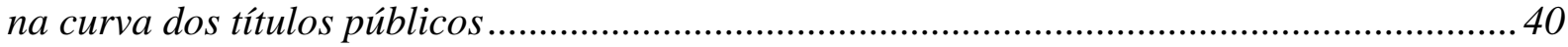

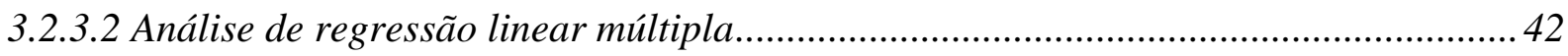

3.2.3.3 Mensuração do impacto das diferentes metodologias de precificação nos indicadores

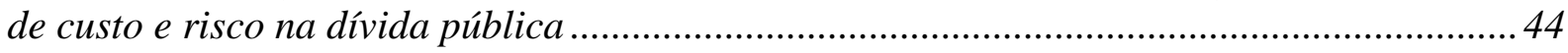

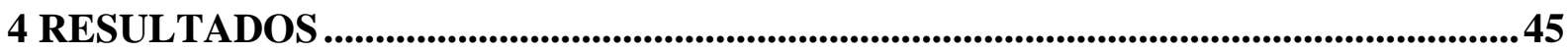

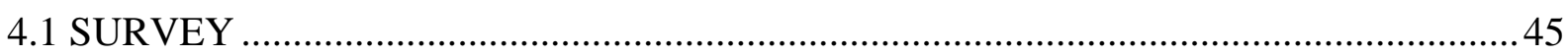

4.2 ANÁLISE COMPARATIVA ENTRE AS DIFERENTES METODOLOGIAS DE PRECIFICAÇÃO DOS TÍTULOS NA APURAÇÃO DO ESTOQUE DA DPF.......................50

4.2.1 Dívida Pública Mobiliária Federal interna - DPMFi .......................................................50 
4.2.2 Dívida Pública Mobiliária Federal externa - DPMFe 67

4.2.3 Estoque agrupado da DPF . . .78

4.2.4 Análise das variáveis que explicam o RMSE do preço na curva em relação ao preço de mercado 83

4.2.5 Indicadores da DPF 86

4.2.5.1 Composição 86

4.2.5.2 Prazo médio, Duration e ATM 87

4.2.5.3 Custo médio mensal. 93

5 DISCUSSÃO 103

6 CONCLUSÕES E CONSIDERAÇÕES FINAIS 112

6.1 LIMITAÇÕES DA PESQUISA 115

6.2 SUGESTÕES DE PESQUISAS FUTURAS. 116

REFERÊNCIAS 118

APÊNDICE A - QUESTIONÁRIO. 123

APÊNDICE B - RESPOSTAS À PESQUISA SURVEY. 124

APÊNDICE C - DADOS DA REGRESSÃO MÚLTIPLA 130 


\section{LISTA DE FIGURAS}

Figura 1 - Representação gráfica dos fluxos da NTN-B 150806 na precificação para o dia

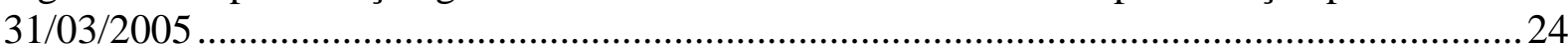

Figura 2 - Exemplo de cálculo do preço na curva da NTN-B 150806 ...................................24

Figura 3 - Exemplo de cálculo do preço de mercado da NTN-B 150806.............................27 


\section{LISTA DE QUADROS}

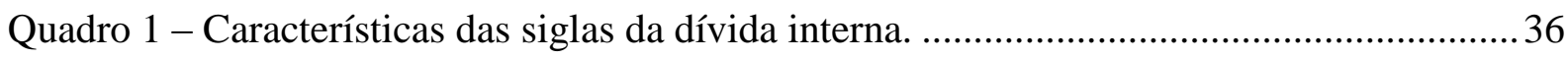

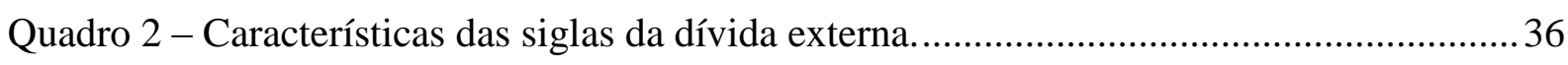

Quadro 3 - Títulos da DPMFi incluídos na pesquisa.......................................................... 37

Quadro 4 - Títulos da DPMFe incluídos na pesquisa .............................................................. 39

Quadro 5 - Países que responderam ao questionário, por nível de desenvolvimento econômico 45

Quadro 6 - Objetivos específicos e conclusões da pesquisa ............................................ 115 


\section{LISTA DE GRÁFICOS}

Gráfico 1 - Metodologia de precificação dos títulos na apuração e divulgação do estoque da dívida pública adotada pelos países

Gráfico 2 - Metodologia de precificação dos títulos na apuração e divulgação do estoque da dívida pública adotada pelos países de economia avançada.

Gráfico 3 - Metodologia de precificação dos títulos na apuração e divulgação do estoque da dívida pública adotada pelos mercados emergentes e economias de média renda.

Gráfico 4 - Metodologia de precificação dos títulos na apuração e divulgação do estoque da dívida pública adotada pelos países de baixa renda

Gráfico 5 - Participação de países que pretendem adotar a marcação a mercado como metodologia oficial de apuração do estoque da dívida pública

Gráfico 6 - Participação de países que utiliza o valor de mercado da dívida pública no gerenciamento da dívida pública.

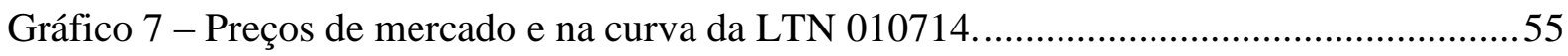

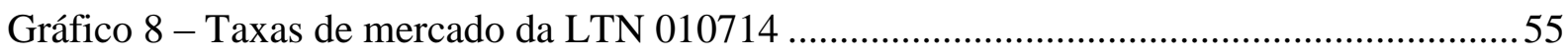

Gráfico 9 - Preços de mercado e na curva da LTN 010116 ...................................................56

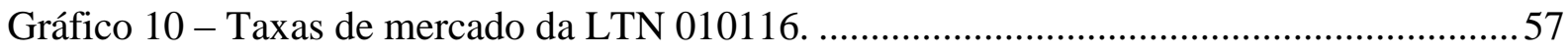

Gráfico 11 - Preços de mercado e na curva da NTN-F 010115 .............................................58

Gráfico 12 - Taxas de mercado da NTN-F 010115 ...........................................................59

Gráfico 13 - Preços de mercado e na curva da NTN-F 010118 .............................................60

Gráfico 14 - Preços de mercado e na curva da NTN-F 010119 ..............................................60

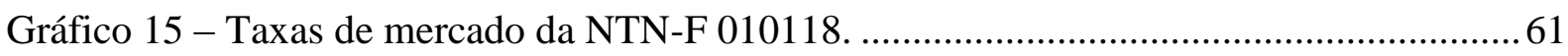

Gráfico 16 - Preços de mercado e na curva da NTN-B 150840. ............................................63

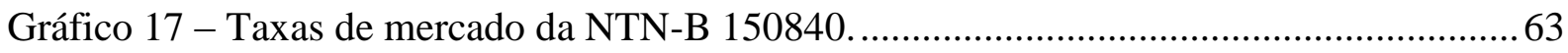

Gráfico 18 - Preços de mercado e na curva da NTN-B 150545 ............................................64

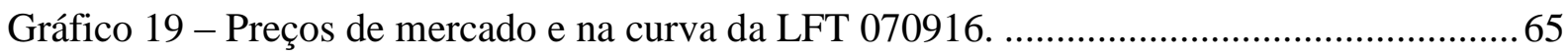

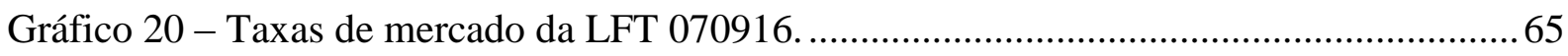

Gráfico 21 - Preços de mercado e na curva da LFT 010318. .................................................66

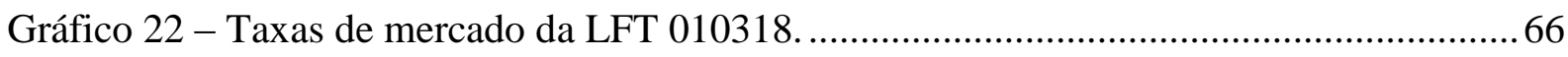

Gráfico 23 - Preços de mercado e na curva do Euro 2021 ....................................................69

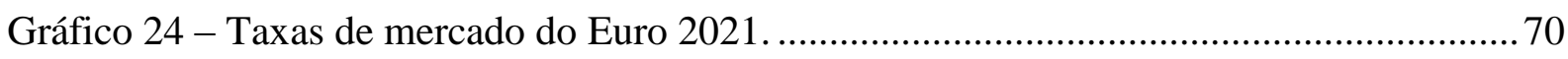

Gráfico 25 - Taxas de mercado dos bônus Global ................................................................ 71

Gráfico 26 - Preços de mercado e na curva da Global 2019................................................. 72

Gráfico 27 - Preços de mercado e na curva da Global 2019 N.............................................. 73

Gráfico 28 - Preços de mercado e na curva da Global 2021.................................................. 74

Gráfico 29 - Preços de mercado e na curva da Global 2030................................................ 75 
Gráfico 30 - Preços de mercado e na curva da Global 2041 ................................................ 76

Gráfico 31 - Preços de mercado e na curva da Global BRL 2028.......................................... 77

Gráfico 32 - Taxas de mercado do Global BRL 2028 .......................................................... 78

Gráfico 33 - Estoque da LTN, em valores de mercado e na curva........................................78

Gráfico 34 - Estoque da NTN-F, em valores de mercado e na curva.....................................79

Gráfico 35 - Estoque da NTN-B, em valores de mercado e na curva..................................... 80

Gráfico 36 - Estoque da LFT, em valores de mercado e na curva........................................... 80

Gráfico 37 - Estoque dos bônus Euro, em valores de mercado e na curva............................. 81

Gráfico 38 - Estoque dos bônus Global, em valores de mercado e na curva........................... 82

Gráfico 39 - Estoque dos bônus Global BRL, em valores de mercado e na curva.................. 82

Gráfico 40 - Estoque agregado da DPF, em valores de mercado e na curva......................... 83

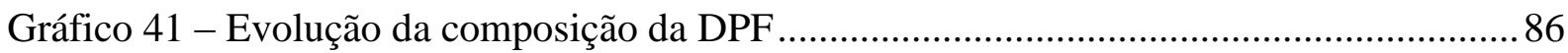

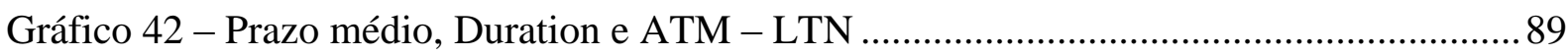

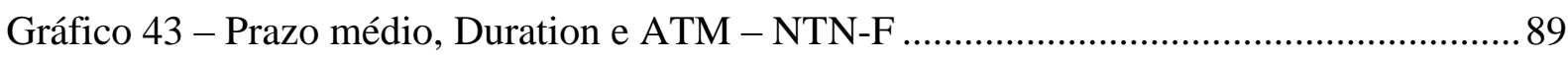

Gráfico 44 - Prazo médio, Duration e ATM - NTN-B ........................................................... 90

Gráfico 45 - Prazo médio, Duration e ATM - LFT ............................................................. 91

Gráfico 46 - Prazo médio, Duration e ATM - Euro ............................................................. 91

Gráfico 47 - Prazo médio, Duration e ATM - Global ............................................................92

Gráfico 48 - Prazo médio, Duration e ATM - Global BRL ................................................... 93

Gráfico 49 - Custo médio mensal (\% a.m.) - LTN 010116 ...................................................96

Gráfico 50 - Custo médio mensal (\% a.m.) - NTN-F 010118 ............................................. 97

Gráfico 51 - Custo médio mensal (\% a.m.) - NTN-B 150840 .............................................. 98

Gráfico 52 - Custo médio mensal (\% a.m.) - LFT 010318 .................................................... 99

Gráfico 53 - Custo médio mensal (\% a.m.) - Euro 2021 ........................................................ 101

Gráfico 54 - Custo médio mensal (\% a.m.) - Global 2021 .................................................... 101

Gráfico 55 - Custo médio mensal (\% a.m.) - Global BRL 2028 .......................................... 102 


\section{LISTA DE TABELAS}

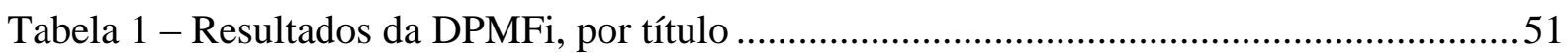

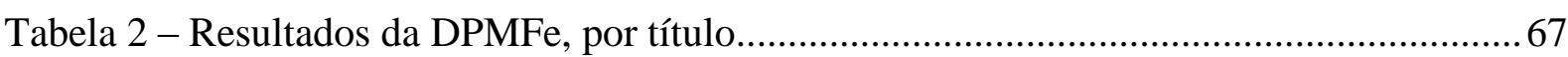

Tabela 3 - Resultados da análise de regressão múltipla $-1^{\circ}$ modelo ...................................... 84

Tabela 4 - Resultados da análise de regressão múltipla $-2^{\circ}$ modelo ...................................... 84

Tabela 5 - Resultados de RMSE da participação de cada categoria, em pontos percentuais .. 87

Tabela 6 - Resultados de prazo médio, duration e ATM ...................................................... 88

Tabela 7 - Resultados do custo médio mensal dos títulos da DPMFi.....................................94

Tabela 8 - Resultados do custo médio mensal dos títulos da DPMFe .................................. 100 


\section{INTRODUÇÃO}

A dívida pública representa um dos mais relevantes indicadores para as finanças públicas de um país (MEDEIROS, 2003). A gestão do endividamento pode ser considerada uma das maiores responsabilidades do governo, tendo impacto significativo não só nas contas públicas como também no nível de bem-estar da sociedade (CABRAL, 2015; COLBANO; LEISTER, 2015).

A preocupação com o aumento do nível de endividamento público e suas consequências negativas para as contas públicas vem despertando crescente interesse pelo tema, tanto no meio acadêmico quanto por parte de governos e organismos internacionais (BAGHDASSARIAN, 2003; CABRAL; LOPES, 2004; DEMBIERMONT et al., 2015).

Embora a evolução do estoque financeiro da dívida pública e sua relação com o produto interno bruto do país possam ser consideradas as variáveis de maior relevância para a sustentabilidade da dívida pública, esta análise não se limita ao tamanho do endividamento (MEDEIROS, 2003). O gerenciamento da dívida pública tem como missão a minimização do custo de refinanciamento no longo prazo, respeitando-se a manutenção de níveis prudentes de risco. Neste sentido, a qualidade do endividamento público é expressa por seus indicadores de custo e risco, os quais representam importantes parâmetros para a implantação e o monitoramento de estratégias da dívida pública (COLBANO, LEISTER, 2015; GIAMBIAGI, ALÉM, 2011; MEDEIROS, 2003; PEDRAS, 2003).

Deve-se ressaltar, nesse contexto, a importância da definição da metodologia de precificação dos títulos adotada na apuração do estoque da dívida pública, não apenas pela determinação do nível de endividamento do país, como também pelo impacto provocado no cálculo dos demais indicadores da dívida pública.

Em vista da recomendação do Fundo Monetário Internacional pela marcação a mercado como metodologia de precificação dos títulos da dívida pública, este trabalho tem como objetivo analisar os reflexos de uma possível adoção deste método precificação dos títulos na apuração do estoque da dívida pública federal brasileira, bem como os impactos nos seus indicadores tradicionais de custo e risco.

O primeiro capítulo do trabalho traz, além desta contextualização introdutória, os objetivos e a justificativa da pesquisa. O capítulo dois apresenta uma revisão da literatura acerca do tema estudado, onde são explorados aspectos referentes aos conceitos e classificações da 
dívida pública, às diferentes metodologias de apuração de estoque da Dívida Pública Federal DPF e aos indicadores tradicionais de custo e risco que compõem o seu perfil.

No capítulo três estão detalhados os procedimentos metodológicos adotados na pesquisa, assim como os parâmetros assumidos no estudo empírico, que foi realizado por dois métodos distintos: num primeiro momento, uma pesquisa survey, buscando identificar os métodos de apuração de estoque mais adotado internacionalmente; a segunda etapa, de abordagem quantitativa, consistiu na comparação da série histórica de preços de mercado e preços na curva dos títulos públicos e os reflexos nos indicadores da DPF; na sequência, foram analisadas as variáveis que explicam as diferenças nos preços apurados pelas diferentes metodologias.

Os resultados obtidos no survey e nos cálculos do estoque da dívida pública federal pelas diferentes metodologias, assim como seus principais indicadores, são apresentados e analisados no capítulo quatro, enquanto o capítulo cinco é dedicado à discussão sobre os resultados e suas implicações para a gestão da dívida pública federal brasileira.

Por fim, no capítulo seis são feitas as considerações finais da pesquisa, incluindo-se as conclusões e limitações deste estudo, além de sugestões para futuras pesquisas.

\subsection{OBJETIVOS}

\subsubsection{Objetivo Geral}

Analisar o impacto de uma possível adoção da marcação a mercado como metodologia de precificação dos títulos na apuração do estoque da dívida pública federal - DPF, bem como avaliar os reflexos nos seus indicadores de custo e risco.

\subsubsection{Objetivos Específicos}

a) Identificar as diferentes metodologias de cálculo do estoque da dívida mobiliária adotadas e/ou recomendadas por organismos internacionais, como o Banco Mundial e o Fundo Monetário Internacional, e pelos órgãos responsáveis pela administração da dívida pública nos diversos países;

b) Calcular, por meio da precificação dos títulos públicos, o estoque da dívida pública federal brasileira utilizando a marcação a mercado como método de apuração e comparar os resultados obtidos aos valores divulgados pelo método de precificação pela curva adotado atualmente pelo Brasil; 
c) Identificar as variáveis que explicam as diferenças apuradas entre os preços na curva e os preços de mercado dos títulos públicos;

d) Mensurar o impacto das diferentes metodologias de apuração do estoque nos indicadores de custo e risco que compõem o perfil da dívida pública;

e) Apontar vantagens e desvantagens de uma possível adoção da marcação a mercado como método de precificação dos títulos na apuração do estoque da DPF.

\subsection{JUSTIFICATIVA DO TEMA}

Em face da recomendação do Fundo Monetário Internacional pela adoção da marcação a mercado como método de precificação dos títulos da dívida pública no cálculo de seu estoque, justifica-se uma investigação aprofundada acerca das diferentes metodologias de apuração do estoque da dívida pública e suas implicações. Neste contexto, esta pesquisa representa um importante avanço para os órgãos responsáveis pela administração da dívida pública federal brasileira - Banco Central do Brasil e Secretaria do Tesouro Nacional - no sentido de contribuir para a melhoria na qualidade das informações produzidas e para o aperfeiçoamento das práticas adotadas na gestão da DPF.

Do ponto de vista acadêmico, a pesquisa busca preencher uma lacuna na produção científica a respeito da metodologia de precificação de títulos no cálculo do estoque e dos indicadores da DPF.

A administração da dívida pública pode ser apontada como uma das maiores responsabilidades do governo. As decisões de hoje sobre estratégias de financiamento têm implicações não só para o momento atual, mas também para as futuras gerações. A gestão eficiente da dívida pública, que tem como missão a redução do custo de refinanciamento da DPF no longo prazo mantendo níveis prudentes de risco, abre espaço para a ampliação de despesas em outras áreas relevantes para a sociedade, o que aponta no sentido da melhoria da qualidade do gasto público (CABRAL, 2015; COLBANO, LEISTER, 2015). Neste sentido, o aprimoramento das práticas na administração da dívida pública representa uma contribuição social significativa na medida em que impacta substancialmente não só as finanças governamentais, mas também, em última análise, o nível de bem-estar social. 


\section{REFERENCIAL TEÓRICO}

Os fundamentos teóricos que dão sustentação à pesquisa estão apresentados nesse capítulo, que está estruturado em quatro tópicos: as origens, conceitos básicos e classificações da dívida pública; o gerenciamento da DPF; as diferentes metodologias de precificação dos títulos na apuração do estoque da DPF; e os indicadores de custo e risco que compõem o seu perfil.

\subsection{ORIGEM, CONCEITOS E CLASSIFICAÇÕES DA DÍVIDA PÚBLICA}

O setor público precisa atender a uma série de demandas da sociedade, prestando serviços e fazendo investimentos nas áreas de infraestrutura, segurança pública, saúde, educação, dentre outras. O surgimento do estado de bem-estar social, que atribuiu ao Estado o papel de promover o crescimento econômico e garantir os direitos sociais, se refletiu em expressiva expansão nas despesas públicas ao longo dos anos (BRESSER-PEREIRA, 1996). Para obter os recursos necessários, o governo tem a arrecadação tributária como sua principal fonte de receitas.

Esta forma de financiamento, porém, tem limitações impostas por princípios do Direito Tributário, como o princípio da capacidade contributiva e o princípio da vedação ao confisco. O primeiro estabelece que sempre que possível, os impostos terão caráter pessoal e serão graduados de acordo com a capacidade econômica do contribuinte. Já o princípio da vedação ao confisco impõe ao Estado uma limitação ao poder de tributar, proibindo-o de utilizar tributo com efeito de confisco (BRASIL, 1988).

Dadas estas limitações tributárias, o Estado brasileiro fez uso recorrente da emissão de moeda para o financiamento do déficit público. Entretanto, a partir da criação do Plano Real, em 1994, iniciou-se uma nova etapa em relação ao regime fiscal no Brasil, que passou a recorrer de forma mais frequente à emissão de dívida como fonte de financiamento do Estado (GIAMBIAGI; ALÉM, 2011; LIMA; SAMPAIO; GAGLIANONE, 2005).

Cabe destacar que a contração de dívida não deve ser vista como algo necessariamente perverso, sobretudo quando estes recursos são destinados a investimentos que vão servir à sociedade por um longo período. Nessas condições, a emissão de dívida, que será paga pelas gerações futuras, promove uma forma mais equitativa de distribuir o custo do investimento entre seus beneficiários (ALESINA; PERROTI, 1995; NOSBUSCH, 2008; PEDRAS, 2003; PEREIRA, 2009). 
Todavia, nos últimos anos, o tema "dívida pública" vem ganhando crescente importância, tanto por parte dos governos e organismos internacionais, como no meio acadêmico, em virtude dos efeitos negativos para as contas públicas provocados pela elevação do nível de endividamento público (BAGHDASSARIAN, 2003; CABRAL; LOPES, 2004; DEMBIERMONT et al., 2015).

A análise histórica da evolução do endividamento público no Brasil realizada por Pedras (2003) mostra que, a partir de 1995, a dívida pública brasileira passou a apresentar uma trajetória de elevação acentuada, que pode ser explicada por uma conjugação de fatores, dentre os quais se destacam: o reconhecimento de passivos contingentes e a manutenção de taxas de juros elevadas em virtude da política monetária restritiva.

A preocupação com o crescimento da dívida pública brasileira tem despertado o interesse por estudos com foco na análise da sustentabilidade da dívida pública brasileira no longo prazo, tais como os trabalhos de Baghdassarian (2006), Borges (2006), Correia e Meurer (2008), Medeiros (2003) e Pedras (2003).

A condição fundamental de sustentabilidade de longo prazo da dívida pública requer que a expectativa do valor presente dos superávits primários futuros seja igual ou superior ao estoque atual da dívida pública (BAGHDASSARIAN, 2006; CORREIA; MEURER, 2008; PEDRAS, 2003). Caso o mercado perceba a incapacidade do governo em honrar os pagamentos da dívida pública, não estará mais disposto a financiá-lo, comprometendo a rolagem da dívida. Essa análise leva em conta as expectativas de taxa de juros, de superávits primários e de taxa de crescimento da economia, variáveis que determinam a dinâmica da relação dívida/PIB (PEDRAS, 2003).

Neste sentido, o nível de endividamento, expressado pelo indicador dívida/PIB, pode ser considerado o parâmetro mais adequado para se avaliar a sustentabilidade da dívida pública no longo prazo, uma vez que este indicador mostra a dívida pública em termos relativos à produção econômica do país (GIAMBIAGI; ALÉM, 2011). No entanto, tendo em conta o objetivo deste estudo - analisar o impacto de uma possível adoção da marcação a mercado como método de apuração do estoque da dívida pública federal, bem como os reflexos nos seus indicadores de custo e risco - o estoque da dívida pública apurado pelas diferentes metodologias será expresso em seus valores absolutos ao longo desta pesquisa.

Deve-se ressaltar ainda que o monitoramento de outros aspectos do endividamento, como os indicadores tradicionais de custo e risco da dívida, permite uma análise mais completa sobre a sustentabilidade da dívida pública de um país, além de compor um conjunto relevante de informações para a tomada de decisão sobre estratégias de financiamento (GIAMBIAGI; 
ALÉM, 2011; MEDEIROS, 2003; PEDRAS, 2003). Isso aponta para a importância da mensuração acurada não só do tamanho do endividamento e da relação dívida/PIB, mas também dos demais indicadores da dívida pública, como a composição, o prazo médio e o custo médio, os quais serão detalhados nas seções seguintes.

A dívida pública pode ser definida como a captação de recursos junto à coletividade, que, em contrapartida, celebra contratos com o governo (dívida contratual) ou recebe títulos públicos em que o governo se compromete a pagar uma remuneração àqueles que lhe emprestaram valores financeiros (dívida mobiliária) (PEREIRA, 2009).

Uma importante conceituação a respeito da dívida pública se refere à diferenciação entre a dívida bruta, que considera apenas os passivos do governo em poder do mercado, e a dívida líquida, que leva em consideração também seus ativos (MEDEIROS, 2003; SILVA; MEDEIROS, 2009).

Outra classificação que merece destaque é quanto à sua origem. Segundo o critério brasileiro, a dívida pública pode ser classificada em interna ou doméstica (títulos ou contratos denominados na moeda local) e externa (títulos ou contratos denominados em outras moedas) (MEDEIROS, 2003; SILVA; MEDEIROS, 2009).

A análise realizada nesse trabalho limita-se à dívida pública federal mobiliária bruta, nela incluídas as dívidas mobiliária interna e externa de responsabilidade do Tesouro Nacional em mercado. Não estão incluídas neste conceito, portanto, a carteira de títulos em poder do Banco Central, a base monetária ${ }^{1}$, as dívidas das empresas estatais e dos governos estaduais e municipais. Esse é o indicador regularmente divulgado por meio do Relatório Mensal da Dívida Pública Federal - RMD e da Nota para a Imprensa - Mercado Aberto, pela Secretaria do Tesouro Nacional e pelo Banco Central do Brasil, respectivamente, além de ser usado como referência na elaboração do Plano Anual de Financiamento - PAF.

\subsection{GERENCIAMENTO DA DPF}

O conceito de Equivalência Ricardiana, definido por Robert Barro (1974), pode ser considerado a principal referência teórica para o estudo do gerenciamento da dívida. Segundo esta abordagem, a substituição do financiamento via tributação pela emissão de dívida não afetaria o nível de atividade econômica do país.

\footnotetext{
${ }^{1}$ Passivo monetário do Banco Central, também conhecido como emissão primária de moeda. Inclui o total de cédulas e moedas em circulação e os recursos da conta Reservas Bancárias (BANCO CENTRAL DO BRASIL, 2016).
} 
No caso de um aumento do gasto público via elevação da tributação, a renda disponível do setor privado se reduziria. Desta forma, a diminuição dos gastos privados compensaria o aumento dos gastos públicos. De maneira similar, caso o aumento dos gastos do governo seja financiado por uma elevação do endividamento público, os agentes aumentariam suas poupanças em função da expectativa de aumento da carga tributária futura como consequência da elevação do endividamento. Nesse sentido, o aumento da poupança privada reduziria o consumo privado, anulando o efeito do acréscimo dos gastos do governo sobre o crescimento econômico. Isto tornaria a decisão entre elevar a carga tributária ou o nível de endividamento público indiferente, o que apontaria para a conclusão de que o gerenciamento ativo da dívida pública seria irrelevante (COLBANO; LEISTER, 2015).

O modelo é proposto sob as seguintes premissas: i) agentes possuem horizonte de planejamento infinito; ii) os mercados são completos; iii) os impostos são não-distorcivos; e iv) a função utilidade das famílias leva em consideração a preocupação com as gerações futuras (BARRO, 1974).

Entretanto, há evidências de que tais pressupostos não se confirmam de forma tão restritiva como o modelo propõe. Um dos pontos que enfraquecem a validade da Equivalência Ricardiana é a presença de impostos distorcivos, ou seja, impostos que promovem alterações na alocação de recursos da economia. Uma estrutura tributária distorcida gera impactos diretos sobre o nível de crescimento econômico e de bem-estar social. Neste cenário, o governo deve buscar a suavização da tributação ao longo do tempo, minimizando as distorções decorrentes da arrecadação de receitas, estratégia conhecida como Tax Smoothing (ALVES, 2009; BOHN, 1990; COLBANO; LEISTER, 2015).

Neste sentido, o relaxamento dessas premissas implicaria na importância da gestão ativa da dívida pública no sentido de buscar uma composição entre os diferentes instrumentos de endividamento de forma a criar uma imunização contra flutuações nas variáveis macroeconômicas que afetam o orçamento do governo (ALVES, 2009; BAGHDASSARIAN, 2003; BOHN, 1990; BONOMO et al, 2003; SILVA; CABRAL; BAGHDASSARIAN, 2009).

Dentre os principais objetivos da administração da dívida pública, deve-se destacar a obtenção de uma composição de vencimentos que proporcione ao Tesouro Nacional a minimização dos custos no longo prazo (TOBIN, 1963).

O Plano Anual de Financiamento, instrumento por meio do qual o Tesouro Nacional divulga aos agentes de mercado e à sociedade em geral os objetivos, diretrizes e metas que serão observados na gestão da Dívida Pública Federal em um determinado ano, expõe que a missão da gestão da Dívida Pública Federal "é suprir de forma eficiente as necessidades de 
financiamento do governo federal, ao menor custo no longo prazo, respeitando-se a manutenção de níveis prudentes de risco" (SECRETARIA DO TESOURO NACIONAL, 2015b, p. 9).

De maneira análoga, o Revised Guidelines for Public Debt Management apresenta como principal objetivo da gestão da dívida pública garantir que os governos tenham suas necessidades de financiamento atendidas ao menor custo possível no médio e longo prazos, consistente com um grau prudente de risco (BANCO MUNDIAL; FUNDO MONETÁRIO INTERNACIONAL, 2014). Nota-se que esses dois documentos recentes fornecem uma definição mais rica da missão da gestão da DPF ao considerar a relação de trade-off existente entre risco e custo da dívida pública.

Tendo em vista as definições apresentadas, pode-se determinar como atribuição central do gestor de dívida o cálculo e o monitoramento de um conjunto abrangente de indicadores, tais como composição, prazo médio e percentual vincendo em 12 meses, que formam o perfil da dívida pública e provêm informações relevantes quanto aos seus riscos ${ }^{2}$ de mercado e de refinanciamento (SILVA; CABRAL; BAGHDASSARIAN, 2009).

Neste contexto, o gerenciamento da dívida pública precisa contar com parametrizações que possibilitem a apuração de indicadores consolidados de dívida pública. Isto permite o planejamento das ações futuras e o monitoramento dos resultados alcançados (FARAGLIA; MARCET; SCOTT, 2008), além de representar uma importante referência para o comparativo entre o perfil do endividamento dos diversos países (DEMBIERMONT et al., 2015). Na seção seguinte, apresentam-se os conceitos relativos ao estoque e aos indicadores tradicionais de custo e risco da DPF.

\subsection{ESTOQUE DA DPF}

Esta seção tem como objetivo apresentar os conceitos referentes ao estoque da dívida pública, bem como demonstrar matematicamente os métodos de precificação dos títulos públicos.

O estoque da Dívida Pública Federal (DPF) pode ser considerado um dos mais importantes indicadores das finanças públicas de um país (MEDEIROS, 2003). Trata-se do montante financeiro do endividamento apurado em uma determinada data, somando-se a Dívida

\footnotetext{
2 O risco de mercado está relacionado às variações no preço dos títulos em função da flutuação das variáveis de mercado que o afetam, como taxas de juros, de câmbio e de inflação, enquanto o risco de refinanciamento representa o risco de o Tesouro Nacional ter de se submeter a elevados custos para se financiar no curto prazo ou, em último caso, não conseguir captar os recursos necessários para tal (ALVES; SILVA, 2009).
} 
Pública Mobiliária Federal interna (DPMFi) e a Dívida Pública Federal Mobiliária externa (DPFMe) (SECRETARIA DO TESOURO NACIONAL, 2015e).

O primeiro conceito que deve ser mencionado é o de estoque físico, o qual representa a quantidade de cada um dos títulos na carteira ao final do mercado do último dia útil de cada mês. Entretanto, para se calcular o estoque financeiro da dívida pública, deve-se determinar o preço unitário (PU) de cada um dos títulos na data de apuração do estoque. Esta etapa, chamada de precificação, pode ser realizada por diferentes métodos, conforme veremos a seguir. Desta forma, o estoque financeiro de cada título da dívida pública é apurado pela multiplicação de sua quantidade física pelo seu preço unitário (SECRETARIA DO TESOURO NACIONAL, 2015c).

\subsubsection{Valor Nominal Atualizado (VNA)}

O VNA representa o valor nominal atribuído ao título na sua data-base, atualizado periodicamente pela variação do indexador desse papel, como mostra a fórmula abaixo (SECRETARIA DO TESOURO NACIONAL, 2015c).

$V N A=$ Valor Nominal na data - base $x(1+$ variação do indexador $)$

Usando como exemplo um tipo de título tradicional da Dívida Pública Federal brasileira, a Nota do Tesouro Nacional - série B (NTN-B), indexado ao IPCA ${ }^{3}$, pode-se entender melhor o funcionamento deste cálculo (SECRETARIA DO TESOURO NACIONAL, 2015c).

Valor nominal da NTN-B na data-base (15/07/2000): R \$ 1.000,000000

Variação acumulada do IPCA entre 15/07/2000 e 31/03/2005: 50,7907417\%

VNA da NTN-B em 31/03/2005: R \$ 1.000,00 x 1,507907417= R\$ 1.507,907417

Dois conceitos usualmente utilizados na apuração da dívida pública são os de valor de face e valor nominal. Apesar da proximidade entre os dois termos, convêm diferenciá-los. Enquanto o valor de face se refere apenas ao valor do principal a ser pago no vencimento do título, o valor nominal consiste deste valor, acrescido da parcela dos juros acumulados no

\footnotetext{
${ }^{3}$ Índice Nacional de Preços ao Consumidor Amplo: índice oficial usado como referência para o regime de metas de inflação, calculado e divulgado mensalmente pelo Instituto Brasileiro de Geografia e Estatística - IBGE (SECRETARIA DO TESOURO NACIONAL, 2015a).
} 
período e ainda não pagos (DEMBIERMONT et al., 2015). Considerando essa terminologia, o conceito de VNA equivale ao de valor de face.

Apesar de representar uma variável fundamental para a precificação, o valor de face não pode ser considerado uma boa aproximação do valor real de um título, sobretudo em mercados em que haja flutuação intensa das taxas de juros. A simples apuração do valor de face, que não é afetado pelas taxas de juros, é insuficiente para a determinação do preço dos títulos, podendo apresentar valores significativamente diferentes daqueles calculados por metodologias mais acuradas, que serão vistas nas próximas seções (BUTKIEWICZ, 1983; COX; HIRSCHHORN, 1983; DEMBIERMONT et al., 2015; SEATER, 1981; TANNER, 1979).

Cox e Hirschhorn (1983) calcularam a série histórica do valor de mercado da dívida pública norte-americana e compararam à série de valores de face no período de 1942 a 1980, demonstrando a limitação do valor de face como representação do valor de mercado da dívida no período investigado.

O alicerce fundamental da matemática financeira é que valores em datas diferentes são grandezas que só podem ser comparadas e somadas algebricamente após serem movimentadas para uma mesma data, através da aplicação da(s) taxa(s) de desconto adequada(s) (PUCCINI, 2002).

Neste sentido, precificar um título público significa descontar o seu fluxo pela(s) adequada(s) taxa(s) de desconto para uma determinada data (TAVARES; TAVARES, 2009). Em outras palavras, trata-se de calcular o somatório do valor presente de cada um dos fluxos de principal e de juros do título (cotação) e multiplicá-lo por seu valor nominal atualizado (VNA), como mostram as fórmulas abaixo (BONOMO et al., 2003; SECRETARIA DO TESOURO NACIONAL, 2015c).

$$
\operatorname{Cotação}=\sum_{t=0}^{n} \frac{F t}{(1+i)^{t}}
$$

Onde:

$F t$ : fluxo de principal e juros do título no tempo t, em termos percentuais do valor de face;

$t$ : fração ano entre a data de apuração da cotação e a data de vencimento do fluxo;

$i$ : taxa de desconto. Na precificação pela curva, trata-se da taxa interna de retorno média das emissões; na precificação pelo preço de mercado, trata-se da taxa de mercado do título (yield) praticada na data de referência do cálculo. 


\subsubsection{Precificação pela curva ou pela taxa interna de retorno (TIR)}

Por essa metodologia, o estoque é apurado com base na posição de carteira avaliada pelo preço da curva de rentabilidade intrínseca dos títulos (SECRETARIA DO TESOURO NACIONAL, 2015d). Isso significa que cada emissão de um título é precificada até o seu vencimento usando como taxa de desconto para determinação da sua cotação a própria taxa interna de retorno - TIR da sua emissão original, sem considerar as flutuações das taxas de mercado.

Essa é a metodologia oficial atualmente utilizada na apuração e divulgação do estoque da dívida pública mobiliária federal, tanto pelo Banco Central do Brasil, controlado por meio do Selic ${ }^{4}$, como pela Secretaria do Tesouro Nacional.

Podemos chegar ao preço na curva da NTN-B com vencimento em 15/08/2006 utilizando exemplo publicado no documento "Precificação de títulos públicos" (SECRETARIA DO TESOURO NACIONAL, 2015c). É importante notarmos que, por esta metodologia, um mesmo título pode assumir diferentes preços em uma mesma data, uma vez que cada emissão é precificada utilizando como taxa de desconto a sua própria TIR de emissão.

O preço das NTN-B é calculado pela fórmula abaixo.

$$
P U=\operatorname{cotação~} x V N A=\left[\left[\frac{(1+\text { cupom })^{0,5}-1}{(1+i)^{\frac{d u 1}{252}}}\right]+\left[\frac{(1+\text { cupom })^{0,5}-1}{(1+i)^{\frac{d u 2}{252}}}\right]+\ldots+\left[\frac{(1+\text { cupom })^{0,5}}{(1+i)^{\frac{d u n}{252}}}\right]\right] \times V N A
$$

Onde:

$d u$ : representa o número de dias úteis entre a data de apuração do preço (inclusive) e a data de vencimento do fluxo do título (exclusive).

$i$ : na precificação pela curva, trata-se da taxa interna de retorno média das emissões, o que é matematicamente equivalente a precificar cada emissão pela sua própria TIR até o vencimento do título.

\footnotetext{
${ }^{4}$ Sistema Especial de Liquidação e Custódia - Selic: Sistema informatizado que se destina à custódia de títulos escriturais de emissão do Tesouro Nacional, bem como ao registro e à liquidação de operações com os referidos títulos. A taxa Selic, por sua vez, é a taxa de juros básica da economia, definida pelo Banco Central, que serve como referência para outras taxas de juros da economia brasileira (BANCO CENTRAL DO BRASIL, 2016; SECRETARIA DO TESOURO NACIONAL, 2015a).
} 
cupom: taxa que determina os fluxos periódicos de pagamento de juros (\% a.a.). Nas NTN-B, essa taxa é de $6 \%$ a.a. (equivalente a $2,9563 \%$ a.s.).

VNA: R\$ 1.000 na data-base (15/07/2000), atualizado pela taxa Selic até a data da precificação.

A Figura abaixo mostra a representação gráfica da precificação da NTN-B 150806 para o dia 31/03/2005.

Figura 1 - Representação gráfica dos fluxos da NTN-B 150806 na precificação para o dia 31/03/2005

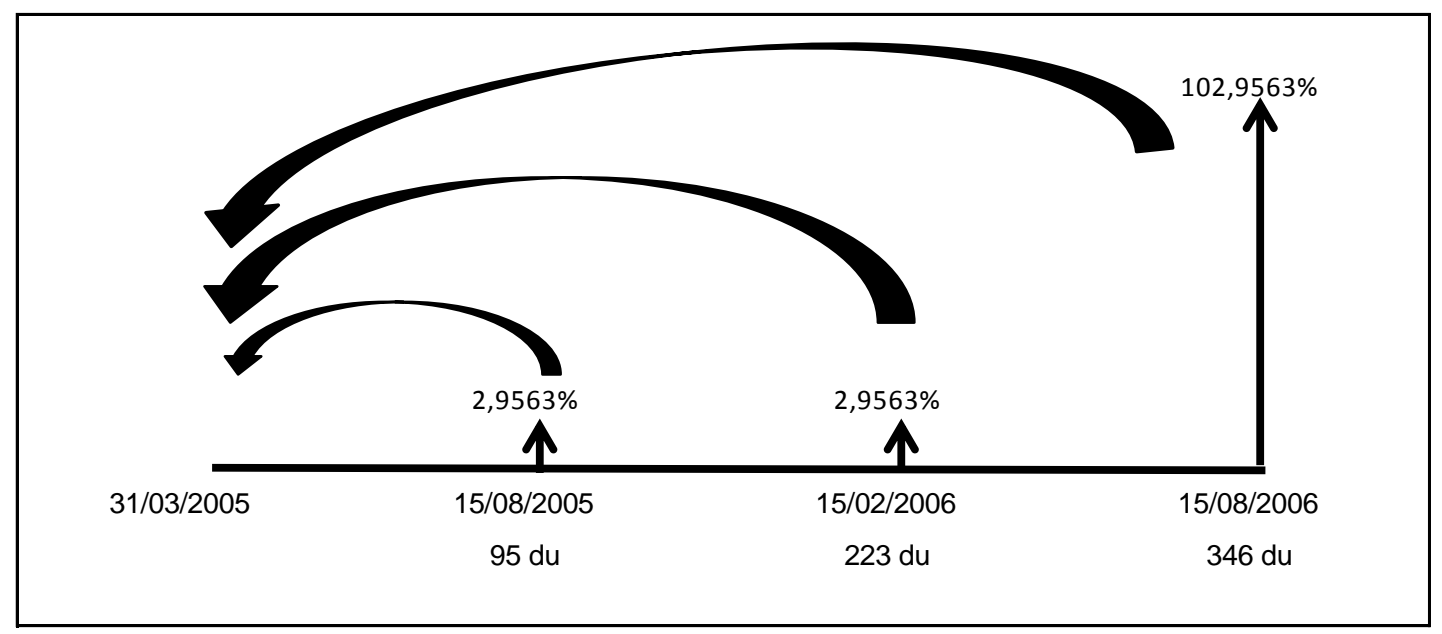

Fonte: Secretaria do Tesouro Nacional, 2015c.

Logo, temos:

Figura 2 - Exemplo de cálculo do preço na curva da NTN-B 150806

Taxa de emissão da NTN-B 150806 no leilão do dia 16/02/2004: 8,35\% a.a.

Data da apuração: 31/03/2005

Cupom: $6 \%$ a.a. (taxa efetiva equivalente a 2,9563\% ao semestre)

Cotação em 31/03/2005: $\left[\left(1,06^{0,5}-1\right) /\left(1,0835^{(95 / 252)}\right)\right]+\left[\left(1,06^{0,5}-1\right) /\left(1,0835^{(223 / 252)}\right)\right]+$ $\left[\left(1,06^{0,5}\right) /\left(1,0835^{(346 / 252)}\right)\right]=97,8435 \%$

Preço da NTN-B 150806 em 31/03/2005: cotação (\%) x VNA = $97,8435 \%$ x R\$1.507,907417 = R\$ 1.475,389394

Fonte: Secretaria do Tesouro Nacional, 2015c. 


\subsubsection{Precificação pelo valor de mercado (Marcação a Mercado - MaM)}

O Government Finance Statistics Manual 2014 - GFSM 2014, documento publicado pelo Fundo Monetário Internacional - FMI contendo diretrizes a serem seguidas na produção de estatísticas governamentais, enuncia que os títulos da dívida pública devem ser avaliados por seus valores de mercado, isto é, como se eles fossem negociados em operações de mercado na data de referência da apuração do estoque (FUNDO MONETÁRIO INTERNACIONAL, 2014).

Outro manual de responsabilidade do FMI, External Debt Statistics: Guide for Compilers and Users, que serve como referência para os países na produção de estatísticas da dívida externa, é mais específico ao apresentar, no seu capítulo dois (The Measurement of External Debt: Definition and Core Accounting Principles), o conceito de valor de mercado para títulos da dívida pública. Segundo o documento, o valor de um título de dívida deve ser determinado pelo seu preço de mercado em vigor na data de referência de sua apuração. O preço de mercado é definido como o valor monetário que compradores estão dispostos a pagar para adquirir um título de vendedores dispostos a negociá-lo. A fonte ideal do preço de mercado de um determinado título de dívida é um mercado financeiro organizado ou outro em que é negociado em considerável volume e seu preço de mercado é listado em intervalos regulares. $\mathrm{Na}$ ausência de tal fonte, o valor de mercado pode ser estimado mediante o desconto dos pagamentos futuros a uma taxa de mercado adequada (FUNDO MONETÁRIO INTERNACIONAL, 2013).

Tais publicações estão em consonância com o System of National Accounts 2008 - 2008 SNA, o qual pode ser definido como um conjunto de conceitos, definições, classificações e regras contábeis que orientam a compilação das Contas Nacionais. Este manual, produzido em parceria pela Organização das Nações Unidas - ONU, a Comissão Europeia, a Organização para a Cooperação e Desenvolvimento Econômico - OCDE, o Fundo Monetário Internacional - FMI e o Banco Mundial, também recomenda a precificação dos passivos, com exceção da dívida contratual, por seus preços de mercado por parte dos escritórios de administração de dívida pública na avaliação da sua posição de estoque. O documento afirma ainda que esta metodologia de precificação se mostra apropriada quaisquer que sejam as características dos títulos, como tipo de indexação, prazo de vencimento ou pagamento de cupom de juros.

A regulamentação da marcação a mercado para os fundos de investimento no Brasil se deu em 15 de fevereiro de 2002, com a publicação da Circular $n^{\circ} 3.086$ pelo Banco Central do Brasil, tendo como objetivo proteger os investidores e reduzir o risco sistêmico potencial. Por 
meio deste documento, o Bacen instruiu mais enfaticamente que os títulos de renda fixa nas carteiras dos fundos de investimento passassem a ser atualizados pelo seu valor de mercado. Foram especificados os critérios e a metodologia a serem utilizados para que os procedimentos praticados pelos fundos de investimento brasileiros entrassem em conformidade com os padrões contábeis internacionais (MORI; TAVARES; BUENO, 2006).

De acordo com o documento, os títulos e valores mobiliários devem ser ajustados diariamente por seus valores de mercado, computando-se a valorização ou a desvalorização em contrapartida à adequada conta de receita ou despesa, no resultado do período (BANCO CENTRAL DO BRASIL, 2002).

Seguindo esta orientação, a Associação Brasileira das Entidades dos Mercados Financeiro e de Capitais - Anbima, órgão que representa as instituições que atuam no mercado de capitais brasileiro com o objetivo de apoiar a evolução deste mercado, publicou seu código de regulação e melhores práticas contendo instrução para que as instituições participantes adotem a Marcação a Mercado (MaM) no registro dos ativos financeiros e valores mobiliários componentes das carteiras dos Fundos de Investimento que administrem (ANBIMA, 2011).

Segundo esta publicação, a MaM consiste em registrar os títulos, para efeito de valorização e cálculo de cotas dos Fundos de Investimento, pelos respectivos preços negociados no mercado, em casos de ativos líquidos ou, quando este preço não é observável, por uma estimativa adequada de preço que o ativo teria em uma eventual negociação feita no mercado (ANBIMA, 2011).

O Manual de Marcação a Mercado da BM\&F Bovespa (2015) define este procedimento como essencial para a identificação dos verdadeiros valores dos ativos, possibilitando a obtenção do preço pelo qual cada um dos ativos que compõem uma determinada carteira pode ser negociado no mercado.

Do ponto de vista matemático, a marcação a mercado é orientada pelo mesmo conceito apresentado em relação à precificação pela curva: um título vale o somatório do valor presente de seus fluxos futuros. A diferença em relação a este modelo de precificação fica exclusivamente por conta da taxa de desconto utilizada. Enquanto, na primeira, cada emissão do título é precificada até o seu vencimento usando como taxa de desconto a própria taxa interna de retorno da sua emissão, como mostrado na seção anterior, na marcação a mercado todas as emissões de um determinado título, independentemente do preço e da data da emissão, são precificados usando como taxa de desconto a taxa de mercado na data de apuração. Neste sentido, os preços dos títulos públicos avaliados por este método refletem as oscilações das suas 
taxas de mercado e, por conseguinte, representam o valor mais próximo daquele que seria praticado numa eventual transação na data de apuração.

Destarte, pode-se demonstrar a precificação da NTN-B 150806 pela marcação a mercado utilizando-se o exemplo supracitado, porém, neste caso, usando a taxa de mercado do título na data da precificação como taxa de desconto (SECRETARIA DO TESOURO NACIONAL, 2015c).

\section{Figura 3 - Exemplo de cálculo do preço de mercado da NTN-B 150806}

Taxa de mercado da NTN-B 150806 em 31/03/2005: 10,88\% a.a. Cotação em 31/03/2005: $\left[\left(1,06^{0,5}-1\right) /\left(1,1088^{(95 / 252)}\right)\right]+\left[\left(1,06^{0,5}-1\right) /\left(1,1088^{(223 / 252)}\right)\right]+$ $\left[\left(1,06^{0,5}\right) /\left(1,1088^{(346 / 252)}\right)\right]=94,8861 \%$

Logo, temos:

Preço da NTN-B 150806 em 31/03/2005= cotação $(\%) \times$ VNA = $94,8861 \%$ x R\$ $1.507,907417=\mathbf{R} \$ \mathbf{1 . 4 3 0 , 7 9 4 5 4 0}$

Fonte: Secretaria do Tesouro Nacional, 2015c.

Neste contexto, uma das mais importantes tarefas atribuídas ao gestor da dívida se refere à definição quanto ao método de precificação dos títulos na apuração do estoque. Apesar de se tratar de um conceito aparentemente simples, há uma discussão relativamente ampla que envolve a metodologia mais adequada para se calcular o risco de mercado devido a divergências acerca do método de apuração do estoque, que é o elemento básico para uma medida de risco de mercado. O valor da dívida deveria ser marcado a mercado, como são tratados os ativos financeiros pelos bancos, por exemplo, ou marcado pela curva, isto é, usando a taxa interna de retorno pela qual cada título foi originalmente vendido? (BONOMO et al., 2003; SILVA; CABRAL; BAGHDASSARIAN, 2009).

Apesar de não haver consenso sobre esta questão, a apuração da dívida pública pelo valor de mercado parece ser a mais apropriada, já que a precificação pela taxa de mercado geraria o valor pelo qual um determinado título seria negociado numa eventual operação (BAGHDASSARIAN, 2003; COX, HIRSCHHORN, 1983).

O princípio fundamental para a avaliação de passivos do governo deveria tomar por base o valor que seria exigido pelo mercado, caso o governo decidisse antecipar o pagamento daquela dívida (MEDEIROS, 2003). 
Neste mesmo sentido, Mori, Tavares e Bueno (2006) concluem que os agentes devem realizar a precificação dos títulos a valor de mercado, independentemente da natureza da sua rentabilidade e do seu risco, de forma a refletirem de forma integral a realidade dos preços praticados no mercado.

Entretanto, no que se refere aos órgãos responsáveis pela administração da DPF, não se deve considerar um procedimento metodológico certo ou errado sem a adequada avaliação dos impactos gerados a partir da adoção de uma determinada metodologia. Mais do que isso, essa decisão deve levar em consideração a compatibilidade das estatísticas produzidas com o que se pretende medir (BONOMO et al., 2003).

Embora a evolução do estoque da dívida seja considerada a variável de análise mais relevante, não se pode restringir a análise da dívida pública ao seu tamanho. É fundamental que o gestor possa dispor de um conjunto abrangente de indicadores que retratem de forma mais detalhada a qualidade do endividamento e o auxiliem na formulação e no monitoramento das estratégias de financiamento da dívida pública (MEDEIROS, 2003).

Neste ponto, cabe destacar que a definição da metodologia de apuração do estoque terá impacto direto nos demais indicadores da dívida pública, uma vez que a fórmula de cálculo e as variáveis utilizadas devem respeitar o padrão metodológico adotado na apuração do estoque. Desta forma, a mensuração do indicador deve ser conceitualmente coerente com o método de apuração do estoque da dívida. Esta uniformidade metodológica é fundamental para que se possa fazer a adequada interpretação de seus resultados.

\subsection{INDICADORES DE DÍVIDA PÚBLICA}

Uma questão central para o gestor da dívida pública se refere à determinação da composição e do perfil de vencimentos da dívida pública que esteja em consonância com o objetivo de reduzir o custo de refinanciamento no longo prazo mantendo os riscos em níveis prudentes. Neste sentido, é fundamental que haja parametrizações que permitam o cálculo e o monitoramento de um conjunto de indicadores, formando um retrato da dívida pública. A correta interpretação e análise de seus resultados possibilitam uma melhor avaliação da qualidade do endividamento público (SILVA; CABRAL; BAGHDASSARIAN, 2009; SILVA; MEDEIROS, 2009).

Nesta seção são apresentados os principais indicadores que compõem o perfil da Dívida Pública Federal administrada pelo Tesouro Nacional. 


\subsubsection{Composição, por indexador}

A composição da dívida mostra a participação de cada indexador em relação ao estoque total. A partir do cálculo do estoque da dívida, é possível decompô-lo em categorias de acordo com os diferentes fatores de remuneração da dívida, os quais representam classes distintas de risco. Assim, a composição da DPF indica a participação relativa no estoque de cada uma dessas categorias, sendo elas: prefixados (taxas de juros fixas), índices de preços (títulos indexados à inflação), taxa flutuante (instrumentos com taxas de juros variáveis) e câmbio (dívida denominada ou referenciada em moeda estrangeira) (SECRETARIA DO TESOURO NACIONAL, 2015b).

A formulação de estratégias para a dívida pública envolve escolhas com o objetivo de se alcançar um adequado balanceamento entre custos e riscos. Um elemento-chave nesse processo é a definição do perfil desejado para a composição da dívida no longo prazo, isto é, um benchmark (ALVES, 2009).

O benchmark constitui uma referência de longo prazo para o perfil do portfólio de dívida usada para nortear as estratégias de financiamento de curto e médio prazos, podendo ser expresso por um conjunto de indicadores relevantes para a dívida, tais como a composição do estoque por tipo de remuneração, o prazo médio e o percentual vincendo em 12 meses (ALVES, 2009; CABRAL; LOPES, 2004).

O artigo clássico de Markowitz (1952) representa um dos principais fundamentos teóricos para a formação de uma carteira ótima de endividamento para a administração pública, reconhecendo a relação de trade-off entre custo e risco da dívida pública. De maneira análoga à Teoria Moderna do Portfólio, que se baseia na média, variância e covariância dos retornos de ativos na formação de portfólio diversificado ótimo, pode-se derivar uma fronteira eficiente no plano de custos e riscos, com base nas diversas composições de dívida. Neste sentido, a composição ótima da dívida pública é expressa pela combinação dos diferentes instrumentos de financiamento que ofereça o menor risco para um determinado nível de custo ou o menor custo para um nível de risco assumido.

\subsubsection{Prazo médio}

É o indicador que mensura o prazo médio ponderado dos vencimentos da DPF, levandose em consideração os fluxos futuros de principal e de juros, em valores presentes (SECRETARIA DO TESOURO NACIONAL, 2015e). Apresenta-se a seguir a fórmula de cálculo do prazo médio dos títulos da DPF. 
Prazo Médio $=\frac{\sum_{t=0}^{n} t \times F t \times(1+i)^{-t}}{\sum_{t=0}^{n} F t \times(1+i)^{-t}}$

Onde,

Ft: fluxo de principal e juros do título no tempo t;

$t$ : fração ano entre a data de e vencimento do fluxo;

$i$ : taxa média das emissões do título na data de referência do cálculo.

Trata-se de um importante indicador de risco de refinanciamento da DPF. Dentre os modelos teóricos que abordam a relação de trade-off entre risco e custo da dívida, destaca-se o modelo de Giavazzi e Pagano (1990), segundo o qual um encurtamento dos prazos de vencimento da dívida representa um risco de refinanciamento elevado. Sob tais circunstâncias, um momento de crise de confiança geraria uma situação em que o governo seria forçado a se financiar sob condições desfavoráveis, o que poderia se refletir em aumento do prêmio pelo risco oferecido pelo Tesouro para se refinanciar e, em última instância, geraria um aumento do custo de refinanciamento da dívida ${ }^{5}$.

Desta forma, um alongamento do prazo médio da DPF representa uma boa estratégia de gerenciamento da dívida no sentido de reduzir a necessidade de captação de recursos pelo governo em momentos adversos (GIAVAZZI; PAGANO, 1990; LLUSSÁ, 1998; MENDONÇA, 2004).

Apesar de alguns países utilizarem uma mesma nomenclatura para determinado indicador, a experiência internacional mostra que as estatísticas que mensuram a dívida pública obedecem, muitas vezes, a metodologias distintas, podendo variar significativamente. Uma vez que esses indicadores representam uma importante ferramenta para se estabelecer comparativos entre o perfil da dívida de diversos países, é fundamental que se conheça a metodologia de cálculo utilizada para que se possa fazer essa análise de forma justa (DEMBIERMONT et al., 2015; DIPPELSMAN et al., 2012; LEISTER, 2012; MEDEIROS, 2003; SILVA; CABRAL; BAGHDASSARIAN, 2009).

Os indicadores de maturidade da dívida pública podem ser apontados como um bom exemplo desta falta de consenso metodológico internacional.

\footnotetext{
${ }^{5}$ Ver item 2.4.3.
} 
A Macaulay's Duration é um indicador que mensura a variação aproximada do preço de um título para pequenas oscilações ${ }^{6}$ na taxa de retorno. Matematicamente, representa a derivada primeira da função preço do título em relação à sua taxa de retorno. Um título com duration de 3 anos, por exemplo, aumentará aproximadamente 0,03 ponto percentual no seu preço no caso de uma redução de 0,01 ponto percentual da taxa de retorno. Trata-se de uma medida bastante usada pelo setor privado para avaliar a sensibilidade do valor dos títulos à variação da taxa de juros, e, em diversos países, é utilizada como indicador de prazo da dívida pública, uma vez que representa a maturidade média dos fluxos de pagamento de principal e de juros de um título ou carteira de títulos (BONOMO et al., 2003; MACAULAY, 1938; SECRETARIA DO TESOURO NACIONAL, 2003b).

Macaulay (1938) expressou a duration de um título pela seguinte fórmula:

$$
\text { Duration }=\frac{\sum_{t=0}^{n} t \times F t \times(1+i)^{-t}}{\sum_{t=0}^{n} F t \times(1+i)^{-t}}
$$

Onde,

$F t$ : fluxo de principal e juros do título no tempo t;

$t$ : fração ano entre a data de apuração da duration e a data de vencimento do fluxo;

$i$ : taxa de mercado do título (yield) praticada na data de referência do cálculo.

O prazo médio é o indicador de maturidade atualmente utilizado pelo Tesouro Nacional como meta no gerenciamento da dívida pública. Diferentemente do cálculo da duration, que utiliza a taxa de mercado (yield) na data de referência do cálculo como taxa de desconto dos fluxos, no cálculo do prazo médio os fluxos futuros de cada emissão são descontados por sua própria TIR da emissão original, alinhado, portanto, ao padrão metodológico adotado na apuração do estoque pela curva. Desta forma, o prazo médio dos títulos não captura integralmente as flutuações da taxa de juros.

O ATM (Average Term to Maturity), por sua vez, pode ser considerado o mais simples dos indicadores de maturidade, já que os títulos são computados por seus valores de face e não são considerados os pagamentos de cupons de juros, o que torna o cálculo compatível com a apuração do estoque pelo valor de face dos títulos. Apesar de apresentar tais inconsistências, o

\footnotetext{
${ }^{6}$ Uma vez que a variação do preço de um título não é uma função linear das oscilações da sua taxa de retorno, essa interpretação da duration é adequada apenas para pequenas variações da taxa, tornando-se menos precisa a medida que se aumentam essas variações.
} 
ATM é um indicador de maturidade bastante disseminado entre os departamentos de gestão da dívida pública (Debt Management Office - DMO) de diversos países, sendo frequentemente utilizado em comparativos internacionais (LEISTER, 2012).

O ATM é calculado conforme a fórmula abaixo:

$$
A T M=\frac{\sum_{t=0}^{n} t \times F P t}{\sum_{t=0}^{n} F P t}
$$

Onde,

FPt: fluxo de principal do título no tempo t;

$t$ : fração ano entre a data de apuração do $A T M$ e a data de vencimento do fluxo.

\subsubsection{Custo médio}

O custo médio mensal é o indicador que demonstra, em termos percentuais, o custo de carregamento da dívida pública no mês analisado, refletindo a variação dos fatores que afetam

o preço dos títulos que compõem a dívida pública (SECRETARIA DO TESOURO NACIONAL, 2015e).

Conforme destacado anteriormente, a missão da gestão da dívida pública é a redução do custo de refinanciamento no longo prazo, mantendo os riscos em níveis prudentes. Esta definição ressalta a importância deste indicador para as finanças públicas de um país, na medida em que significa a remuneração paga pelo Tesouro aos credores por emprestá-lo recursos financeiros ou, em outras palavras, é o preço que a sociedade tem de pagar pelo endividamento público (BONOMO et al., 2003; NETO, 1983). Nesse mesmo sentido, Colbano e Leister (2015) argumentam que uma gestão eficiente da dívida pública permite a redução do seu custo de financiamento, o que permite a ampliação de outras despesas relevantes para o país.

$\mathrm{O}$ conceito de custo refere-se à variação do valor dos títulos em consequência da variação dos índices envolvidos, bem como os pagamentos de juros aos seus detentores. Há, no entanto, diversas maneiras de se calcular o custo do endividamento público, não havendo um procedimento uniforme entre os países (BONOMO et al., 2003).

O cálculo do custo médio mensal de um título, conforme calculado pela Secretaria do Tesouro Nacional atualmente, pode ser demonstrado pela fórmula abaixo. O custo médio mensal da carteira, por sua vez, pode ser obtido pela média ponderada do custo médio mensal de cada título individual (SECRETARIA DO TESOURO NACIONAL, 2015e): 
Em que:

CM: Custo médio mensal do título;

TIR: Taxa interna de retorno média das emissões do título, em \% a.m.;

Variação do indexador: Variação do indexador ou da moeda do título observada no mês.

A maioria dos escritórios de administração de dívida pública mensura o custo financeiro apenas em termos do fluxo futuro de custos nominais do serviço da dívida. Entretanto, para os países que gerenciam ativamente seus portfólios de dívida, os retornos líquidos em suas posições de negociação geralmente são mensurados em termos de mudanças no valor de mercado da carteira de negociação, isto é, as variações nos preços dos títulos que compõem a dívida pública (BANCO MUNDIAL; FUNDO MONETÁRIO INTERNACIONAL, 2014).

Mais uma vez, ressalta-se a vinculação existente entre o método adotado na apuração do estoque e aquele utilizado no cálculo dos demais indicadores da dívida pública. Segundo Medeiros (2003), deve-se considerar a melhor forma de apurar o valor dos passivos para que reflitam seus custos de financiamento de maneira adequada. No que se refere ao custo médio mensal, essa relação se torna ainda mais clara, uma vez que este indicador demonstra a evolução dos preços e os pagamentos dos títulos públicos ao longo do tempo. Nesse sentido, por uma questão de uniformidade metodológica, o cálculo do custo médio, considerando os valores de mercado dos títulos, deve incorporar ao cálculo as flutuações das taxas de mercado, a fim de refletir de maneira fiel as variações nos preços dos títulos ocorridas no período analisado.

Esta revisão da literatura permite verificar a relevância da escolha da metodologia de precificação dos títulos na apuração do estoque da DPF. Desta forma, esta pesquisa tem como objetivo analisar, a partir de um estudo empírico, o impacto de uma possível adoção da marcação a mercado como método de apuração do estoque da dívida pública mobiliária federal, bem como os reflexos nos seus indicadores de custo e risco. 


\section{PROCEDIMENTOS METODOLÓGICOS}

No que se refere aos procedimentos metodológicos adotados, a pesquisa pode ser dividida em duas etapas. A primeira teve como objetivo identificar, por meio da realização de uma pesquisa survey de natureza descritiva, os diferentes métodos de apreçamento dos títulos na apuração do estoque adotados pelos departamentos de dívida pública dos diversos países. A segunda etapa teve como propósito comparar e explicar os resultados obtidos na apuração do estoque da DPF, calculado pelas diferentes metodologias de precificação dos títulos.

\subsection{SURVEY}

O método de pesquisa survey se caracteriza pela coleta de um conjunto de dados quantificáveis, geralmente por meio da aplicação de questionário, com a finalidade de descrever determinados atributos de uma população de interesse (BABBIE, 1999).

Dada a relevância do estoque como indicador de tamanho do endividamento público, como parâmetro para se estabelecer comparativos internacionais e como base para a apuração dos demais indicadores da dívida pública, torna-se fundamental que se aprofunde o entendimento acerca das metodologias de precificação adotadas na sua apuração. Ademais, conhecer a metodologia de cálculo de um indicador é uma condição fundamental para se analisar a sua coerência conceitual e se fazer uma adequada interpretação de seus resultados.

\subsubsection{Amostragem}

Quanto ao critério de escolha dos países participantes, foram incluídos na pesquisa todos os países membros do Banco Mundial, o que caracteriza a amostra como não-probabilística. Desta forma, o levantamento alcançou um total de 183 países, abrangendo as seis regiões geográficas de atuação do Banco Mundial (Africa - AFR; East Asia and Pacific-EAP; Europe and Central Asia - ECA; Latin America and Caribbean - LAC; Middle East and North Africa - MENA; e Southeast Asia-SAR).

\subsubsection{Coleta de dados}

O levantamento foi realizado com o suporte do Departamento de Assessoria Financeira e Produtos Bancários da Tesouraria do Banco Mundial $^{7}$, que tem como atribuições realizar

\footnotetext{
${ }^{7}$ Tradução de The Financial Advisory and Banking Department of the World Bank Treasury.
} 
pesquisas e prestar assistência técnica junto aos departamentos de administração da dívida pública dos diversos países. O convite à participação da pesquisa foi enviado através do $e$-mail institucional do Banco Mundial. Optou-se por utilizar o questionário como instrumento de coleta de dados, aplicado por meio da ferramenta "Surveymonkey". Buscou-se, com essa estratégia, alcançar maior abrangência de países pesquisados e redução no tempo e nos custos da pesquisa.

O questionário, composto por quatro perguntas, está apresentado no apêndice A.

\subsubsection{Análise dos dados}

A análise dos dados por estatística descritiva permitiu traçar um mapeamento internacional entre os escritórios de administração de dívida (Debt Management Office - DMO) dos diversos países quanto às metodologias de precificação dos títulos adotadas na apuração do estoque da dívida pública, segmentando os resultados segundo o nível de desenvolvimento da economia. Os países foram agrupados como: economias avançadas; mercados emergentes e economias de média renda; e países de baixa renda, de acordo com a classificação feita pelo Fundo Monetário Internacional, na publicação Fiscal Monitor - 2016. Os dados obtidos no levantamento foram tabulados e processados por meio do software Excel.

\subsection{ANÁLISE COMPARATIVA ENTRE AS DIFERENTES METODOLOGIAS DE PRECIFICAÇÃO DOS TÍTULOS NA APURAÇÃO DO ESTOQUE DA DPF}

A segunda etapa da pesquisa empírica teve abordagem quantitativa e recorte temporal longitudinal, tendo como propósito comparar a série histórica de preços diários dos títulos públicos que compõem a carteira da DPF apurados pelas diferentes metodologias de precificação. Na sequência, foi realizada a análise das variáveis que explicam as diferenças verificadas entre os preços na curva e os preços de mercado dos títulos públicos no período analisado. Por fim, foi feita a mensuração do impacto gerado nos resultados dos indicadores tradicionais de custo e risco da DPF em função dessas diferentes metodologias de apuração do estoque.

\subsubsection{Amostragem}

Esta análise teve como alvo os títulos públicos de maior liquidez no mercado doméstico, os chamados "títulos de leilão", que compreendem as siglas LTN (Letra do Tesouro Nacional), LFT (Letra Financeira do Tesouro), NTN-B (Nota do Tesouro Nacional-série B) e NTN-F 
(Nota do Tesouro Nacional-série F) e representam aproximadamente $90 \%$ do estoque total da DPF. Quanto à dívida externa, foi analisada toda a carteira de títulos da DPMFe, que é composta pelos bônus do tipo Euro, Global e Global BRL. Com isso, a abrangência alcançada pela pesquisa equivale a $95 \%{ }^{8}$ do total da DPF em mercado.

O Quadro 1 resume as características das siglas da DPMFi analisadas.

Quadro 1 - Características das siglas da dívida interna.

\begin{tabular}{|l|l|l|l|l|l|c|}
\hline Sigla & Indexador & $\begin{array}{l}\text { Prazos de } \\
\text { Emissão }\end{array}$ & \multicolumn{1}{|c|}{ Resgate do Principal } & \multicolumn{1}{|c|}{$\begin{array}{c}\text { Cupom de } \\
\text { Juros }\end{array}$} & $\begin{array}{c}\text { Padrão de } \\
\text { contagem } \\
\text { de dias }\end{array}$ & $\begin{array}{c}\text { Participação } \\
\text { no estoque } \\
\text { da DPF }\end{array}$ \\
\hline LTN & $\begin{array}{l}\text { Não há } \\
\text { (prefixado) }\end{array}$ & Até 4 anos & $\begin{array}{l}\text { Única parcela no vencimento, } \\
\text { pelo valor nominal. }\end{array}$ & Não há & $\begin{array}{l}\text { Dias } \\
\text { úteis/2529 }\end{array}$ & $27,4 \%$ \\
\hline NTN-B & IPCA & $\begin{array}{l}\text { Até } 40 \\
\text { anos }\end{array}$ & $\begin{array}{l}\text { Única parcela no vencimento, } \\
\text { pelo valor nominal } \\
\text { atualizado. }\end{array}$ & $\begin{array}{l}6 \% \text { a.a., pagos } \\
\text { semestralmente }\end{array}$ & $\begin{array}{l}\text { Dias } \\
\text { úteis/252 }\end{array}$ & $29,0 \%$ \\
\hline NTN-F & $\begin{array}{l}\text { Não há } \\
\text { (prefixado) }\end{array}$ & $\begin{array}{l}\text { Até } 10 \\
\text { anos }\end{array}$ & $\begin{array}{l}\text { Única parcela no vencimento, } \\
\text { pelo valor nominal. }\end{array}$ & $\begin{array}{l}10 \% \text { a.a., pagos } \\
\text { semestralmente }\end{array}$ & $\begin{array}{l}\text { Dias } \\
\text { úteis/252 }\end{array}$ & $11,6 \%$ \\
\hline LFT & Selic & Até 5 anos & $\begin{array}{l}\text { Única parcela no vencimento, } \\
\text { pelo valor nominal } \\
\text { atualizado. }\end{array}$ & $\begin{array}{l}\text { Dias } \\
\text { úteis/252 }\end{array}$ & $22,4 \%$ \\
\hline
\end{tabular}

Fonte: Secretaria do Tesouro Nacional, 2015a.

As principais características das siglas da dívida externa estão apresentadas no Quadro

2.

Quadro 2 - Características das siglas da dívida externa.

\begin{tabular}{|l|l|l|l|l|l|}
\hline Siglas & Moeda & \multicolumn{1}{|c|}{ Resgate do Principal } & \multicolumn{1}{|c|}{ Cupom de Juros } & $\begin{array}{c}\text { Padrão de } \\
\text { contagem de } \\
\text { dias }\end{array}$ & $\begin{array}{c}\text { Participação } \\
\text { no estoque } \\
\text { da DPF }^{8}\end{array}$ \\
\hline Global & Dólar & $\begin{array}{l}\text { Única parcela no vencimento, } \\
\text { pelo valor nominal, com } \\
\text { exceção do Global A-Bond, } \\
\text { que amortiza o principal em } \\
18 \text { parcelas semestrais. }\end{array}$ & $\begin{array}{l}\text { Pagos semestralmente por taxas } \\
\text { diversas. }\end{array}$ & $30 / 360^{10}$ & $4,0 \%$ \\
\hline $\begin{array}{l}\text { Global } \\
\text { BRL }\end{array}$ & Real & $\begin{array}{l}\text { Única parcela no vencimento, } \\
\text { pelo valor nominal. }\end{array}$ & $\begin{array}{l}\text { Pagos semestralmente por taxas } \\
\text { diversas. }\end{array}$ & $30 / 360$ & $0,5 \%$ \\
\hline Euro & Euro & $\begin{array}{l}\text { Única parcela no vencimento, } \\
\text { pelo valor nominal. }\end{array}$ & $\begin{array}{l}\text { Pagos anualmente por taxas } \\
\text { diversas. }\end{array}$ & $\begin{array}{l}\text { Dias corridos/ } \\
\text { dias corridos }\end{array}$ & $0,2 \%$ \\
\hline
\end{tabular}

Fonte: Secretaria do Tesouro Nacional, 2015a.

\footnotetext{
${ }^{8}$ Valores extraídos do Relatório Mensal da DPF referente ao mês de dezembro de 2015.

${ }^{9}$ Padrão de contagem que leva em conta os dias úteis e considera o ano com 252 dias (SECRETARIA DO TESOURO NACIONAL, 2003b).

${ }^{10}$ Padrão de contagem de dias que considera o ano com 12 meses de 30 dias cada (SECRETARIA DO TESOURO NACIONAL, 2003a).

${ }^{11}$ Padrão que considera o número de dias corridos na contagem da fração ano (SECRETARIA DO TESOURO NACIONAL, 2003b).
} 
Quanto ao recorte temporal, foram incluídos na pesquisa todos os títulos das siglas acima mencionadas vigentes entre 31 de dezembro de 2010 e 31 de dezembro de 2015, abrangendo, portanto, um período de cinco anos. Ao todo, foram calculadas e analisadas as séries históricas de preços diários de 88 títulos da DPMFi e 32 títulos da DPMFe, os quais estão elencados nos Quadros 3 e 4. Deve-se mencionar que o nome dos títulos é formado pela concatenação de sua sigla e sua data de vencimento.

\section{Quadro 3 - Títulos da DPMFi incluídos na pesquisa}

\begin{tabular}{|l|l|}
\hline Sigla & \multicolumn{1}{|c|}{ Título } \\
\hline & LTN 010111 \\
\hline & LTN 010411 \\
\hline LTN 010711 \\
\hline LTN 011011 \\
\hline LTN 010412 \\
\hline & LTN 010712 \\
\hline LTN 011012 \\
\hline LTN 010113 \\
\hline LTN 010413 \\
\hline LTN 010713 \\
\hline LTN 011013 \\
\hline LTN 010114 \\
\hline LTN 010414 \\
\hline LTN 010714 \\
\hline LTN 011014 \\
\hline LTN 010115 \\
\hline LTN 010415 \\
\hline LTN 010715 \\
\hline LTN 011015 \\
\hline LIN 010116 \\
\hline LTN 010416 \\
\hline LTN 010716 \\
\hline LTN 011016 \\
\hline LTN 010117 \\
\hline LTN 010717 \\
\hline LTN 011017 \\
\hline LTN 010118 \\
\hline LTN 010718 \\
\hline LTN 010119 \\
\hline LTN 010719 \\
\hline
\end{tabular}




\begin{tabular}{|c|c|}
\hline \multirow{11}{*}{ NTN-F } & NTN-F 010111 \\
\hline & NTN-F 010112 \\
\hline & \begin{tabular}{|l|} 
NTN-F 010113 \\
\end{tabular} \\
\hline & NTN-F 010114 \\
\hline & \begin{tabular}{|l|} 
NTN-F 010115 \\
\end{tabular} \\
\hline & NTN-F 010117 \\
\hline & NTN-F 010118 \\
\hline & NTN-F 010119 \\
\hline & \begin{tabular}{|l|} 
NTN-F 010121 \\
\end{tabular} \\
\hline & \begin{tabular}{|l} 
NTN-F 010123 \\
\end{tabular} \\
\hline & NTN-F 010125 \\
\hline \multirow{20}{*}{ NTN-B } & NTN-B 150511 \\
\hline & NTN-B 151111 \\
\hline & \begin{tabular}{|l|} 
NTN-B 150812 \\
\end{tabular} \\
\hline & NTN-B 150513 \\
\hline & \begin{tabular}{|l|} 
NTN-B 150814 \\
\end{tabular} \\
\hline & NTN-B 150515 \\
\hline & \begin{tabular}{|l|} 
NTN-B 150816 \\
\end{tabular} \\
\hline & NTN-B 150517 \\
\hline & \begin{tabular}{|l|} 
NTN-B 150818 \\
\end{tabular} \\
\hline & \begin{tabular}{|l} 
NTN-B 150519 \\
\end{tabular} \\
\hline & \begin{tabular}{|l|} 
NTN-B 150820 \\
\end{tabular} \\
\hline & \begin{tabular}{|l|} 
NTN-B 150822 \\
\end{tabular} \\
\hline & \begin{tabular}{|l|} 
NTN-B 150523 \\
\end{tabular} \\
\hline & \begin{tabular}{|l|} 
NTN-B 150824 \\
\end{tabular} \\
\hline & \begin{tabular}{|l|} 
NTN-B 150830 \\
\end{tabular} \\
\hline & \begin{tabular}{|l} 
NTN-B 150535 \\
\end{tabular} \\
\hline & \begin{tabular}{|l|} 
NTN-B 150840 \\
\end{tabular} \\
\hline & \begin{tabular}{|l|} 
NTN-B 150545 \\
\end{tabular} \\
\hline & NTN-B 150850 \\
\hline & NTN-B 150555 \\
\hline \multirow{27}{*}{ LFT } & LFT 160311 \\
\hline & LFT 150611 \\
\hline & LFT 210911 \\
\hline & LFT 161111 \\
\hline & LFT 211211 \\
\hline & LFT 070312 \\
\hline & LFT 070912 \\
\hline & LFT 211112 \\
\hline & LFT 070313 \\
\hline & LFT 070613 \\
\hline & LFT 070913 \\
\hline & LFT 181213 \\
\hline & LFT 070314 \\
\hline & LFT 070914 \\
\hline & LFT 070315 \\
\hline & LFT 070915 \\
\hline & LFT 010316 \\
\hline & LFT 070916 \\
\hline & LFT 070317 \\
\hline & LFT 070917 \\
\hline & LFT 010318 \\
\hline & LFT 010918 \\
\hline & LFT 010319 \\
\hline & LFT 010320 \\
\hline & LFT 010920 \\
\hline & LFT 010321 \\
\hline & LFT 010921 \\
\hline
\end{tabular}




\section{Quadro 4 - Títulos da DPMFe incluídos na pesquisa}

\begin{tabular}{|c|c|}
\hline Sigla & Título \\
\hline \multirow{5}{*}{ Euro } & Euro 2011 \\
\hline & Euro 2012 \\
\hline & Euro 2015 \\
\hline & Eurolira 2017 \\
\hline & Euro 2021 \\
\hline \multirow{23}{*}{ Global } & Global 2011 \\
\hline & Global 2012 \\
\hline & Global 2013 \\
\hline & Global 2014 \\
\hline & Global 2015 \\
\hline & Global 2017 \\
\hline & Global 2019 \\
\hline & Global 2019-A \\
\hline & Global 2020 \\
\hline & Global 2021 \\
\hline & Global 2023 \\
\hline & \begin{tabular}{|l|} 
Global 2024 \\
\end{tabular} \\
\hline & Global 2024-B \\
\hline & Global 2025 \\
\hline & Global 2025 A \\
\hline & \begin{tabular}{|l|} 
Global 2027 \\
\end{tabular} \\
\hline & Global 2030 \\
\hline & Global 2034 \\
\hline & Global 2037 \\
\hline & Global 2040 \\
\hline & Global 2041 \\
\hline & Global 2045 \\
\hline & Global A-Bond 2018 \\
\hline \multirow{4}{*}{ Global BRL } & Global BRL 2016 \\
\hline & Global BRL 2022 \\
\hline & Global BRL 2024 \\
\hline & \begin{tabular}{|l|} 
Global BRL 2028 \\
\end{tabular} \\
\hline
\end{tabular}

\subsubsection{Coleta de dados}

No que se refere à coleta dos dados empíricos, foram utilizadas informações extraídas de relatórios oficiais e diferentes bancos de dados. A apuração dos preços de mercado da DPMFi foi realizada a partir das taxas indicativas dos títulos públicos no mercado secundário divulgadas pela Associação Brasileira das Entidades dos Mercados Financeiro e de Capitais Anbima.

As taxas indicativas representam as taxas avaliadas pela instituição como referência de preço justo de negócio para cada vencimento, de acordo com suas curvas individuais, 
independentemente de ter havido negócio no mercado secundário no decorrer do dia (ANBIMA, 2013).

O cálculo da taxa indicativa é feito pela média aritmética simples das taxas informadas, resultantes do processo de coleta entre as instituições participantes solicitadas pela Anbima a fornecer preços e taxas de títulos públicos federais. Deve-se destacar que as taxas informadas passam por um processo de filtragem com o objetivo de eliminar possíveis inconsistências, como erro no formato da taxa ou tentativas de manipulação das informações (ANBIMA, 2013).

A DPMFe, por sua vez, teve seus títulos precificados pelas taxas médias (Mid yield), que são apuradas diariamente pela média aritmética entre as taxas de retorno referentes aos preços das ofertas de compra (Bid yield) e as taxas de retorno referentes aos preços das ofertas de venda (Ask yield) dos títulos públicos praticadas pelas instituições, tendo como fonte o banco de dados da Bloomberg.

No que se refere aos preços diários dos títulos apurados na curva e às quantidades dos títulos em mercado, foi utilizada a base de dados do Sistema Integrado da Dívida - SID, de responsabilidade da Secretaria do Tesouro Nacional. Já as séries históricas de prazo médio e ATM foram coletadas do Relatório Mensal da Dívida Pública Federal referente ao mês de dezembro de 2015, enquanto os resultados dos demais indicadores foram calculados com base nos dados coletados.

\subsubsection{Análise dos dados}

3.2.3.1 Mensuração das diferenças apuradas entre as séries de preços de mercado e preços na curva dos títulos públicos

O primeiro objetivo desta análise foi quantificar as diferenças entre as séries de preços pela curva, conforme calculado e divulgado pela Secretaria do Tesouro Nacional, e a série de preços de mercado dos títulos da dívida pública. Isso possibilita medir o efeito das alterações nas taxas de mercado sobre o estoque da dívida pública federal brasileira e verificar se a precificação pela curva representa uma boa aproximação do valor de mercado dos títulos, conforme vê-se a seguir.

A questão foi analisada com a utilização do erro quadrático médio (mean squared error - MSE), que é descrito como o somatório do quadrado das diferenças entre os valores estimados e reais, dividido pelo número de termos da série. Este indicador é utilizado para expressar a acurácia de um estimador, sendo tanto melhor quanto mais próximo de zero for seu resultado. 
Este indicador é também usado para mensurar a diferença média entre duas séries de valores (HYNDMAN; KOEHLER, 2006).

Nesse sentido, o erro quadrático médio dos preços na curva em relação aos preços de mercado dos títulos públicos foi calculado pela seguinte fórmula:

$$
M S E=\frac{1}{N} \sum_{t=1}^{n}\left(\frac{X t c-X t m}{X t m}\right)^{2}
$$

Onde:

$X t c$ : valor na curva do título observado no tempo t;

Xtm: valor de mercado do título observado no tempo t;

$N$ : número de pares de valores.

Uma vez que os valores observados do preço na curva podem ser superiores ou inferiores aos valores de mercado, dependendo da variação das taxas de juros no período observado, o erro quadrático se mostra adequado para mensurar a distância entre os valores de mercado e na curva, evitando que os erros positivos e negativos se anulem e distorçam o resultado.

A escolha pela utilização das diferenças percentuais se deve ao fato de os títulos da dívida pública apresentarem preços unitários em ordens de grandeza diferentes. O cálculo do erro em unidades monetárias geraria resultados de difícil comparabilidade. $\mathrm{O}$ erro percentual, por sua vez, tem a vantagem de apresentar resultado adimensional (HYNDMAN, KOEHLER, 2006). Desta forma, optou-se pela apuração da diferença percentual média entre as séries de preços de mercado e na curva dos títulos no período analisado.

Por fim, calculou-se a raiz quadrada erro quadrático médio (root mean squared error $R M S E$ ). Este indicador tem a vantagem de apresentar o resultado na mesma dimensão da variável analisada, o que facilita a interpretação dos resultados (HYNDMAN, KOEHLER, 2006). Desta forma, o RMSE representa a diferença percentual média entre os preços na curva e os preços de mercado dos títulos públicos.

$$
R M S E=\sqrt{M S E}
$$




\subsubsection{Análise de regressão linear múltipla}

Na sequência da mensuração do RMSE de cada um dos títulos, uma nova análise foi realizada com o objetivo de identificar as variáveis que explicam as diferenças apuradas entre os preços na curva e os preços de mercado dos títulos públicos no período analisado.

Essa etapa foi realizada por meio de uma análise de regressão múltipla, tendo como variável dependente o RMSE do preço na curva em relação ao preço de mercado.

A análise de regressão é caracterizada pelo estudo da dependência de uma determinada variável, chamada de variável dependente, em relação a uma ou mais variáveis, chamadas variáveis explicativas, com o objetivo de verificar a intensidade e o grau de associação linear entre essas variáveis (GUJARATI, 2000).

Como variáveis explicativas do modelo, foram utilizados o desvio padrão das taxas de mercado no período analisado em relação à primeira taxa de emissão dos títulos e a duration dos títulos no início do estudo. Ademais, foram incluídas como variáveis dummy os indexadores dos títulos, que representam características intrínsecas dos títulos.

A análise de regressão múltipla foi realizada com a utilização do programa EViews.

Uma importante hipótese do modelo clássico de regressão linear é que a variância de cada termo de perturbação permanece constante, hipótese conhecida como homoscedasticidade. Outra relevante hipótese se refere à não correlação serial entre as perturbações (GUJARATI, 2000). Entretanto, é comum em estudos de séries temporais que os dados apresentem algum grau de heteroscedasticidade e/ou autocorrelação.

A heteroscedasticidade ocorre quando o primeiro postulado supracitado do modelo clássico não é observado, ou seja, a variância condicional da variável dependente não é igual para todas as observações (GUJARATI, 2000).

Já a autocorrelação é caracterizada pela presença de correlação entre membros de séries de observações ordenadas no tempo, como em séries temporais, ou no espaço (cross-section). O modelo clássico de regressão linear pressupõe que as perturbações não apresentem esse comportamento (GUJARATI, 2000).

Os problemas de inferência causados por autocorrelação são similares àqueles decorrentes da heteroscedasticidade (GREENE, 2003). Tanto na presença de autocorrelação como de heteroscedasticidade, os estimadores usuais de mínimos quadrados ordinários, embora não-viesados, já não possuem variância mínima entre todos os estimadores lineares nãoviesados, tornando-se ineficientes (GUJARATI, 2000). 
Em virtude de a amostra apresentar indícios de heteroscedasticidade e autocorrelação, o modelo foi estimado usando matriz robusta de covariância de Newey-West, o qual representa um estimador utilizado para melhorar os parâmetros estimados pelo método de mínimos quadrados nos modelos de regressão em que os resíduos apresentam essas características (GREENE, 2003).

No que se refere à análise individual das variáveis explicativas do modelo, a relação com o RMSE foi testada pelo valor $p$ (valor da probabilidade), que representa a probabilidade de se obter um valor da estatística de teste igual ou superior àquele obtido no estudo (GREENE, 2003; GUJARATI, 2000).

A significância global do modelo de regressão foi verificada pelo teste $\mathrm{F}$, o qual determina se a relação proposta entre a variável dependente e o conjunto de preditores é estatisticamente confiável e o modelo pode ser útil para explicar o comportamento da variável dependente (GUJARATI, 2000). O nível de significância $\alpha$ estabelecido foi de 5\%, valor usualmente convencionado para esse tipo de análise (GREENE, 2003). Isso significa que o nível de confiança do teste é de $95 \%$ (1- $\alpha$ ). Essa definição possibilita a realização de teste de hipótese, em que:

$\mathrm{H}_{0}$ : modelo não é válido para explicar o RMSE;

$\mathrm{H}_{1}$ : modelo é válido para explicar o RMSE.

Caso o valor do teste $\mathrm{F}$ seja inferior ao valor estabelecido para o $\alpha$, há evidência estatística para rejeitar a hipótese nula, isto é, pode-se afirmar, com nível de confiança de 95\%, que o modelo é útil para explicar o RMSE do preço na curva em relação ao preço de mercado dos títulos públicos.

O Coeficiente Múltiplo de Determinação $\mathrm{R}^{2}$ é o indicador que mensura a proporção da variação da variável dependente explicada conjuntamente pela variação dos regressores incluídos no modelo (GREENE, 2003; GUJARATI, 2000). Ainda segundo os autores, conforme são acrescidas variáveis explicativas no modelo, aumenta-se o $\mathrm{R}^{2}$. Nesse sentido, a utilização do $\mathrm{R}^{2}$ Ajustado se justifica por esse indicador se mostrar mais adequado para comparar diferentes modelos que tenham a mesma variável dependente, porém com número diferente de regressores.

Foram analisadas, adicionalmente, medidas alternativas de ajuste: os critérios de informação de Akaike, de Schwarz e de Hannan-Quinn. Esses critérios, como expõem Greene (2003) e Gujarati (2000), são utilizados com frequência para julgar e comparar a adequação de diferentes modelos de regressão. 
3.2.3.3 Mensuração do impacto das diferentes metodologias de precificação nos indicadores de custo e risco na dívida pública

A fase seguinte do estudo empírico teve o propósito de mensurar o impacto das diferentes metodologias de precificação dos títulos nos indicadores tradicionais de custo e risco da dívida pública federal brasileira.

As diferenças entre os resultados encontrados a partir dos diferentes métodos de precificação dos títulos foram mensuradas de maneira análoga àquela utilizada para a série de preços, por meio do RMSE. Pretendeu-se, desta forma, avaliar os reflexos gerados nos indicadores em função das diferentes metodologias de apreçamento adotadas. Quanto à periodicidade, os resultados foram apurados ao final de cada mês durante o período analisado, seguindo a periodicidade com que os indicadores são regularmente calculados e divulgados pelos órgãos competentes.

No comparativo entre o prazo médio, a duration e o ATM, foram considerados os valores agregados das siglas. Deve-se ressaltar que para os títulos bullet, os quais não possuem fluxos de pagamento de cupom de juros, o cálculo dos diferentes indicadores de maturidade de cada título geram resultados iguais, mas seus pesos relativos para o cálculo do resultado da sigla mudam. Assim, a análise dos resultados agregados das siglas se mostra mais adequada, raciocínio que se aplica também à composição da dívida pública.

Ainda sobre a comparação entre os resultados obtidos a partir das diferentes metodologias de cálculo, é importante destacar que o root mean squared error dos indicadores composição e custo médio foram mensurados em pontos percentuais. Por se tratarem de indicadores cujo resultado é expresso em termos percentuais, optou-se por apurar a distância entre os resultados gerados pelas duas metodologias pela subtração, o que resultou em valores em pontos percentuais. 


\section{RESULTADOS}

\subsection{SURVEY}

O questionário foi aplicado a todos os 183 países membros do Banco Mundial. Deste total, foram obtidas 44 respostas completas, por meio das quais foi possível traçar um painel internacional dos escritórios de administração de dívida pública acerca das metodologias de precificação dos títulos adotadas na apuração do estoque da dívida pública. A tabela completa com as respostas fornecidas está apresentada no apêndice B.

Os resultados foram agrupados segundo o nível de desenvolvimento econômico dos países. O Quadro 5 lista os países que responderam ao questionário, segundo esta classificação.

\section{Quadro 5 - Países que responderam ao questionário, por nível de desenvolvimento} econômico

\begin{tabular}{|c|}
\hline Economias avançadas \\
\hline Austrália \\
\hline Áustria \\
\hline Canadá \\
\hline Dinamarca \\
\hline EUA \\
\hline França \\
\hline Holanda \\
\hline Itália \\
\hline Japão \\
\hline Lituânia \\
\hline Suécia \\
\hline Mercados emergentes e economias de média renda \\
\hline África do Sul \\
\hline Argentina \\
\hline Bulgária \\
\hline Chile \\
\hline Colômbia \\
\hline Filipinas \\
\hline Hungria \\
\hline Índia \\
\hline Marrocos \\
\hline México \\
\hline República Dominicana \\
\hline Sérvia \\
\hline Sri Lanka \\
\hline Turquia \\
\hline Ucrânia \\
\hline
\end{tabular}




\begin{tabular}{|c|}
\hline Uruguai \\
\hline Países de baixa renda \\
\hline Antígua e Barbuda \\
\hline Armênia \\
\hline Burkina Faso \\
\hline Camboja \\
\hline Etiópia \\
\hline Gâmbia \\
\hline Georgia \\
\hline Madagascar \\
\hline Maldivas \\
\hline Moldávia \\
\hline Nicarágua \\
\hline Papua Nova Guiné \\
\hline Quirguistão \\
\hline Depública Democrática do Congo \\
\hline Tanzânia \\
\hline Uganda \\
\hline Zâmbia \\
\hline
\end{tabular}

Fonte: Autor, 2016.

Quanto ao método de precificação dos títulos na apuração e divulgação do estoque da dívida pública, somente um país (2\% do total) relatou apurar e divulgar o estoque da dívida pública apenas pelo valor de mercado dos títulos, enquanto 36 países (82\% do total) informaram apurar e divulgar o estoque da dívida pública mobiliária apenas pelo valor nominal ou de face dos títulos. Seis países (14\% do total) declararam apurar e divulgar o estoque tanto pelos valores nominais quanto pelos valores de mercado dos títulos e um país, por outro lado, declarou não possuir dívida mobiliária, apenas dívida contratual.

Desta forma, sete dos 44 países que responderam ao questionário (16\%) declararam apurar e divulgar o estoque da dívida pública mobiliária por seu valor de mercado, como mostra o Gráfico 1. 


\section{Gráfico 1 - Metodologia de precificação dos títulos na apuração e divulgação do estoque} da dívida pública adotada pelos países

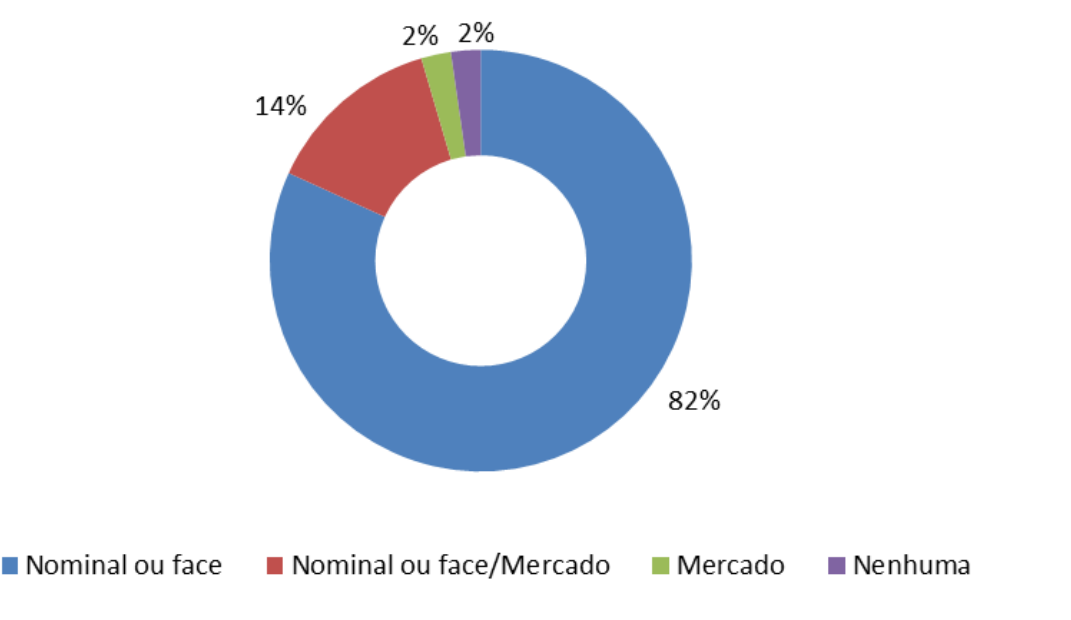

Fonte: Autor, 2016.

A segmentação dos países quanto ao nível de desenvolvimento da economia permitiu o aprofundamento da análise acerca das metodologias de apuração de estoque da dívida pública, gerando resultados para três grandes grupos de países, classificados em: economias avançadas; mercados emergentes e economias de média renda; e países de baixa renda, segundo classificação do Fundo Monetário Internacional de 2016. O Gráfico 2 mostra que 27\% dos países classificados como economias avançadas (3 de 11) afirmaram apurar e divulgar a dívida pública por seus valores de mercado. Foram eles: Austrália, Dinamarca e Suécia.

\section{Gráfico 2 - Metodologia de precificação dos títulos na apuração e divulgação do estoque} da dívida pública adotada pelos países de economia avançada

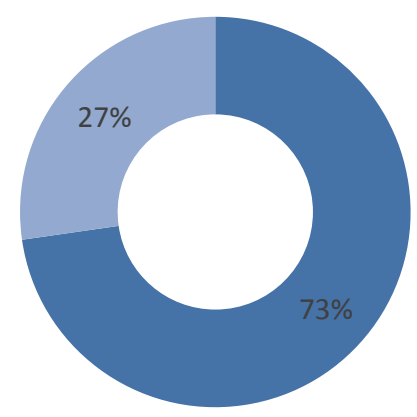

- Nominal ou face Nominal ou face/Mercado

Fonte: Autor, 2016. 
No grupo de países considerados como economias emergentes, Marrocos e Turquia declararam apurar e divulgar a dívida pública por seus valores de mercado, o que representa $13 \%$ dos países que formam esse grupo. No conjunto formado pelos países considerados de baixa renda, essa parcela foi de apenas 12\% (Nicarágua e Papua Nova, em 17 países), o que revela, no universo de países que responderam à pesquisa, uma maior frequência na produção das estatísticas oficiais do estoque da dívida pública em valores de mercado por países classificados como economias avançadas.

Gráfico 3 - Metodologia de precificação dos títulos na apuração e divulgação do estoque da dívida pública adotada pelos mercados emergentes e economias de média renda

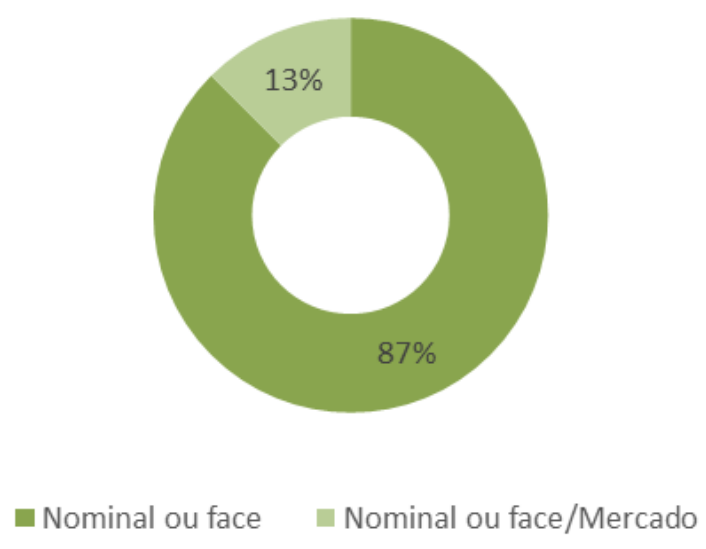

Fonte: Autor, 2016.

Gráfico 4 - Metodologia de precificação dos títulos na apuração e divulgação do estoque da dívida pública adotada pelos países de baixa renda

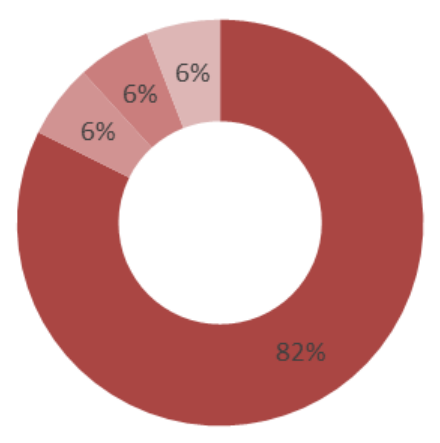

- Nominal ou face $\quad$ Nominal ou face/Mercado Mercado $\quad$ Nenhuma

Fonte: Autor, 2016. 
Dentre os países que declararam divulgar apenas o valor nominal ou valor de face dos títulos ou não possuem essa modalidade de endividamento, nove países (24\% do total) responderam ter a intenção de adotar a marcação a mercado como metodologia oficial de apuração do estoque, enquanto 28 países (76\% do total) responderam não ter essa intenção (Gráfico 5).

\section{Gráfico 5 - Participação de países que pretendem adotar a marcação a mercado como metodologia oficial de apuração do estoque da dívida pública}

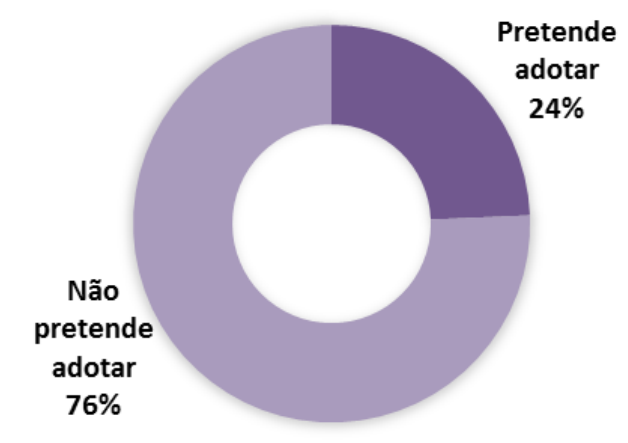

Fonte: Autor, 2016.

Embora apenas $16 \%$ dos países que responderam ao questionário tenham declarado realizar a apuração e divulgação do estoque da dívida pública mobiliária pelos valores de mercado, os resultados mostraram que 22 países (50\% do total) declararam utilizar o valor de mercado dos títulos da dívida pública como informação relevante para o gerenciamento da dívida pública. Por outro lado, outros 22 países declararam não utilizar esta informação, como mostra o Gráfico 6. 
Gráfico 6 - Participação de países que utiliza o valor de mercado da dívida pública no gerenciamento da dívida pública

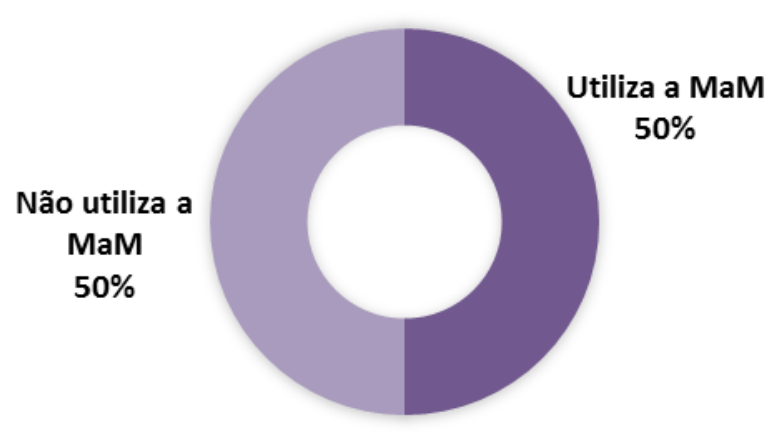

Fonte: Autor, 2016.

A seção seguinte apresenta os resultados obtidos a partir do cálculo da série de preços de mercado e na curva dos títulos das dívidas interna e externa do governo federal em mercado, elencados nas Tabelas 1 e 2, respectivamente, assim como as fórmulas de cálculo específicas que caracterizam cada sigla.

\subsection{ANÁLISE COMPARATIVA ENTRE AS DIFERENTES METODOLOGIAS DE PRECIFICAÇÃO DOS TÍTULOS NA APURAÇÃO DO ESTOQUE DA DPF}

\subsubsection{Dívida Pública Mobiliária Federal interna - DPMFi}

A Tabela 1 mostra de forma sintetizada os resultados do root mean squared error $R M S E$ do preço na curva em relação ao valor de mercado encontrados para cada um dos títulos da Dívida Pública Federal Mobiliária interna - DPMFi. 
Tabela 1 - Resultados da DPMFi, por título

\begin{tabular}{|c|c|c|}
\hline Sigla & Título & RMSE curva \\
\hline \multirow{31}{*}{$\begin{array}{c}\text { LTN } \\
\text { (prefixado) }\end{array}$} & LTN 010111 & $0,00 \%$ \\
\hline & LTN 010411 & $0,05 \%$ \\
\hline & LTN 010711 & $0,25 \%$ \\
\hline & LTN 011011 & $0,21 \%$ \\
\hline & LTN 010412 & $0,35 \%$ \\
\hline & LTN 010712 & $0,69 \%$ \\
\hline & LTN 011012 & $0,62 \%$ \\
\hline & LTN 010113 & $1,47 \%$ \\
\hline & LTN 010413 & $2,12 \%$ \\
\hline & LTN 010713 & $2,89 \%$ \\
\hline & LTN 011013 & $0,18 \%$ \\
\hline & LTN 010114 & $2,64 \%$ \\
\hline & LTN 010414 & $1,85 \%$ \\
\hline & LTN 010714 & $0,93 \%$ \\
\hline & LTN 011014 & $0,35 \%$ \\
\hline & LTN 010115 & $4,00 \%$ \\
\hline & LTN 010415 & $2,03 \%$ \\
\hline & LTN 010715 & $1,37 \%$ \\
\hline & LTN 011015 & $0,37 \%$ \\
\hline & LTN 010116 & $2,73 \%$ \\
\hline & LTN 010416 & $0,72 \%$ \\
\hline & LTN 010716 & $4,94 \%$ \\
\hline & LTN 011016 & $1,49 \%$ \\
\hline & LTN 010117 & $4,88 \%$ \\
\hline & LTN 010717 & $2,22 \%$ \\
\hline & LTN 011017 & $2,36 \%$ \\
\hline & LTN 010118 & $2,95 \%$ \\
\hline & LTN 010718 & $4,63 \%$ \\
\hline & LTN 010119 & $5,13 \%$ \\
\hline & LTN 010719 & $5,61 \%$ \\
\hline & LTN & $2,09 \%$ \\
\hline \multirow{12}{*}{$\begin{array}{c}\text { NTN-F } \\
\text { (prefixado) }\end{array}$} & NTN-F 010111 & $0,00 \%$ \\
\hline & NTN-F 010112 & $0,26 \%$ \\
\hline & NTN-F 010113 & $1,43 \%$ \\
\hline & NTN-F 010114 & $3,52 \%$ \\
\hline & NTN-F 010115 & $3,61 \%$ \\
\hline & NTN-F 010117 & $4,78 \%$ \\
\hline & NTN-F 010118 & $6,42 \%$ \\
\hline & NTN-F 010119 & $6,10 \%$ \\
\hline & NTN-F 010121 & $6,82 \%$ \\
\hline & NTN-F 010123 & $9,39 \%$ \\
\hline & NTN-F 010125 & $7,49 \%$ \\
\hline & NTN-F & $5,16 \%$ \\
\hline
\end{tabular}


(continuação)

\begin{tabular}{|c|c|c|}
\hline Sigla & Título & RMSE curva \\
\hline \multirow{28}{*}{$\begin{array}{c}\text { LFT } \\
\text { (taxa flutuante) }\end{array}$} & LFT 160311 & $0,00 \%$ \\
\hline & LFT 150611 & $0,00 \%$ \\
\hline & LFT 210911 & $0,00 \%$ \\
\hline & LFT 161111 & $0,00 \%$ \\
\hline & LFT 211211 & $0,00 \%$ \\
\hline & LFT 070312 & $0,00 \%$ \\
\hline & LFT 070912 & $0,02 \%$ \\
\hline & LFT 211112 & $0,01 \%$ \\
\hline & LFT 070313 & $0,02 \%$ \\
\hline & LFT 070613 & $0,02 \%$ \\
\hline & LFT 070913 & $0,03 \%$ \\
\hline & LFT 181213 & $0,04 \%$ \\
\hline & LFT 070314 & $0,04 \%$ \\
\hline & LFT 070914 & $0,05 \%$ \\
\hline & LFT 070315 & $0,07 \%$ \\
\hline & LFT 070915 & $0,07 \%$ \\
\hline & LFT 010316 & $0,09 \%$ \\
\hline & LFT 070916 & $0,10 \%$ \\
\hline & LFT 070317 & $0,12 \%$ \\
\hline & LFT 070917 & $0,13 \%$ \\
\hline & LFT 010318 & $0,13 \%$ \\
\hline & LFT 010918 & $0,10 \%$ \\
\hline & LFT 010319 & $0,06 \%$ \\
\hline & LFT 010320 & $0,06 \%$ \\
\hline & LFT 010920 & $0,01 \%$ \\
\hline & LFT 010321 & $0,08 \%$ \\
\hline & LFT 010921 & $0,01 \%$ \\
\hline & LFT & $0,05 \%$ \\
\hline \multirow{16}{*}{$\begin{array}{c}\text { NTN-B } \\
\text { (índice de preços) }\end{array}$} & NTN-B 150511 & $1,05 \%$ \\
\hline & NTN-B 151111 & $0,37 \%$ \\
\hline & NTN-B 150812 & $1,26 \%$ \\
\hline & NTN-B 150513 & $2,92 \%$ \\
\hline & NTN-B 150814 & $4,06 \%$ \\
\hline & NTN-B 150515 & $6,24 \%$ \\
\hline & NTN-B 150816 & $3,36 \%$ \\
\hline & NTN-B 150517 & $6,57 \%$ \\
\hline & NTN-B 150818 & $5,06 \%$ \\
\hline & NTN-B 150519 & $1,92 \%$ \\
\hline & NTN-B 150820 & $7,22 \%$ \\
\hline & NTN-B 150822 & $8,82 \%$ \\
\hline & NTN-B 150523 & $3,54 \%$ \\
\hline & NTN-B 150824 & $12,32 \%$ \\
\hline & NTN-B 150830 & $9,23 \%$ \\
\hline & NTN-B 150535 & $15,29 \%$ \\
\hline
\end{tabular}


(conclusão)

\begin{tabular}{clc}
\hline Sigla & Título & RMSE curva \\
\hline & NTN-B 150840 & $13,96 \%$ \\
NTN-B & NTN-B 150545 & $17,46 \%$ \\
(índice de preços) & NTN-B 150850 & $14,58 \%$ \\
& NTN-B 150555 & $7,98 \%$ \\
& NTN-B & $\mathbf{7 , 9 9 \%}$ \\
\hline
\end{tabular}

Fonte: Autor, 2016.

A análise dos resultados, resumidos na Tabela 1, indica a existência de diferentes variações entre as séries de preços de mercado e na curva, de acordo com as características de cada título.

As diferenças entre os valores de mercado e os valores na curva e nominais apurados no estudo empírico derivam das alterações das condições de mercado que geram flutuações das taxas de rentabilidade dos títulos públicos.

Como consequência destas variações, ocorre um descolamento do valor de mercado, precificado pelas taxas de mercado, em relação ao valor na curva, precificado pela taxa média das emissões de cada título. Esses preços são afetados de forma distinta de acordo com as características dos títulos, tendo maior sensibilidade às alterações das taxas quanto maior for a maturidade de seus vencimentos.

As Letras Financeiras do Tesouro - LFT, por serem indexadas à taxa Selic, que tem repactuação diária, apresentam variações pouco significativas na taxa de emissão ao longo do tempo, que permanecem próximas de zero. Isso explica a proximidade entre os valores de mercado e na curva, explicitada pelo RMSE agregado da sigla de $0,05 \%$.

As Letras do Tesouro Nacional - LTN, títulos prefixados sem pagamento de cupom de juros, apresentaram RMSE agregado da sigla de 2,09\%, sendo a LTN 010719, que tem o prazo de vencimento mais alongado entre as LTN, aquela que apresentou o maior RMSE $(5,61 \%)$. Apesar da intensa flutuação das taxas de juros no período, o reduzido RMSE da sigla pode ser explicado pelo prazo de maturidade mais curto destes títulos em relação ao prazo de maturidade dos títulos das demais siglas.

Em relação aos títulos com pagamento semestral de cupom de juros, as séries de preços de mercado e na curva das Notas do Tesouro Nacional-série F - NTN-F tiveram RMSE de $5,16 \%$, refletindo a volatilidade das taxas de rentabilidade deste título no período estudado. Já as Notas do Tesouro Nacional-série B - NTN-B, indexadas ao IPCA, apresentaram o maior RMSE agregado entre os títulos da dívida pública federal interna (7,99\%), o que pode ser explicado pela flutuação das taxas de mercado e pelo prazo de vencimento mais alongado destes 
papéis em relação aos demais títulos da DPF, que torna o preço desses títulos mais sensível às variações das taxas de juros.

A partir da próxima seção, passa-se a analisar individualmente alguns dos títulos incluídos no estudo visando aprofundar a investigação a respeito do comportamento dos preços de mercado, pela curva e os valores nominais dos títulos ao longo do tempo. Os gráficos mostram, ainda, no eixo secundário, a diferença percentual entre os preços de mercado e na curva. Adicionalmente, são apresentadas as trajetórias das taxas de mercado de cada título no período analisado

\section{LTN}

A precificação das LTN se dá pela seguinte fórmula:

Preço Unitário $=$ cotação $x$ VNA $=\frac{1}{(1+i)^{\frac{d u}{252}}} \times 1.000$

Onde:

$d u$ : representa o número de dias úteis entre a data de apuração do preço (inclusive) e a data de vencimento do fluxo do título (exclusive).

$i$ : na precificação pela curva, trata-se da taxa interna de retorno média das emissões, o que é matematicamente equivalente a precificar cada emissão pela sua própria TIR até o vencimento do título; na precificação a valor de mercado, trata-se da taxa pelo qual o título está sendo negociado na data da precificação.

\section{LTN 010714}

A evolução dos preços da LTN 010714, desde sua primeira emissão, pode ser visualizada no Gráfico 7, enquanto o Gráfico 8 mostra o comportamento da taxa de mercado do título ao longo do período analisado. 
Gráfico 7 - Preços de mercado e na curva da LTN 010714.

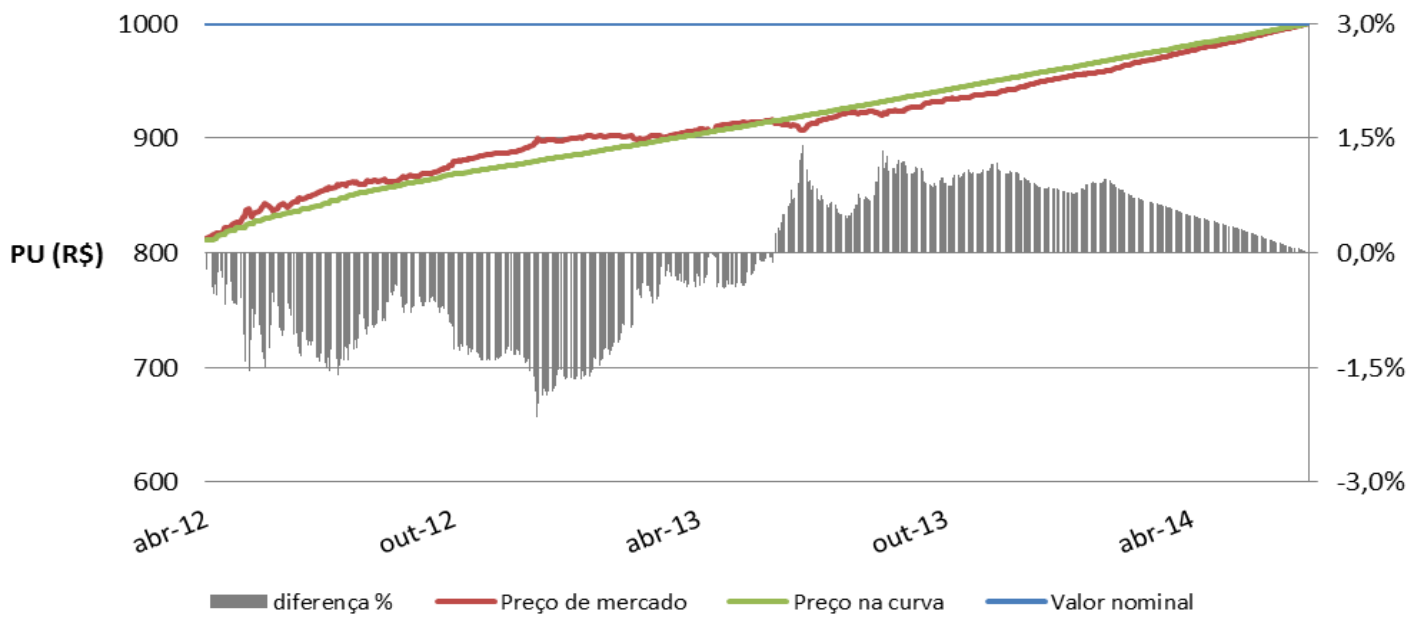

Fonte: Autor, 2016.

$\mathrm{RMSE}=\mathbf{0 , 9 3 \%}$

Gráfico 8 - Taxas de mercado da LTN 010714

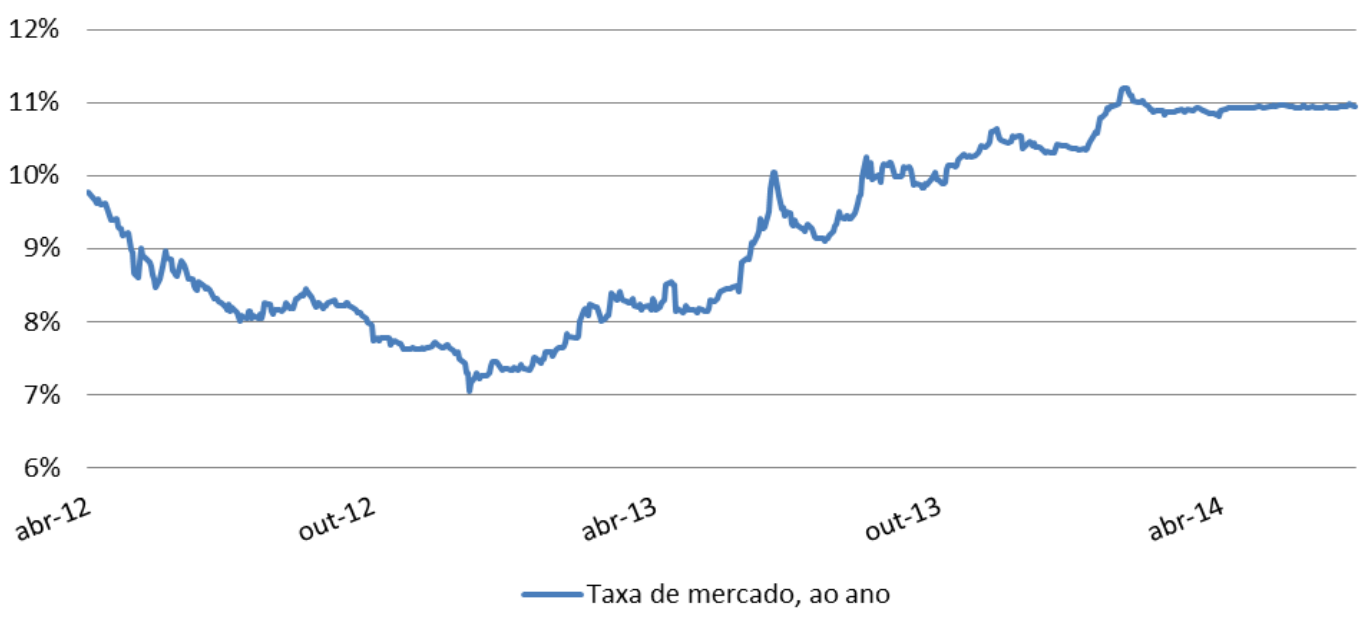

Fonte: Anbima.

As trajetórias dos preços de mercado e na curva se iniciam do mesmo ponto, uma vez que as emissões são realizadas sob as condições de mercado. Após a primeira emissão, em abril de 2012, as taxas apresentaram redução, provocando um aumento nos preços de mercado em relação aos preços na curva. Essa relação se inverte a partir de 2013, quando as taxas de mercado se elevaram, reduzindo os preços de mercado para níveis abaixo do preço na curva.

Deve-se destacar que o preço na curva é afetado marginalmente pelas alterações na taxa de mercado à medida que novas emissões são realizadas. Isso pode ser percebido pela 
aproximação das duas linhas no início de suas trajetórias, período em que se concentraram as emissões desse título. No período final da série, pode-se observar que o preço de mercado permanece abaixo do preço na curva com uma trajetória mais comportada, o que pode ser explicado pela aproximação da data de vencimento do título e pela redução da volatilidade das taxas de rentabilidade, como visto no Gráfico 8.

\section{LTN 010116}

As séries de preços da LTN 010116 apresentaram o mesmo padrão de comportamento observado na LTN 010714, o que é justificado pela proximidade entre suas primeiras emissões. Entretanto, o distanciamento entre as linhas que marcam os preços de mercado e na curva é mais acentuado na LTN 010116, que apresentou maior flutuação das taxas no período analisado (entre 7,9\% a.a. e 14,7\% a.a.), além de possuir um prazo de vencimento mais alongado, o que torna seus preços de mercado mais sensíveis a tais flutuações. Isso explica o RMSE de 2,73\%, mais elevado que o RMSE encontrado na LTN 010714, de 0,93\%.

Assim como na LTN 010714, é possível perceber que a trajetória dos preços na curva é também afetada pelas novas emissões do título, fazendo com que o preço na curva se aproxime do preço de mercado. A partir do último leilão do título, em setembro de 2013, observa-se que o preço pela curva passa a ter uma trajetória mais previsível, variando apenas em função da aproximação da data de vencimento do papel.

Gráfico 9 - Preços de mercado e na curva da LTN 010116.

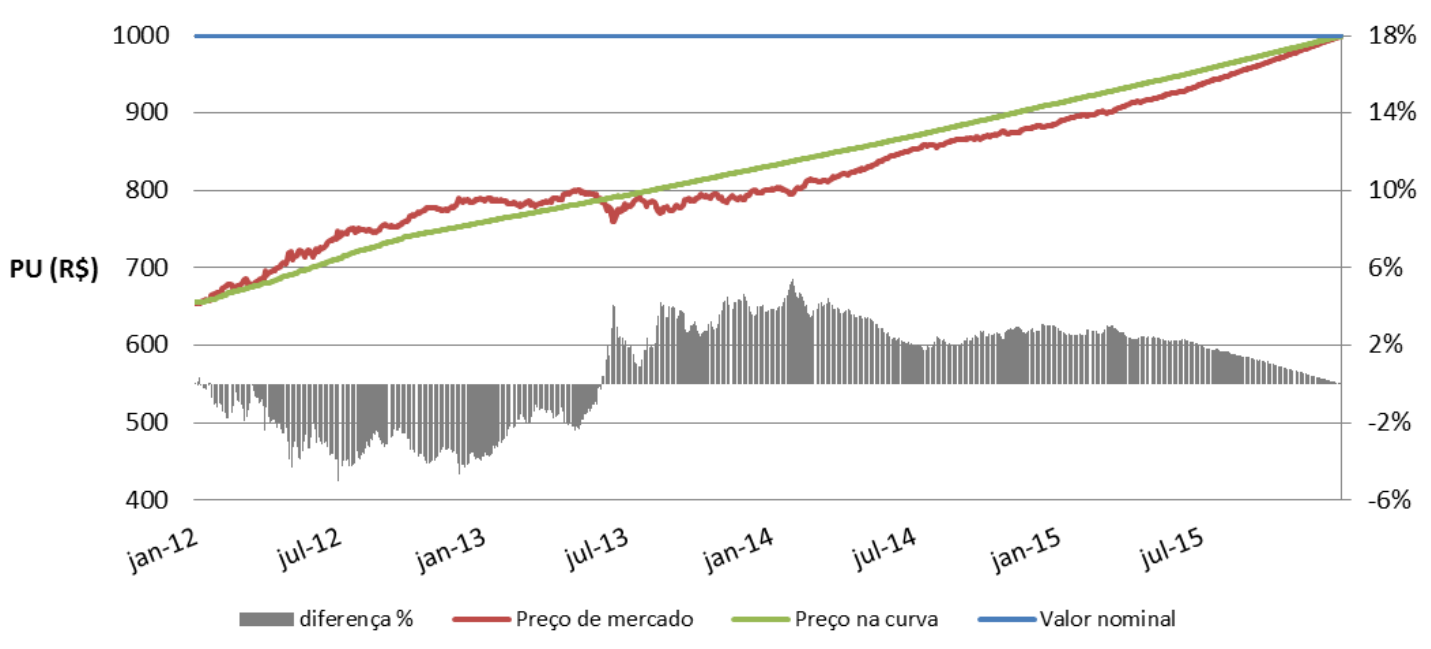

Fonte: Autor, 2016. 
RMSE $=\mathbf{2 , 7 3 \%}$

Gráfico 10 - Taxas de mercado da LTN 010116.

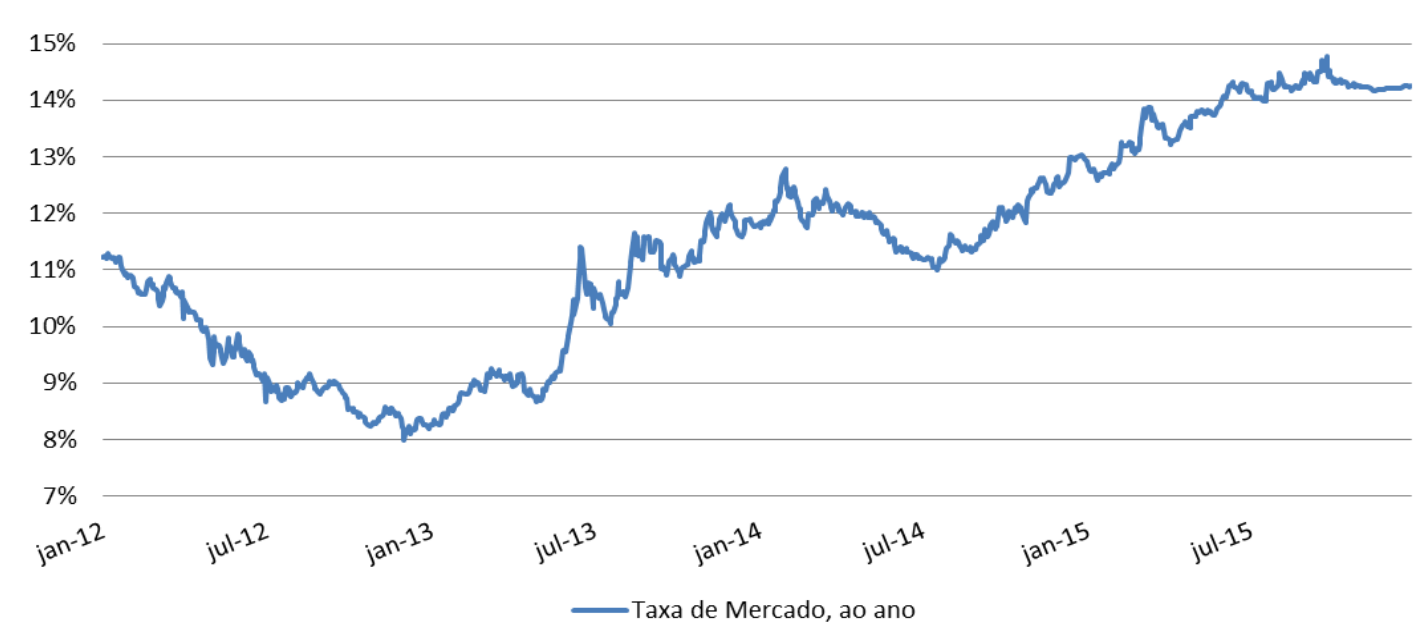

Fonte: Anbima.

\section{NTN-F}

Abaixo está apresentada a fórmula de precificação das NTN-F.

$$
P U=\operatorname{cotação~} x V N A=\left[\left[\frac{(1+\text { cupom })^{0,5}-1}{(1+i)^{\frac{d u 1}{252}}}\right]+\left[\frac{(1+\text { cupom })^{0,5}-1}{(1+i)^{\frac{d u 2}{252}}}\right]+\ldots+\left[\frac{(1+\text { cupom })^{0,5}}{(1+i)^{\frac{d u n}{252}}}\right]\right] \times 1.000
$$

Onde:

$d u$ : representa o número de dias úteis entre a data de apuração do preço (inclusive) e a data de vencimento do fluxo do título (exclusive).

$i$ : na precificação pela curva, trata-se da taxa interna de retorno média das emissões, o que é matematicamente equivalente a precificar cada emissão pela sua própria TIR até o vencimento do título; na precificação a valor de mercado, trata-se da taxa pelo qual o título está sendo negociado na data da precificação.

cupom: taxa que determina os fluxos periódicos de pagamento de juros (\% a.a.). Nas NTN-F, essa taxa é de $10 \%$ a.a.. 


\section{NTN-F 010115}

As NTN-F, títulos também prefixados, se diferem das LTN pelo pagamento semestral de cupom de juros. Em função disso, a trajetória de preços das NTN-F apresenta quedas acentuadas no momento do pagamento dos cupons de juros. A NTN-F 010115, que apresentou RMSE de 3,61\%, é especialmente interessante para observar como a distância entre os preços calculados pelas diferentes metodologias se reduz à medida que se aproxima a data de vencimento do título, como pode ser visto no Gráfico 11.

Gráfico 11 - Preços de mercado e na curva da NTN-F 010115.

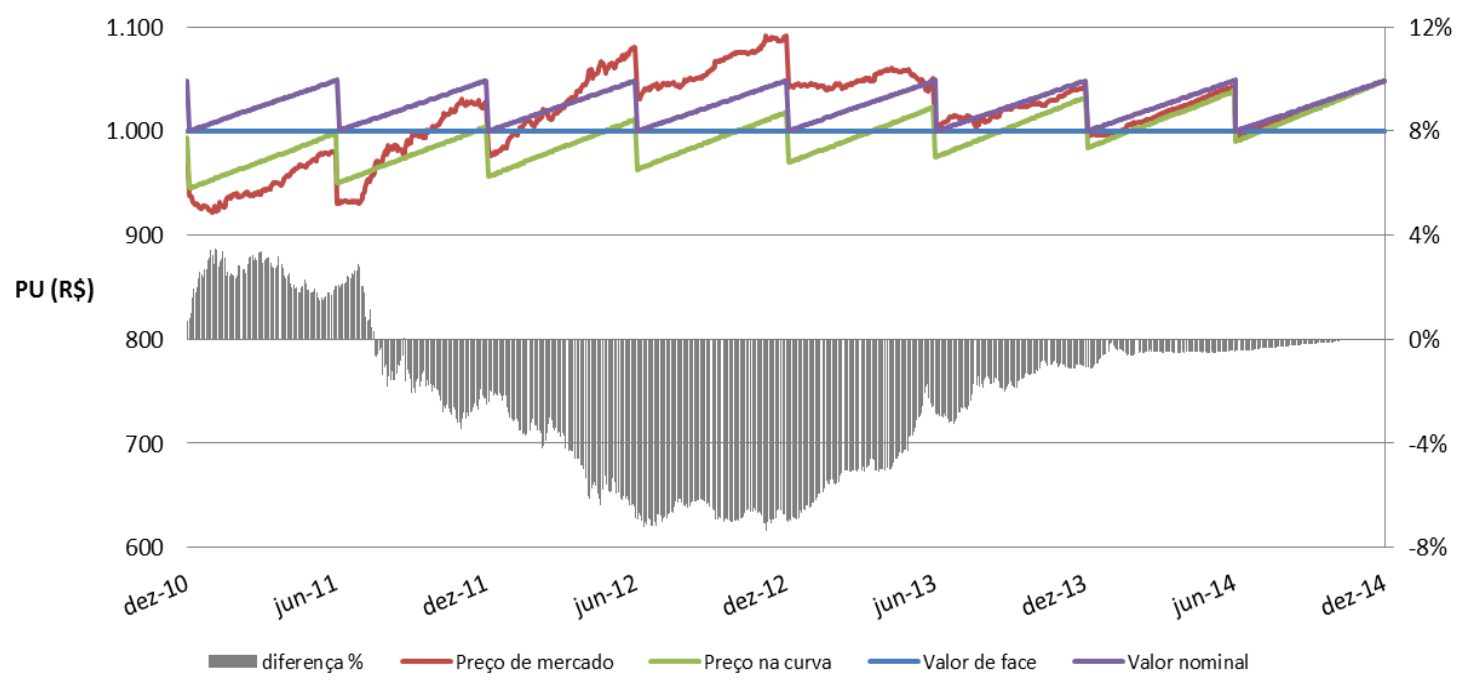

Fonte: Autor, 2016.

RMSE $=\mathbf{3 , 6 1 \%}$ 
Gráfico 12 - Taxas de mercado da NTN-F 010115.

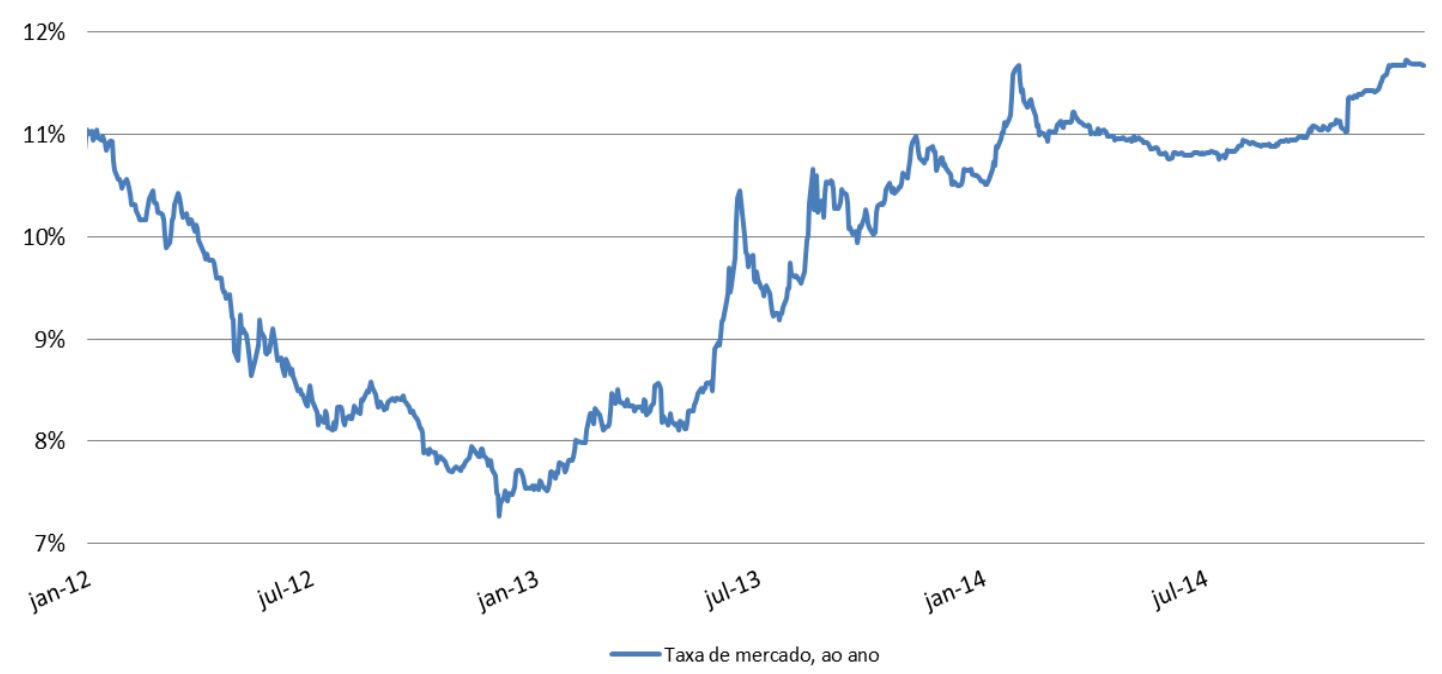

Fonte: Anbima.

\section{NTN-F 010118}

O Gráfico 13 mostra a evolução dos preços da NTN-F 010118 desde sua primeira emissão, ocorrida em janeiro de 2012. A redução das taxas de mercado após a sua primeira emissão levaram os preços de mercado a níveis superiores aos do preço na curva, o que se inverteu com o movimento contrário das taxas observado a partir de 2013, comportamento similar àquele observado na LTN 010116, que teve sua primeira emissão na mesma data.

Pode-se observar, mais uma vez, que os preços na curva são afetados na margem pelas taxas de mercado quando ocorrem novas emissões. Esse efeito pode ser percebido tanto nos momentos em que a taxa de mercado está abaixo da taxa média das emissões, deslocando os preços na curva para cima, quanto na situação inversa, em que as novas emissões são realizadas a taxas acima da taxa média das emissões, reduzindo os preços na curva, como pode ser visto na representação gráfica das séries de preços do título NTN-B 010119 (Gráfico 14). 
Gráfico 13 - Preços de mercado e na curva da NTN-F 010118.

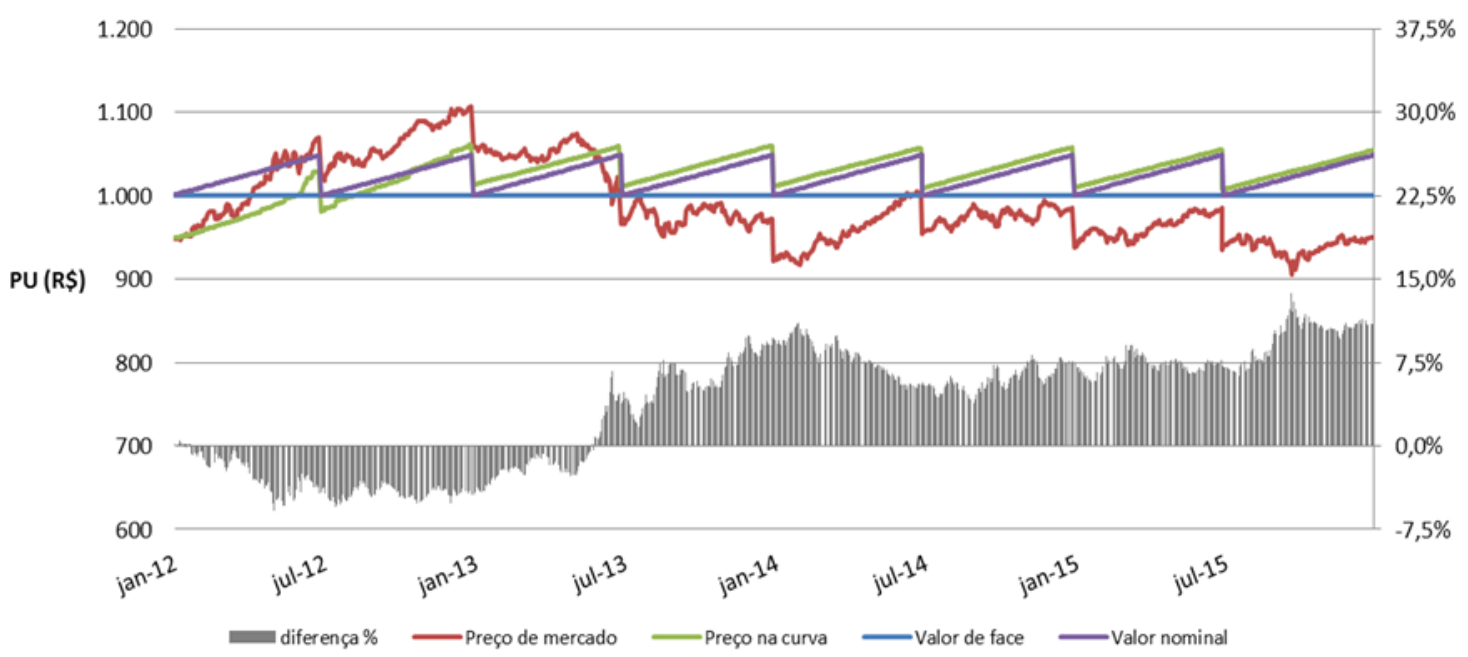

Fonte: Autor, 2016.

$\mathrm{RMSE}=\mathbf{6 , 4 2 \%}$

Gráfico 14 - Preços de mercado e na curva da NTN-F 010119.

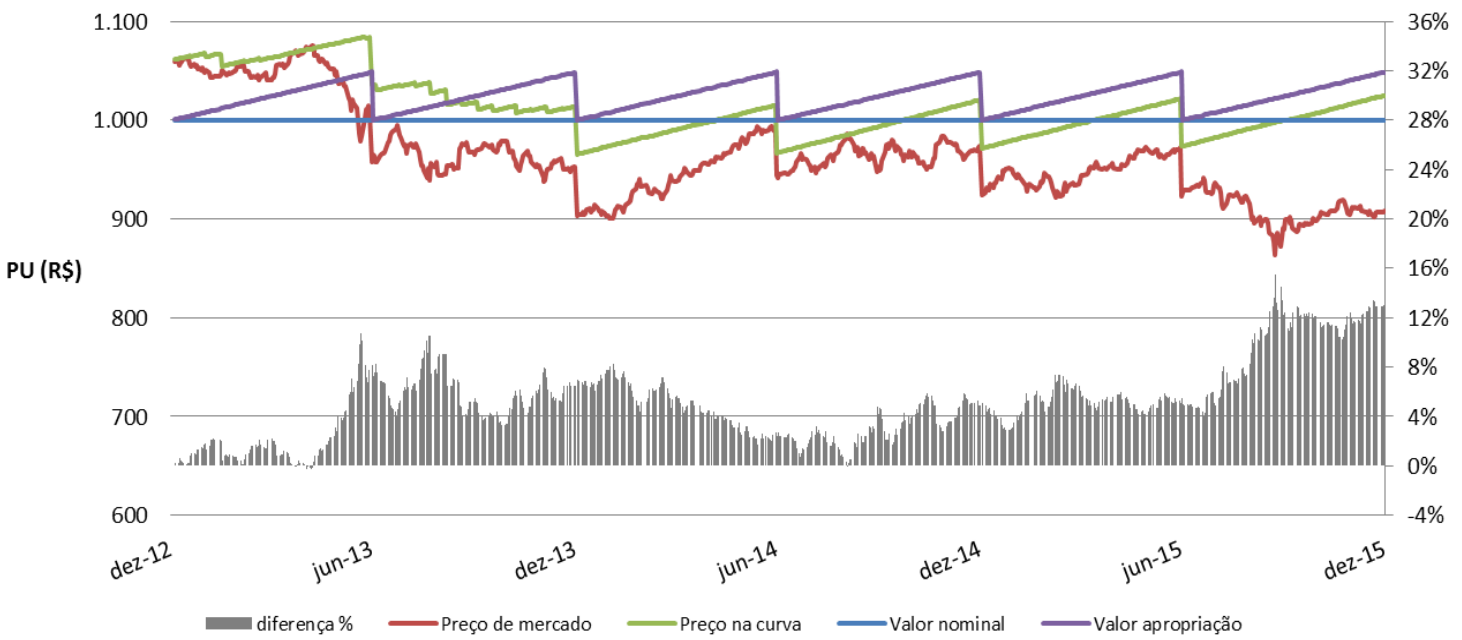

Fonte: Autor, 2016.

$$
\mathrm{RMSE}=\mathbf{6 , 1 0 \%}
$$


Gráfico 15 - Taxas de mercado da NTN-F 010118.

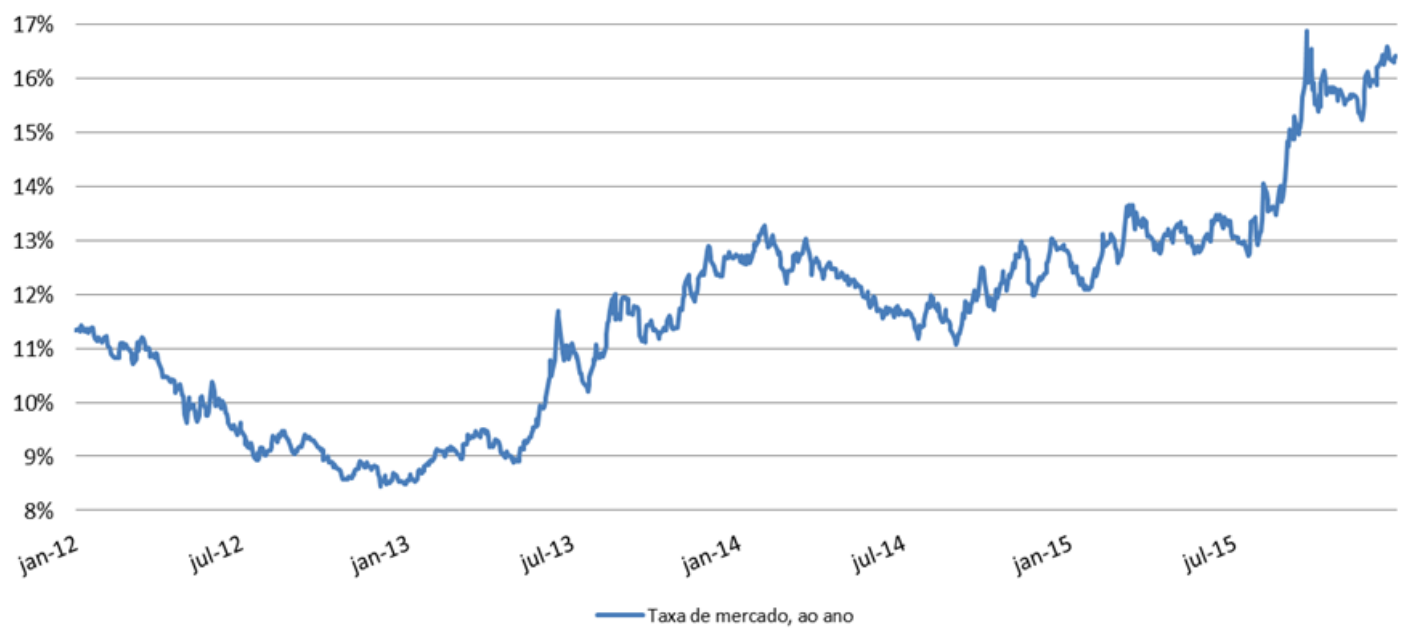

Fonte: Anbima.

\section{NTN-B}

O preço das NTN-B pode ser calculado pela fórmula abaixo.

$$
P U=\operatorname{cotaçã̃o~} x V N A=\left[\left[\frac{(1+\text { cupom })^{0,5}-1}{(1+i)^{\frac{d u 1}{252}}}\right]+\left[\frac{(1+\text { cupom })^{0,5}-1}{(1+i)^{\frac{d u 2}{252}}}\right]+\ldots+\left[\frac{(1+\text { cupom })^{0,5}}{(1+i)^{\frac{d u m}{252}}}\right]\right] \times V N A
$$

Onde:

$d u$ : representa o número de dias úteis entre a data de apuração do preço (inclusive) e a data de vencimento do fluxo do título (exclusive).

$i$ : na precificação pela curva, trata-se da taxa interna de retorno média das emissões, o que é matematicamente equivalente a precificar cada emissão pela sua própria TIR até o vencimento do título; na precificação a valor de mercado, trata-se da taxa pelo qual o título está sendo negociado na data da precificação.

cupom: taxa que determina os fluxos periódicos de pagamento de juros (\% a.a.). Nas NTN-B, essa taxa é de $6 \%$ a.a..

VNA: R\$ 1.000 na data-base (15/07/2000), atualizado pelo IPCA até a data da precificação. 


\section{NTN-B 150840}

A série de preços na curva da NTN-B 150840 apresentou RMSE em relação aos valores de mercado de $13,96 \%$, o que pode ser considerado um dos mais significativos dentre os títulos da DPMFi. Dois fatores podem ser apontados como justificativa para este resultado. Em primeiro lugar, as flutuações das taxas de mercado, que se distanciam da taxa média das emissões, geram as diferenças nos preços apurados por essas duas metodologias. Em segundo, o prazo de vencimento mais alongado desse título torna seus preços mais sensíveis a tais flutuações.

O Gráfico 16, que mostra a trajetória dos preços pelas diferentes metodologias, pode ser dividido em três fases. A primeira, até agosto de 2011, é marcada pela proximidade dos valores apurados pela curva e pelo preço de mercado, o que é justificado pela reduzida volatilidade das taxas de mercado neste período. A segunda fase, até o primeiro semestre de 2013, é caracterizada por redução nas taxas de rentabilidade, elevando os preços de mercado. Nesse intervalo é possível observar que as novas emissões realizadas a taxas mais baixas impactam os preços na curva, que também se elevam durante esta fase em relação à trajetória que seria esperada caso não houvesse novas emissões. No período seguinte, as taxas de mercado se elevaram consideravelmente, passando de $3,7 \%$ a.a. no ponto mais baixo, em janeiro de 2013, a 7,7\% a.a. no pico, em setembro de 2015 (Gráfico 17). Como consequência, houve uma redução acentuada dos preços de mercado, que passaram a níveis abaixo dos preços na curva.

Comparando-se o Gráfico 13, da NTN-F 010118, ao Gráfico 16, da NTN-B 150840, é possível observar o efeito da indexação ao IPCA neste último, fator que diferencia os dois tipos de título. Este efeito é percebido observando-se o comportamento ao longo do tempo dos preços na curva, valores nominais e valores de face dos dois títulos.

Por outro lado, a análise do Gráfico 18 permite verificar a similaridade entre a trajetória dos preços de mercado da NTN-B 150840 e da NTN-B 150545, com esta última registrando o maior RMSE dentre os títulos da Dívida Pública Federal interna, de 17,46\%. 
Gráfico 16 - Preços de mercado e na curva da NTN-B 150840.

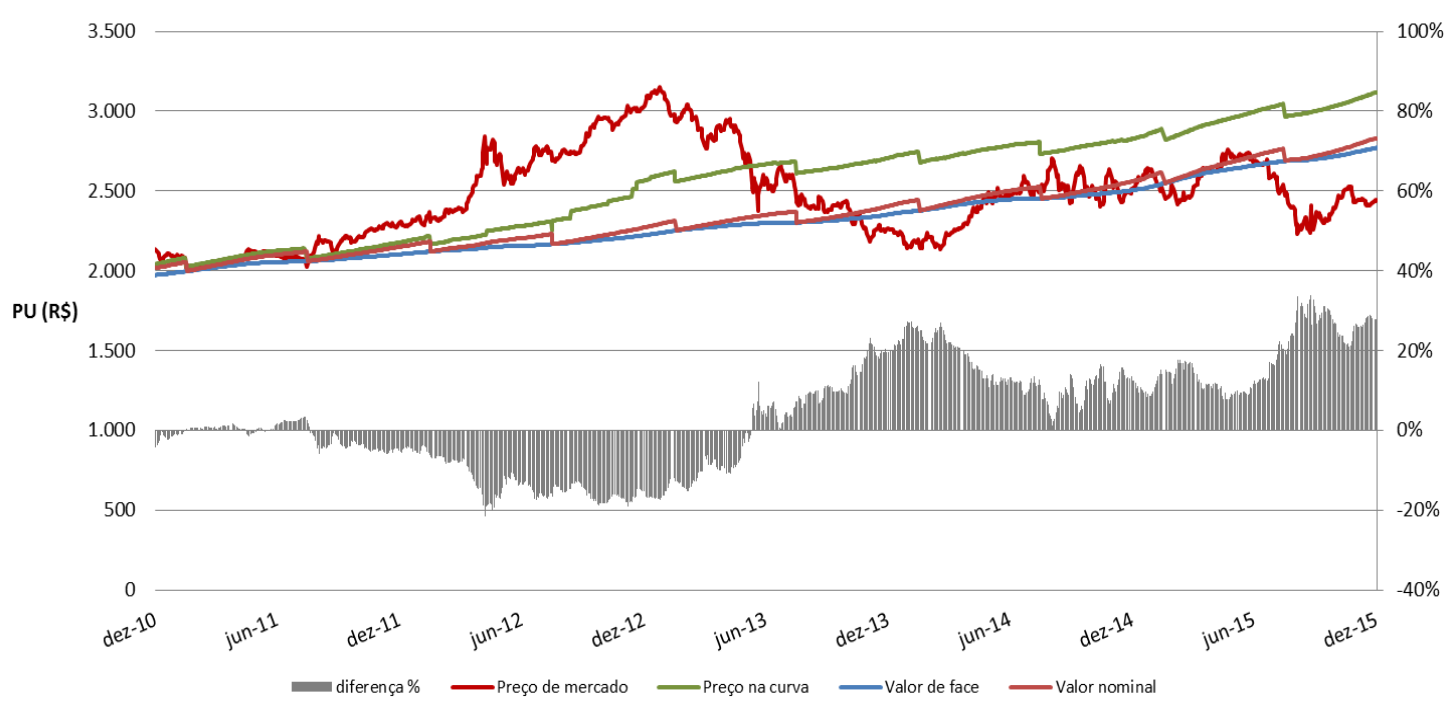

Fonte: Autor, 2016.

\section{RMSE $=13,96 \%$}

\section{Gráfico 17 - Taxas de mercado da NTN-B 150840.}

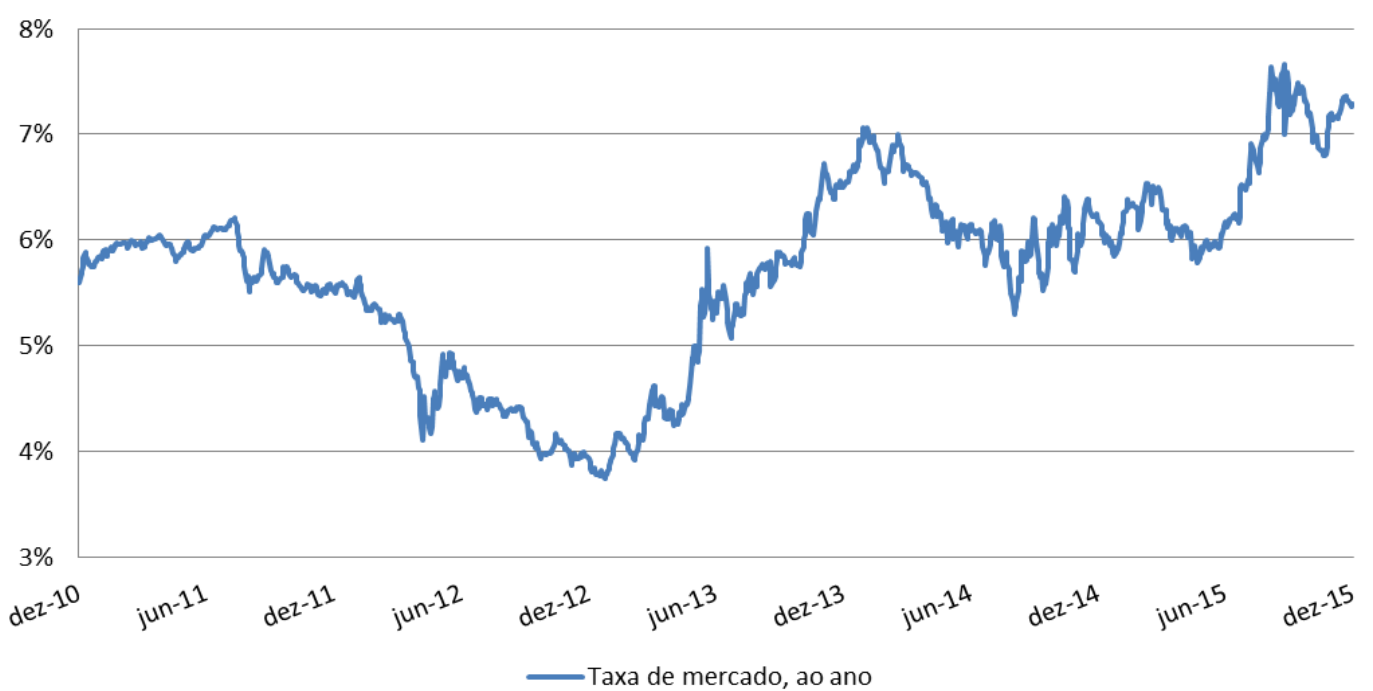

Fonte: Anbima. 
Gráfico 18 - Preços de mercado e na curva da NTN-B 150545.

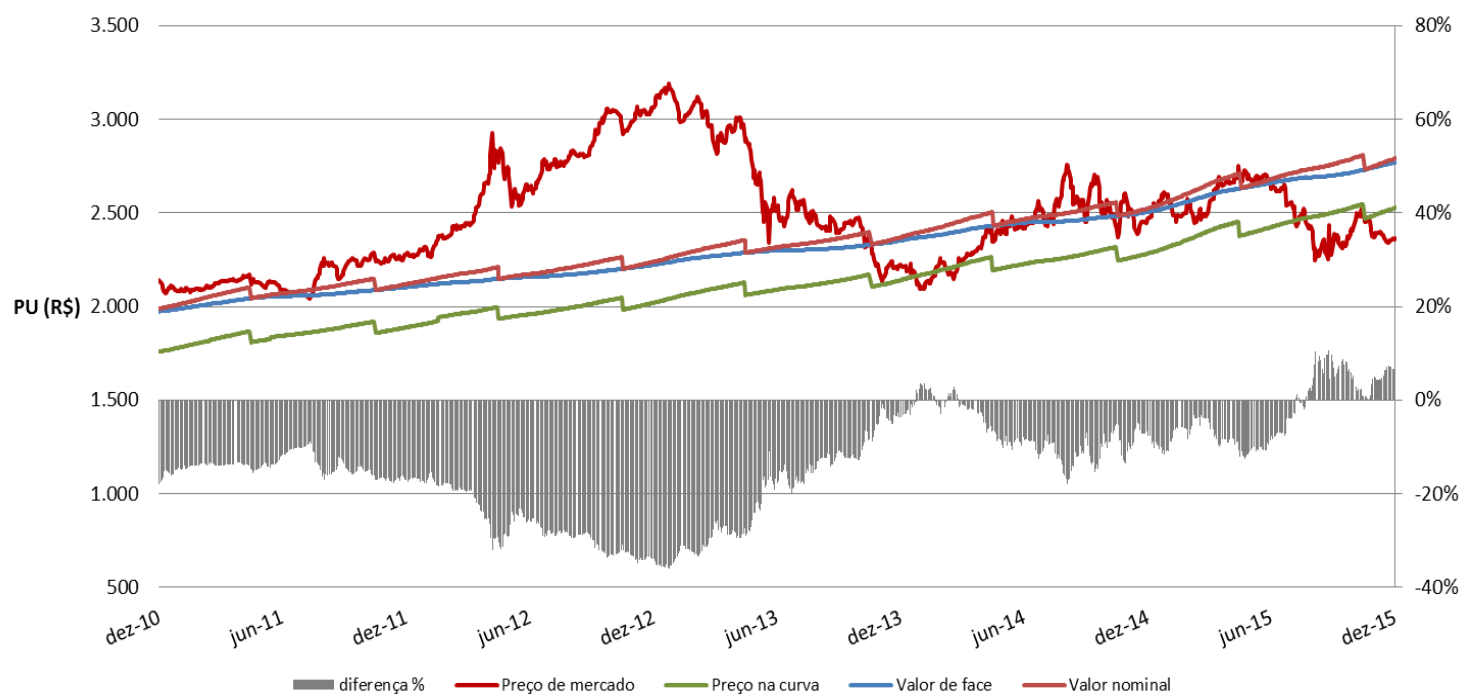

Fonte: Autor, 2016.

\section{RMSE $=\mathbf{1 7 , 4 6 \%}$}

\section{LFT}

A seguir está apresentada a fórmula de cálculo do PU das LFT:

$$
P U=\operatorname{cotaç} \tilde{a} o \times V N A=\frac{1}{(1+i)^{\frac{d u}{252}}} \times V N A
$$

Onde:

$d u$ : representa o número de dias úteis entre a data de apuração do preço (inclusive) e a data de vencimento do fluxo do título (exclusive).

$i$ : na precificação pela curva, trata-se da taxa interna de retorno média das emissões, o que é matematicamente equivalente a precificar cada emissão pela sua própria TIR até o vencimento do título; na precificação a valor de mercado, trata-se da taxa pelo qual o título está sendo negociado na data da precificação.

VNA: R\$ 1.000 na data-base (01/07/2000), atualizado pela taxa Selic diária até a data da precificação. 


\section{LFT 070916}

A série dos preços da LFT 070916 apresentou RMSE de 0,10\%. Graficamente, é possível verificar essa proximidade entre as séries pelas linhas praticamente sobrepostas. Com taxa de rentabilidade muito próxima a zero durante todo o período estudado, a variação dos preços das LFT ocorre apenas pela indexação à taxa Selic, que afeta igualmente o preço desse tipo de título, seja em valores de mercado, na curva ou nominais.

\section{Gráfico 19 - Preços de mercado e na curva da LFT 070916.}

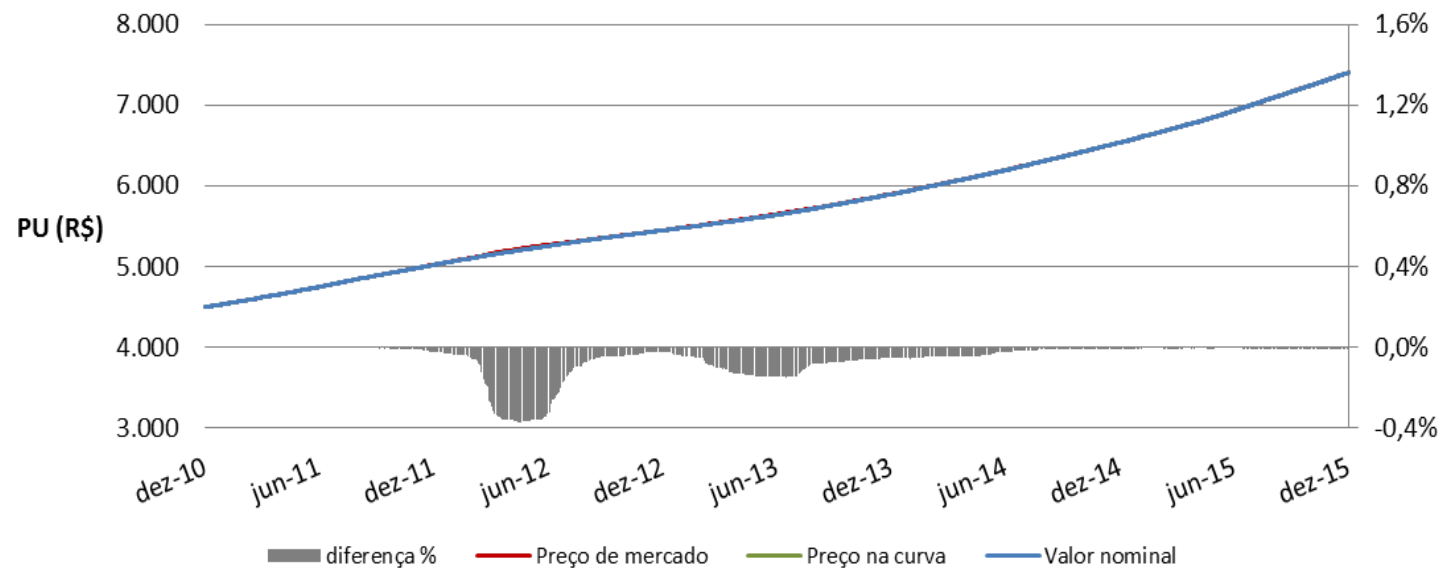

Fonte: Autor, 2016.

\section{RMSE $=\mathbf{0 , 1 0 \%}$}

Gráfico 20 - Taxas de mercado da LFT 070916.

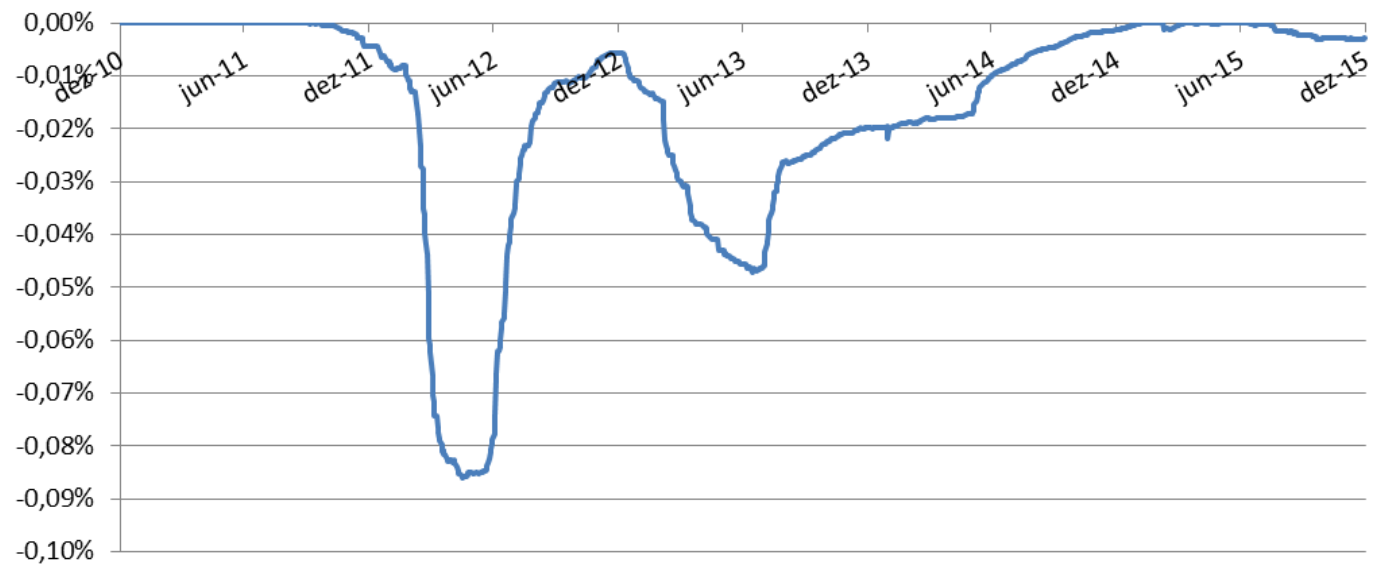

- Taxa de mercado, ao ano

Fonte: Anbima. 


\section{LFT 010318}

A série dos preços da LFT 010318 apresentou RMSE do preço na curva em relação aos preços de mercado de $0,13 \%$. Pode-se verificar que mesmo tendo prazo de vencimento mais alongado, a raiz quadrada do erro quadrático médio permanece bastante reduzida, uma vez que as variações das taxas no período observado foram pouco significativas, flutuando entre $-0,0912 \%$ a.a. a $0,00 \%$ a.a. (Gráfico 22).

Gráfico 21 - Preços de mercado e na curva da LFT 010318.

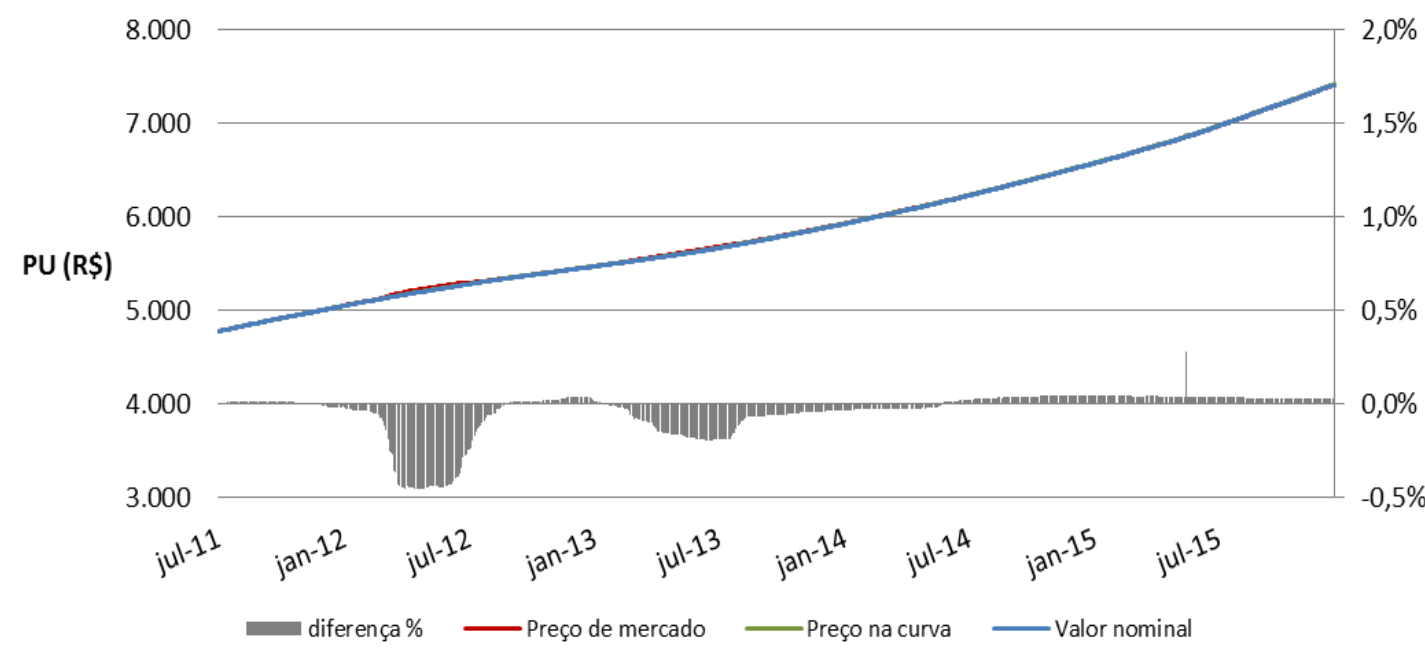

Fonte: Autor, 2016.

$$
\text { RMSE }=0,13 \%
$$

Gráfico 22 - Taxas de mercado da LFT 010318.

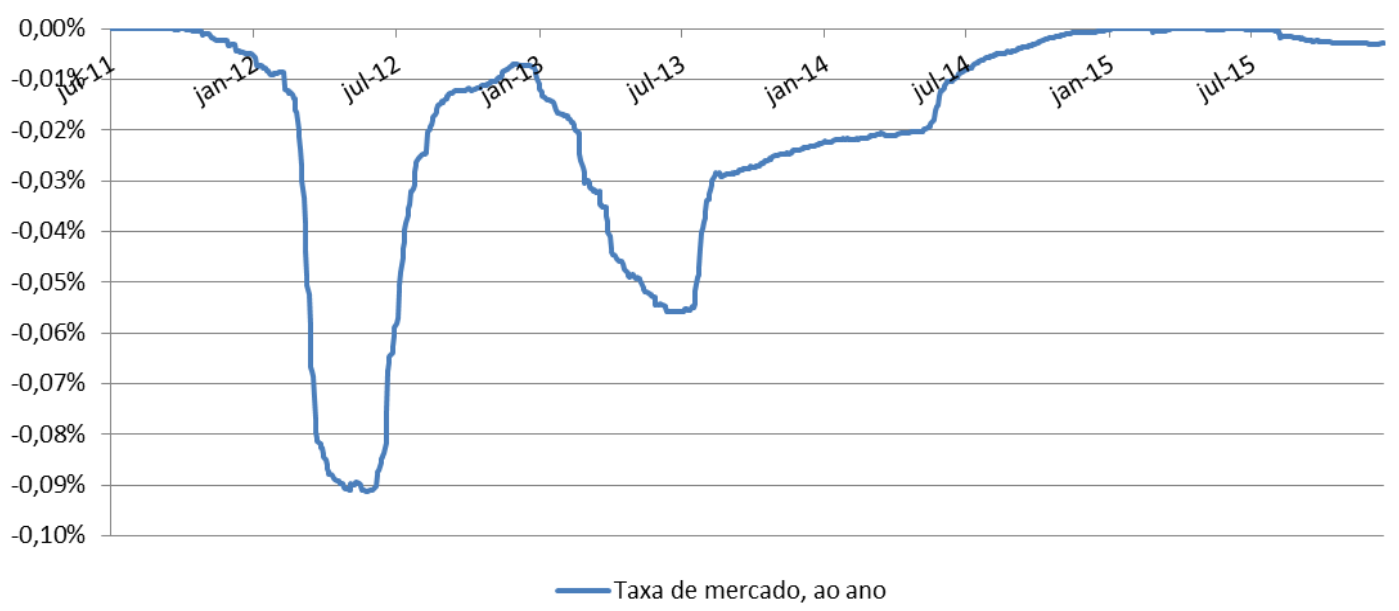

Fonte: Anbima. 
4.2.2 Dívida Pública Mobiliária Federal externa - DPMFe

Tabela 2 - Resultados da DPMFe, por título

\begin{tabular}{|c|c|c|c|c|}
\hline & Título & Data $1^{\text {a }}$ emissão & Taxa $1^{a}$ emissão & RMSE curva \\
\hline \multirow{5}{*}{ Euro } & Euro 2011 & 24/01/2001 & $9,93 \%$ & $0,40 \%$ \\
\hline & Euro 2012 & 24/09/2004 & $8,70 \%$ & $5,70 \%$ \\
\hline & Euro 2015 & 03/02/2005 & $7,55 \%$ & $9,44 \%$ \\
\hline & Eurolira 2017 & 29/06/1997 & $10,84 \%$ & $23,20 \%$ \\
\hline & Euro 2021 & 03/04/2014 & $2,96 \%$ & $4,91 \%$ \\
\hline & Euro & & & $11,59 \%$ \\
\hline \multirow{23}{*}{ Global } & Global 2011 & 07/08/2003 & $11,21 \%$ & $3,40 \%$ \\
\hline & Global 2012 & $11 / 01 / 2002$ & $12,60 \%$ & $6,86 \%$ \\
\hline & Global 2013 & $17 / 06 / 2003$ & $10,58 \%$ & $12,32 \%$ \\
\hline & Global 2014 & $14 / 07 / 2004$ & $10,80 \%$ & $14,34 \%$ \\
\hline & Global 2015 & 07/03/2005 & $7,90 \%$ & $12,34 \%$ \\
\hline & Global 2017 & $14 / 11 / 2006$ & $6,25 \%$ & $11,61 \%$ \\
\hline & Global 2019 & $14 / 10 / 2004$ & $9,15 \%$ & $25,18 \%$ \\
\hline & Global 2019-A & 13/01/2009 & $6,13 \%$ & $12,57 \%$ \\
\hline & Global 2020 & 26/01/2000 & $13,27 \%$ & $36,47 \%$ \\
\hline & Global 2021 & $22 / 04 / 2010$ & $5,00 \%$ & $6,83 \%$ \\
\hline & Global 2023 & $12 / 09 / 2012$ & $2,69 \%$ & $12,01 \%$ \\
\hline & Global 2024 & 22/03/2001 & $12,91 \%$ & $44,77 \%$ \\
\hline & Global 2024-B & 07/08/2003 & $12,59 \%$ & $43,71 \%$ \\
\hline & Global 2025 & 04/02/2005 & $8,90 \%$ & $28,89 \%$ \\
\hline & Global 2025-A & $01 / 11 / 2013$ & $4,31 \%$ & $6,93 \%$ \\
\hline & Global 2027 & 09/06/1997 & $10,90 \%$ & $39,11 \%$ \\
\hline & Global 2030 & 06/03/2000 & $13,15 \%$ & $46,73 \%$ \\
\hline & Global 2034 & 20/01/2004 & $8,75 \%$ & $30,67 \%$ \\
\hline & Global 2037 & 18/01/2006 & $7,56 \%$ & $13,11 \%$ \\
\hline & Global 2040 & $17 / 08 / 2000$ & $13,73 \%$ & $32,58 \%$ \\
\hline & Global 2041 & 07/10/2009 & $5,80 \%$ & $12,27 \%$ \\
\hline & Global 2045 & 01/08/2014 & $5,13 \%$ & $17,70 \%$ \\
\hline & Global A-Bond 2018 & $01 / 08 / 2005$ & $7,58 \%$ & $6,48 \%$ \\
\hline \multirow{5}{*}{ Global BRL } & Global & & & $20,09 \%$ \\
\hline & Global BRL 2016 & 26/09/2005 & $12,75 \%$ & $11,70 \%$ \\
\hline & Global BRL 2022 & 13/09/2006 & $12,88 \%$ & $18,72 \%$ \\
\hline & Global BRL 2024 & $27 / 04 / 2012$ & $8,60 \%$ & $10,58 \%$ \\
\hline & Global BRL 2028 & $14 / 02 / 2007$ & $10,68 \%$ & $10,30 \%$ \\
\hline & Global BRL & & & $10,88 \%$ \\
\hline
\end{tabular}

Fonte: Autor, 2016.

A Tabela 2 mostra os resultados obtidos do RMSE do preço na curva em relação ao valor de mercado de cada um dos títulos da DPMFe. São apresentados, ainda, a data e a taxa de 
rentabilidade da primeira emissão dos títulos, que constituem informações relevantes para a análise de seus resultados.

Como acontece na DPMFi, as diferenças entre os valores de mercado e os valores na curva e nominais apurados no estudo empírico ocorrem em função das flutuações das taxas de rentabilidade dos títulos públicos da DPMFe, uma vez que as taxas de mercado são usadas como taxa de desconto na marcação a mercado, enquanto os preços na curva são calculados descontando-se os fluxos do título pela taxa média das emissões.

Os preços dos títulos são afetados de maneiras diferentes, sendo os títulos com maior prazo de vencimento mais sensíveis às alterações das taxas. Isso pode ser observado empiricamente pelo RMSE do preço na curva em relação aos valores de mercado dos bônus Global, de 20,09\%, superior aos das demais siglas da DPMFe.

Uma característica comum aos títulos da DPMFe é o pagamento de cupom de juros: semestrais, nos bônus Global e Global BRL; e anuais, no caso dos bônus Euro. O efeito do pagamento de cupom no preço dos títulos é a redução abrupta do seu valor na data do referido pagamento, o que pode ser percebido tanto no valor de mercado, quanto no preço na curva e no valor nominal dos títulos. O pagamento do principal ocorre integralmente no vencimento dos títulos, exceção feita ao Global A-Bond 2018, que amortiza o principal em 18 parcelas semestrais.

A seguir, as trajetórias dos preços apurados pelas diferentes metodologias de alguns dos títulos da DPMFe são analisadas de forma individual.

\section{Euro}

Abaixo está apresentada a fórmula de precificação dos bônus Euro.

$$
P U^{12}=\left[\left[\frac{(\text { cupom })}{(1+i)^{f a 1}}\right]+\left[\frac{(\text { cupom })}{(1+i)^{f a 2}}\right]+\ldots+\left[\frac{(\text { cupom })+1}{(1+i)^{f a n}}\right]\right] \times 1.000(\text { EUR) }
$$

Onde:

fa: representa a fração-ano entre a data de apuração do preço e a data de vencimento do fluxo do título, apurada pelo padrão de contagem dias corridos/dias corridos;

\footnotetext{
12 Trata-se do preço sujo, que é o preço pelo qual o título é efetivamente transacionado no mercado internacional.
} 
$i$ : na precificação pela curva, trata-se da taxa interna de retorno média das emissões, o que é matematicamente equivalente a precificar cada emissão pela sua própria TIR efetiva até o vencimento do título; na precificação a valor de mercado, trata-se da taxa efetiva pela qual o título está sendo negociado na data da precificação.

cupom: taxa nominal ao ano que determina o pagamento anual de juros. A taxa varia de acordo com o título.

\section{Euro 2021}

O Euro 2021 teve sua primeira e única emissão em abril de 2014, com yield de 2,961\% a.a.. Mesmo apresentando flutuações, o seu preço de mercado não apresenta distanciamento acentuado em relação ao preço na curva no início da trajetória. Essa diferença aumentou a partir de agosto de 2015, quando as taxas de juros desse bônus apresentaram elevação acentuada, variando entre $2,2 \%$ a.a. e 6,2\% a.a. no período estudado, como pode ser visto nos Gráficos 23 e 24.

Gráfico 23 - Preços de mercado e na curva do Euro 2021.

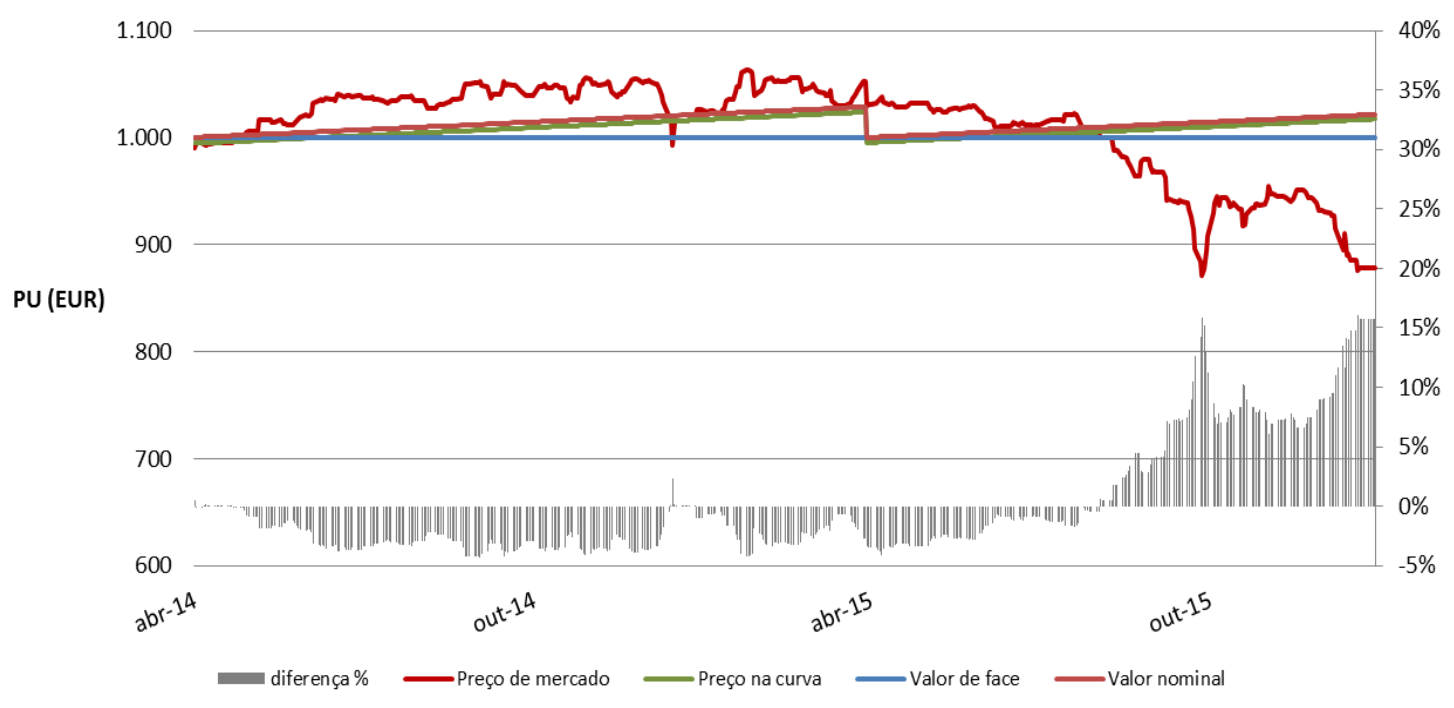

Fonte: Autor, 2016.

$$
\text { RMSE }=4,91 \%
$$


Gráfico 24 - Taxas de mercado do Euro 2021.

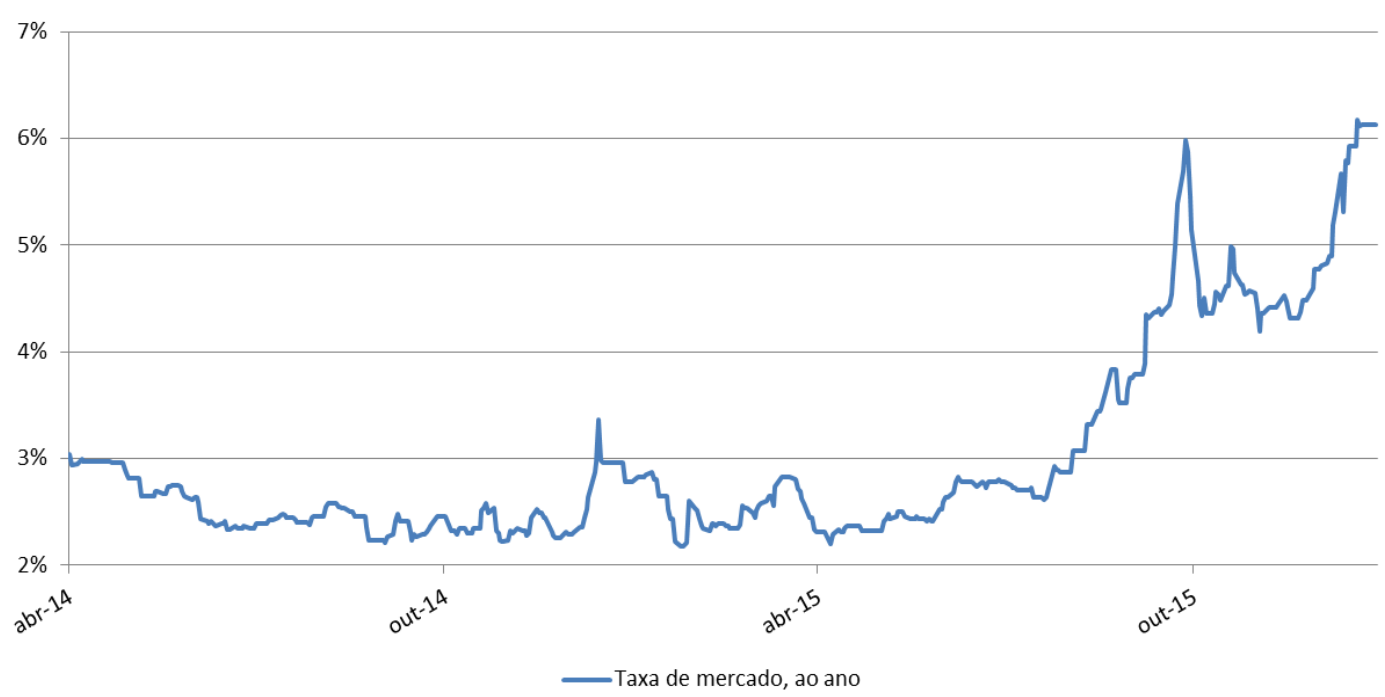

Fonte: Bloomberg.

\section{Global}

A seguir está apresentada a fórmula de precificação do bônus Global.

$$
P U^{13}=\left[\left[\frac{(\text { cupom } / 2)}{(1+i)^{f a 1}}\right]+\left[\frac{(\text { cupom } / 2)}{(1+i)^{f a 2}}\right]+\ldots+\left[\frac{(\text { cupom } / 2)+1}{(1+i)^{f a n}}\right]\right] \times 1.000(\text { USD })
$$

Onde:

$f a$ : representa a fração-ano entre a data de apuração do preço e a data de vencimento do fluxo do título apurado pelo padrão de contagem de dias 30/360, que considera o ano com 12 meses de 30 dias.

$i$ : na precificação pela curva, trata-se da taxa interna de retorno média das emissões, o que é matematicamente equivalente a precificar cada emissão pela sua própria TIR efetiva até o vencimento do título; na precificação a valor de mercado, trata-se da taxa efetiva pela qual o título está sendo negociado na data da precificação.

cupom: taxa nominal ao ano que determina o pagamento semestral de juros. A taxa varia de acordo com o título.

\footnotetext{
${ }^{13}$ Trata-se do preço sujo, que é o preço pelo qual o título é efetivamente transacionado no mercado internacional.
} 


\section{Gráfico 25 - Taxas de mercado dos bônus Global}

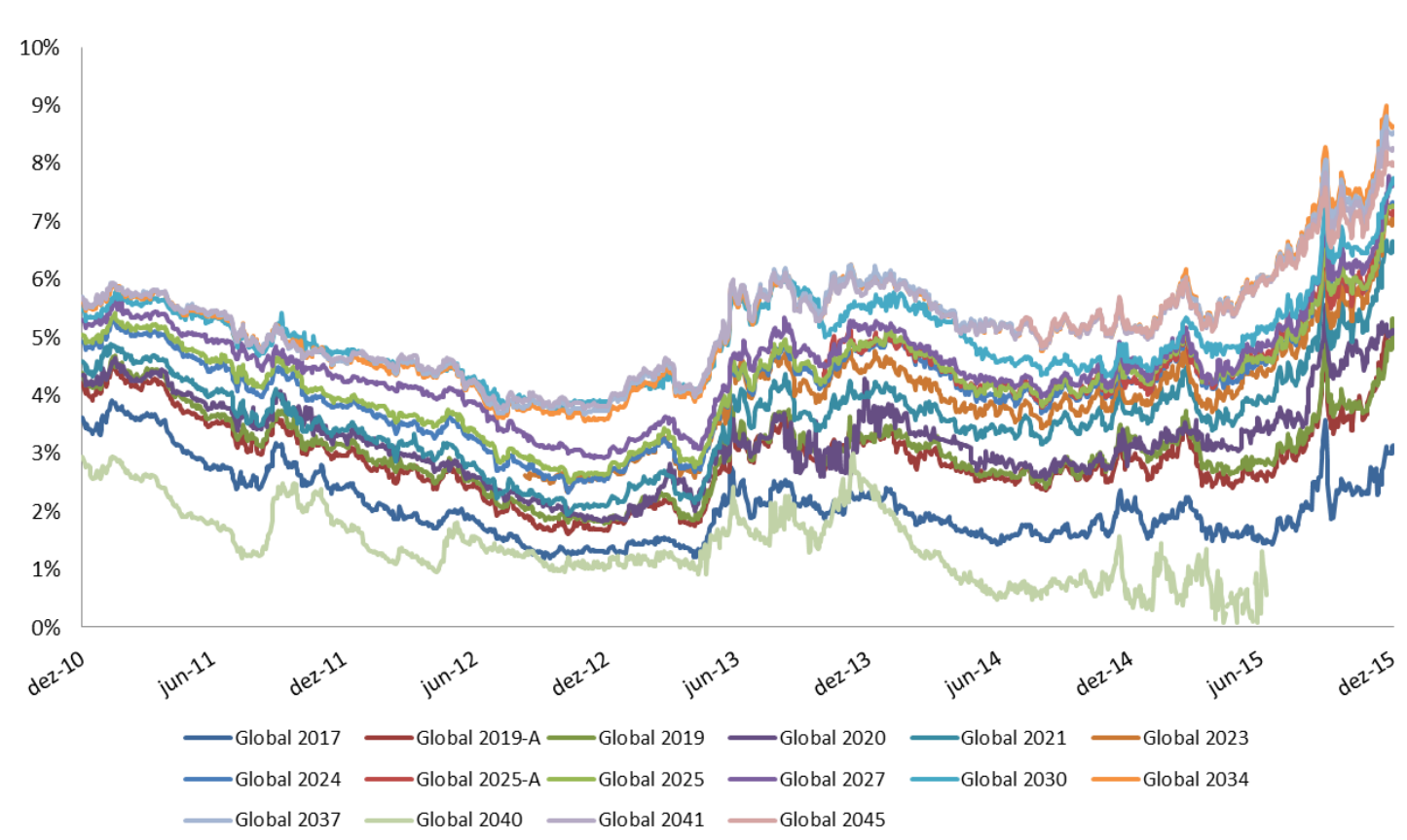

Fonte: Bloomberg.

O Gráfico 25 mostra a evolução das taxas dos bônus Global no período de dezembro de 2010 a dezembro de 2015. Pode-se observar a flutuação das taxas nesse período e a estrutura temporal das taxas de juros, que mostra a redução na percepção de risco pelo credor em função da redução do prazo de maturidade dos títulos. Tais flutuações conferem aos preços de mercado uma trajetória irregular, enquanto a linha formada pela série de preços na curva tem uma trajetória mais previsível, como será visto nos exemplos a seguir.

O Global 2040 pode ser considerado um ponto fora da curva por possuir, na sua emissão, uma cláusula de opção de recompra em agosto de 2015 por seu preço ao par (100\% do valor de face - US\$ 1.000), que foi exercida em sua totalidade pelo Tesouro Nacional. Por essa peculiaridade, o Global 2040 já vinha sendo precificado como um bônus com vencimento em 2015, como pode ser observado pelo comportamento de suas taxas.

A partir desse ponto, analisa-se individualmente alguns dos bônus Global, o que permite explorar aspectos do comportamento das séries de preços apurados pelas diferentes metodologias.

\section{Global 2019/Global 2019 N}

As séries de preços dos bônus Global 2019 e Global 2019 N estão apresentadas nos gráficos 26 e 27, respectivamente. Apesar de terem seus vencimentos no mesmo ano, esses dois 
bônus apresentaram resultados de RMSE do preço na curva em relação ao valor de mercado bastante distintos. Enquanto o Global 2019 apresentou RMSE de 25,18\%, o Global $2019 \mathrm{~N}$ teve RMSE significativamente menor, de $12,57 \%$. Graficamente, é possível perceber o maior distanciamento dos preços de mercado em relação aos valores na curva no Global 2019. Esses resultados se devem às diferentes taxas de retorno dos títulos nas suas emissões. O Global 2019 teve sua primeira emissão em outubro de 2004, com yield de 9,15\% a.a. O Global 2019 N, por sua vez, teve sua primeira emissão em janeiro de 2009, com yield de 6,13\% a.a., mais próxima das taxas de mercado registradas no período analisado.

Outro aspecto relevante a ser destacado nos gráficos é a redução gradual da diferença entre o preço na curva e o valor nominal dos títulos. Essa distância, que vai se reduzindo ao longo do tempo em função da aproximação da data de vencimento, tem origem no ágio ou deságio no momento da emissão, ou, em outras palavras, na diferença entre o cupom de juros e a taxa de retorno efetiva do bônus.

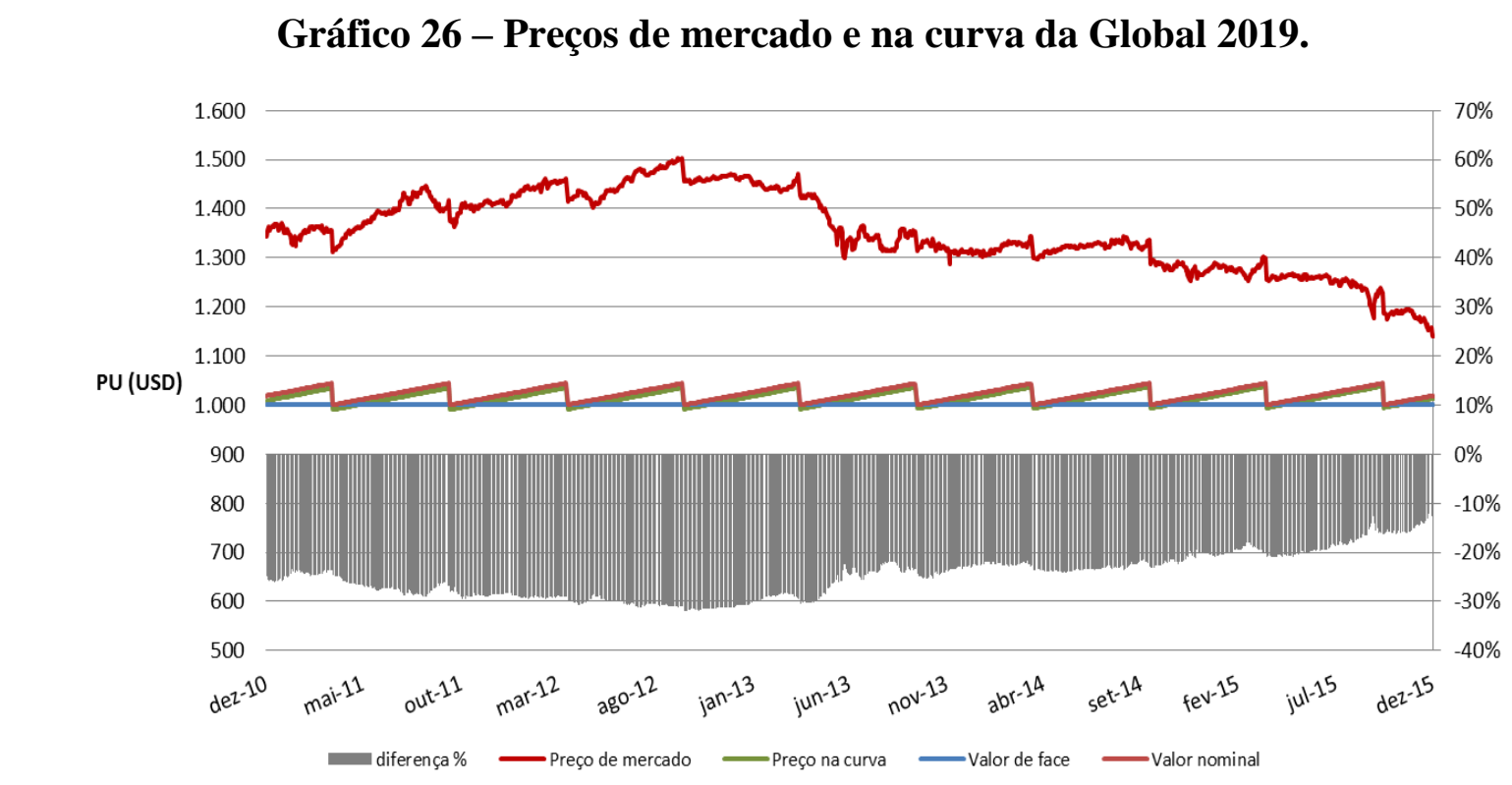

Fonte: Autor, 2016.

RMSE $=25,18 \%$ 
Gráfico 27 - Preços de mercado e na curva da Global 2019 N.

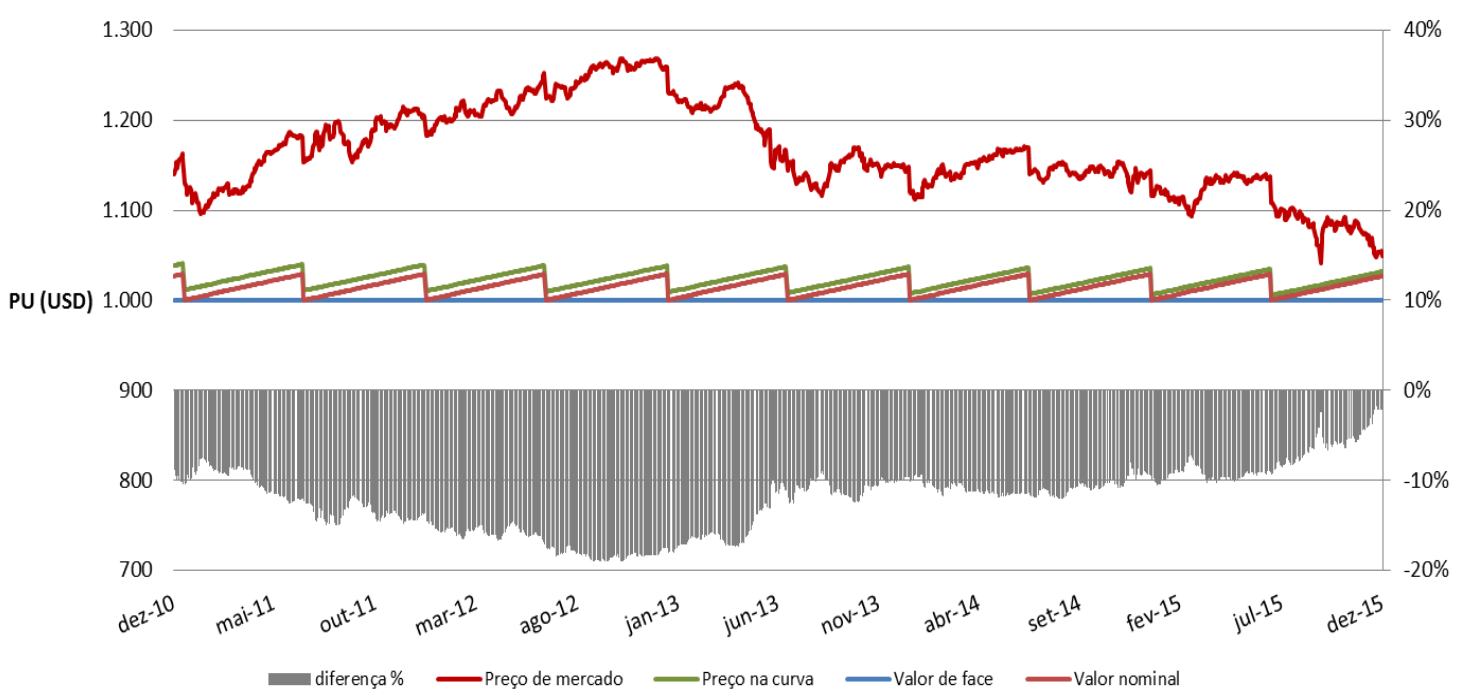

Fonte: Autor, 2016.

\section{RMSE $=12,57 \%$}

\section{Global 2021}

O gráfico das séries de preços do Global 2021 expõe o impacto das novas emissões na trajetória dos valores apurados pela curva. Durante o período estudado, o bônus Global 2021 teve duas novas emissões, em julho de 2011 e janeiro de 2012, com yield inferiores à taxa média das emissões anteriores (4,188\% a.a. e 3,449\% a.a., respectivamente). Como consequência, tem-se um deslocamento do preço na curva para cima, o que aproxima esses valores da série de preços de mercado. Isso explica o RMSE de 6,83\%, significativamente inferior aos dos demais títulos com prazos de vencimento equivalentes. 
Gráfico 28 - Preços de mercado e na curva da Global 2021.

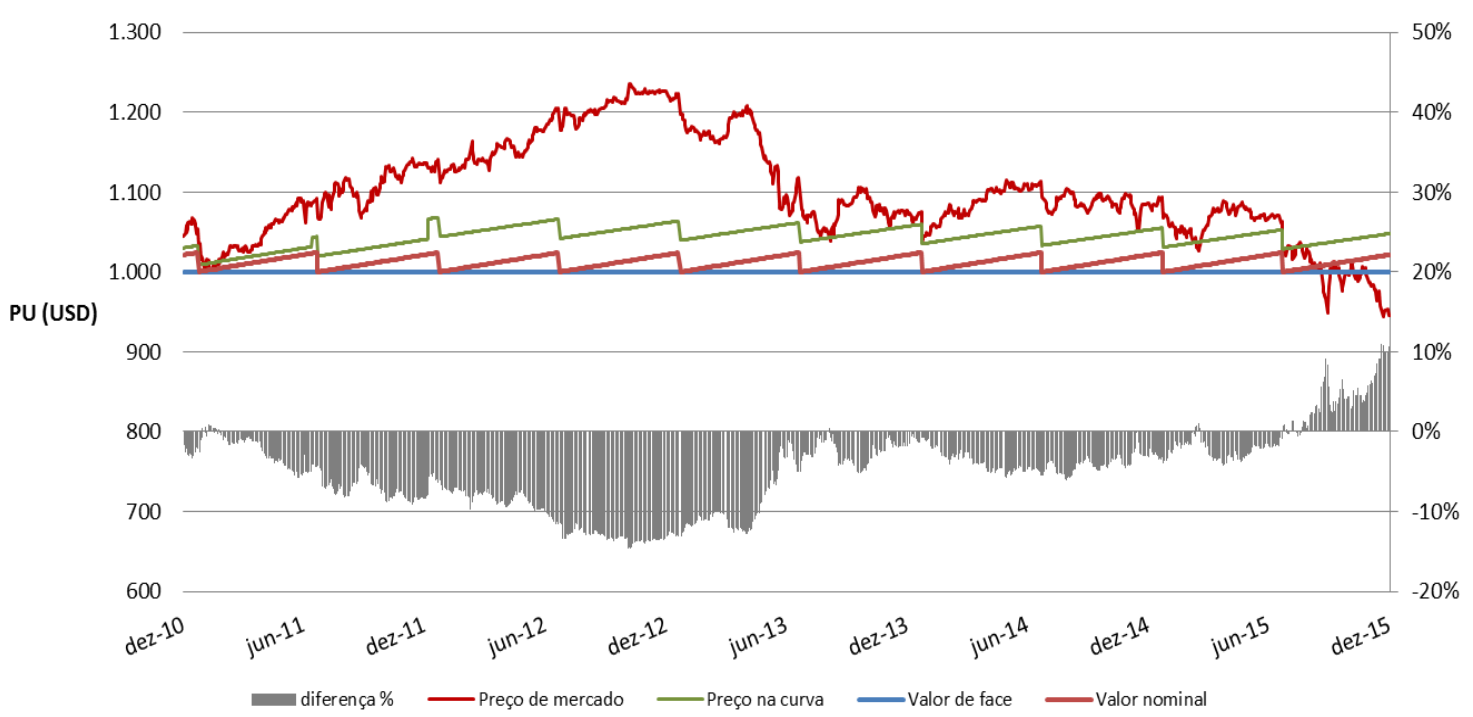

Fonte: Autor, 2016.

$$
\mathrm{RMSE}=\mathbf{6 , 8 3 \%}
$$

\section{Global 2030}

O bônus Global 2030 registrou o maior resultado de RMSE entre os títulos da DPF incluídos no estudo, de 46,73\%, o que é justificado, sobretudo, pela diferença entre as suas taxas de emissão (13,2\% a.a. e 14,5\% a.a.) e as taxas de mercado durante o período analisado, que variaram entre $3,7 \%$ a.a. e $7,7 \%$ a.a. (Gráfico 25 ). 
Gráfico 29 - Preços de mercado e na curva da Global 2030.

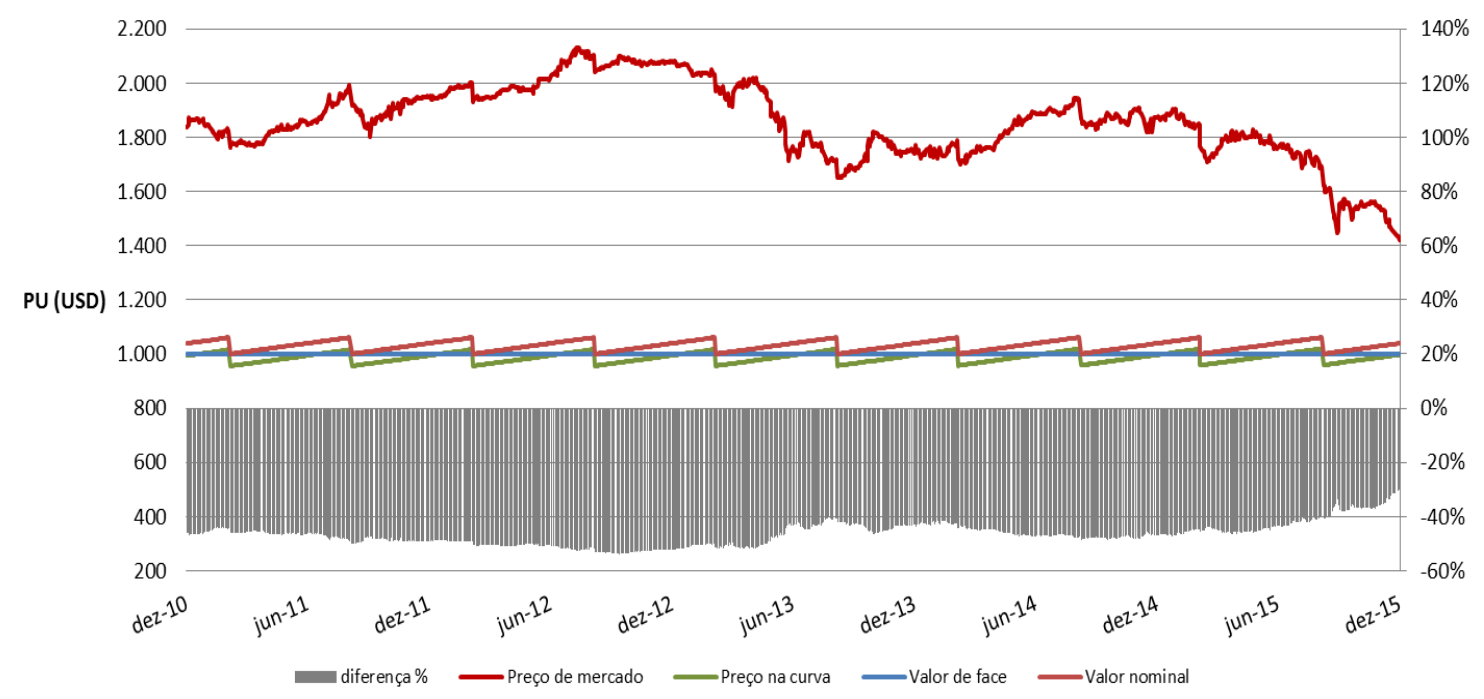

Fonte: Autor, 2016.

\section{RMSE $=46,73 \%$}

\section{Global 2041}

O gráfico da série de preços do Global 2041 mostra, de maneira similar àquela observada no comportamento dos preços do bônus Global 2021, a forma como uma nova emissão afeta a trajetória dos preços na curva.

A nova emissão do bônus Global 2041, realizada em novembro de 2011, teve yield de 4,694\% a.a., inferior à taxa média das emissões anteriores, provocando um ajuste do preço na curva, que se aproxima da série de preços de mercado. Este fato também explica o RMSE de $12,27 \%$, inferior aos dos demais bônus Global com prazos médios equivalentes. 


\section{Gráfico 30 - Preços de mercado e na curva da Global 2041.}

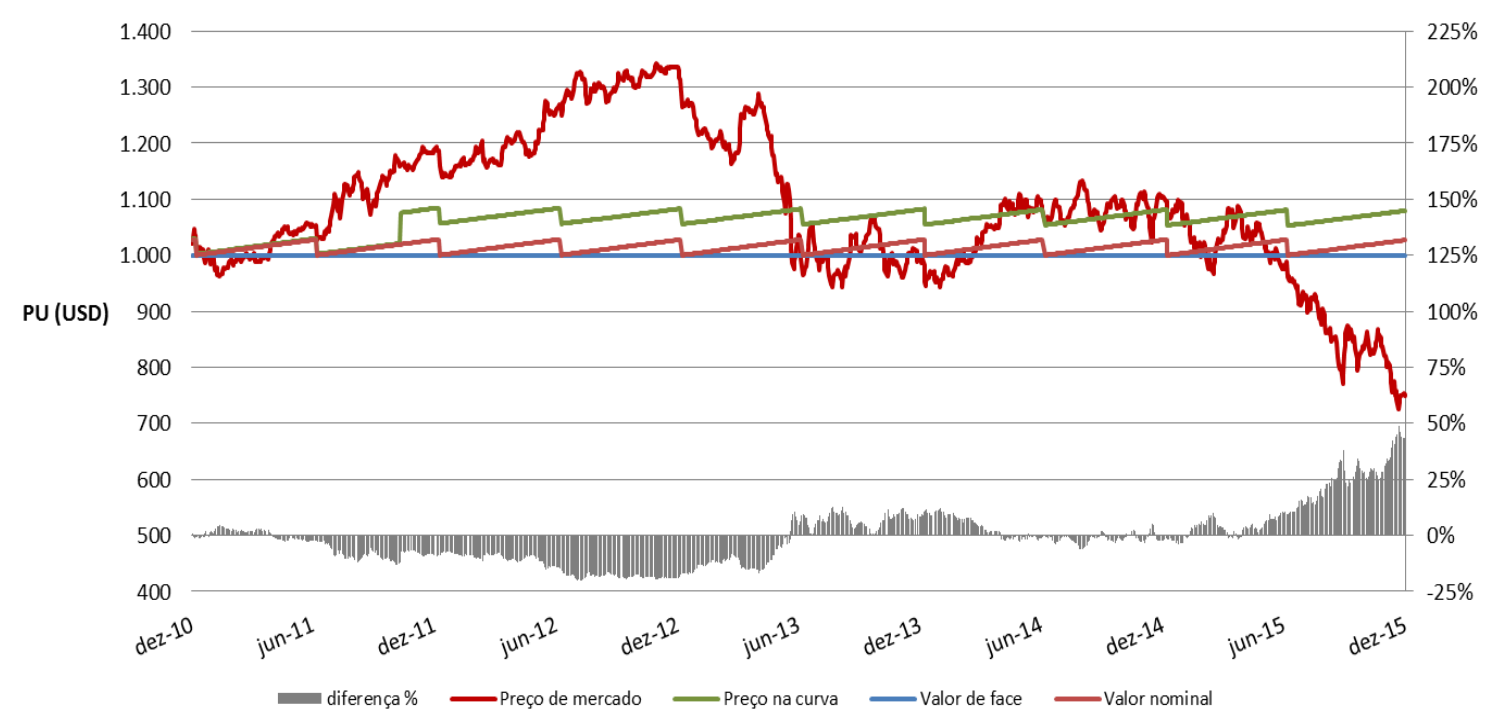

Fonte: Autor, 2016.

\section{RMSE $=12,27 \%$}

\section{Global BRL}

A precificação dos bônus Global BRL é feita pela seguinte fórmula:

$$
P U^{14}=\left[\left[\frac{(\text { cupom } / 2)}{(1+i)^{f a 1}}\right]+\left[\frac{(\text { cupom } / 2)}{(1+i)^{f a 2}}\right]+\ldots+\left[\frac{(\text { cupom } / 2)+1}{(1+i)^{f a n}}\right]\right] \times 1.000(\text { BRL })
$$

Onde:

fa: representa a fração-ano entre a data de apuração do preço e a data de vencimento do fluxo do título apurado pelo padrão de contagem de dias 30/360, que considera o ano com 12 meses de 30 dias.

$i$ : na precificação pela curva, trata-se da taxa interna de retorno média das emissões, o que é matematicamente equivalente a precificar cada emissão pela sua própria TIR efetiva até o vencimento do título; na precificação a valor de mercado, trata-se da taxa efetiva pela qual o título está sendo negociado na data da precificação.

cupom: taxa nominal ao ano que determina o pagamento semestral de juros. A taxa varia de acordo com o título.

\footnotetext{
${ }^{14}$ Trata-se do preço sujo, que é o preço pelo qual o título é efetivamente transacionado no mercado internacional.
} 


\section{Global BRL 2028}

A série de preços de mercado, preços na curva e valores nominal do bônus Global BRL 2028 mostram comportamento similar ao observado nos bônus Global, porém com preços em reais.

Durante o período estudado, não houve novas emissões no mercado primário do Global BRL 2028, o que justifica a trajetória regular dos preços na curva, apresentando quedas nos pagamentos semestrais de cupom de juros. Por outro lado, as oscilações da linha que marca os preços de mercado refletem a volatilidade das taxas do Global BRL 2028 no mercado secundário, que atingiram o menor valor (6,7\% a.a.) em janeiro de 2013 e o maior (13,8\% a.a.) em outubro de 2015 (Gráfico 32). O reflexo dessas oscilações é o RMSE do preço na curva em relação ao valor de mercado, de 10,30\%.

Gráfico 31 - Preços de mercado e na curva da Global BRL 2028.

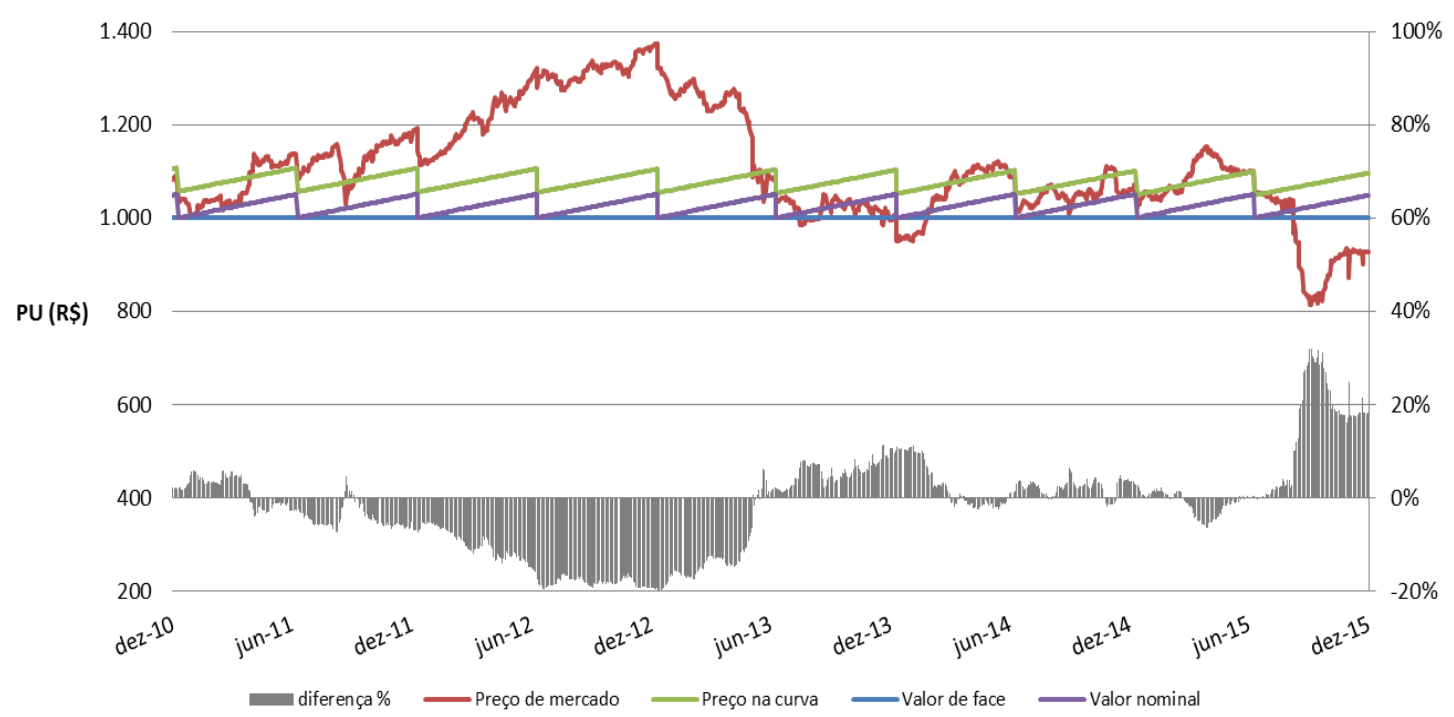

Fonte: Autor, 2016.

$$
\text { RMSE }=10,30 \%
$$


Gráfico 32 - Taxas de mercado do Global BRL 2028

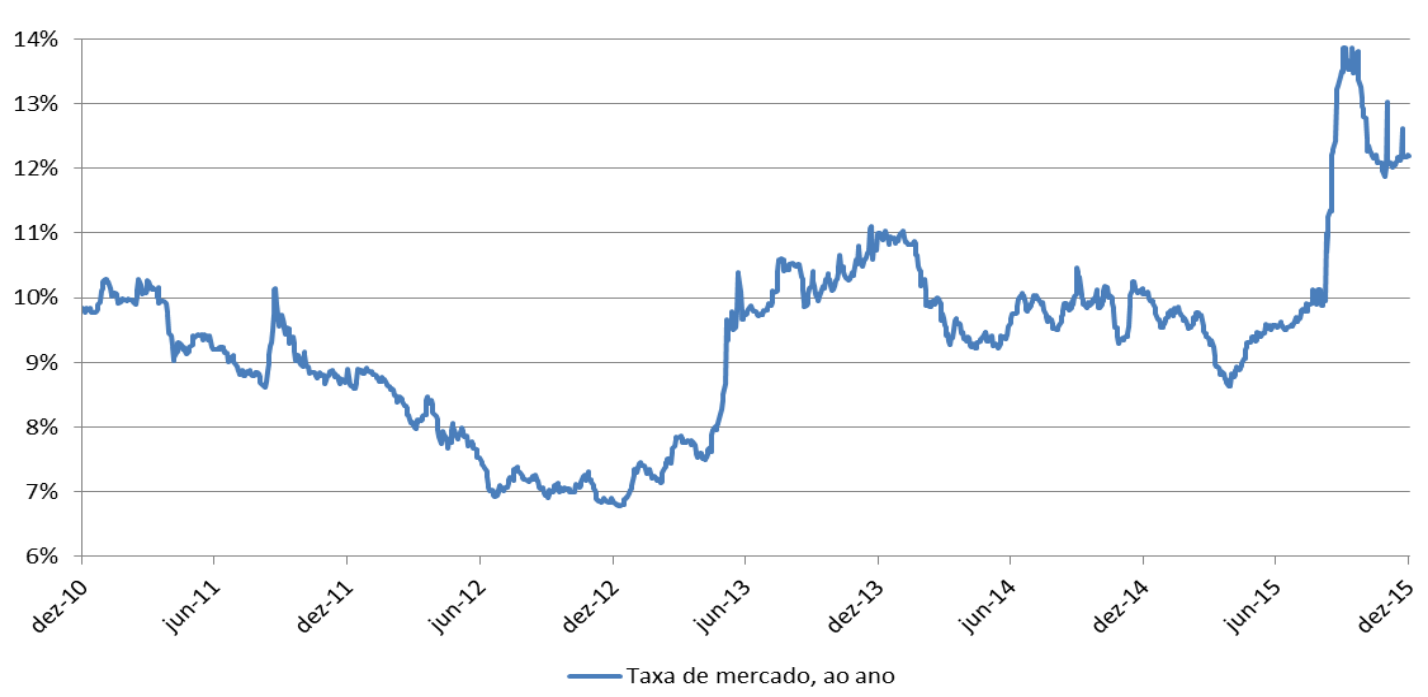

Fonte: Bloomberg.

\subsubsection{Estoque agrupado da DPF}

A partir desse ponto, inicia-se a análise da trajetória do estoque agregado de cada uma das siglas estudadas.

Gráfico 33 - Estoque da LTN, em valores de mercado e na curva.

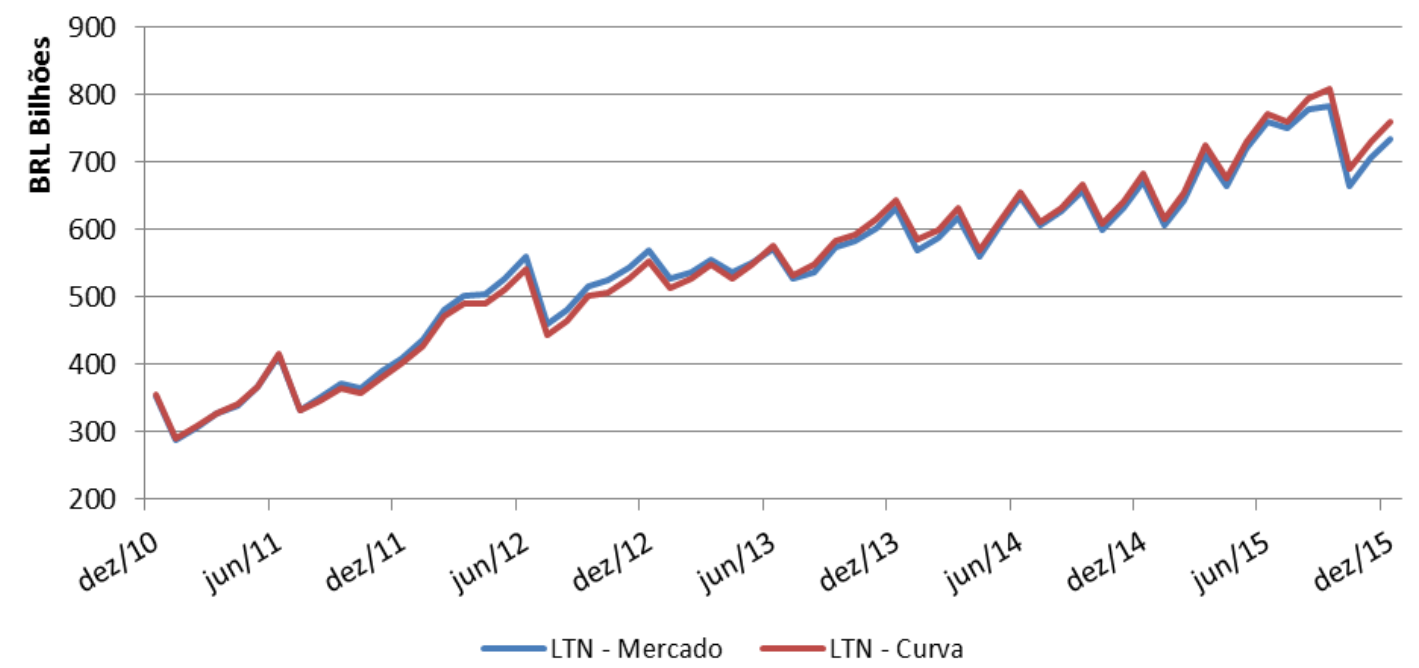

Fonte: Autor, 2016.

\section{RMSE $=2,09 \%$}

Assim como observado na análise individual dos títulos LTN 010414 e LTN 010116, o estoque a preços de mercado permanece acima do estoque pelos preços na curva até maio de 
2013, quando as taxas de mercado se elevaram e inverteram essa relação. É possível verificar ainda reduções bruscas do estoque geradas pelos vencimentos dos títulos, que acontecem geralmente a cada trimestre.

Gráfico 34 - Estoque da NTN-F, em valores de mercado e na curva.

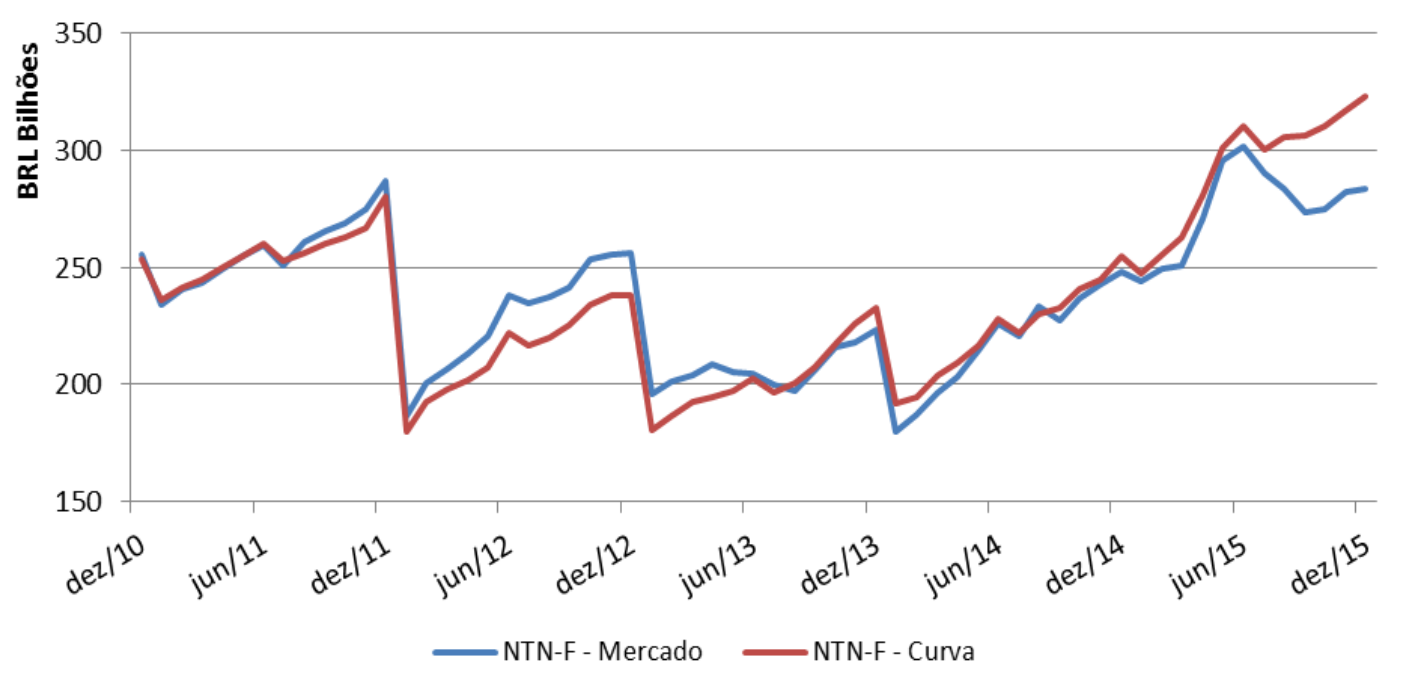

Fonte: Autor, 2016.

\section{RMSE $=\mathbf{5 , 1 6 \%}$}

O comportamento do estoque da NTN-F, apresentado no Gráfico 34, se assemelha ao comportamento dos estoques da LTN e da NTN-B no que se refere à comparação entre estoques a valores de mercado e pelos preços na curva, com os preços de mercado permanecendo acima da série de preços na curva até 2013, quando as taxas de mercado apresentaram aumento e inverteram essa relação.

As quedas abruptas nos meses de janeiro são explicadas pelos vencimentos dos títulos NTN-F 010112, NTN-F 010113, NTN-F 010114 e NTN-F 010115, este último em menor grau devido à reduzida quantidade deste título em mercado. 
Gráfico 35 - Estoque da NTN-B, em valores de mercado e na curva.

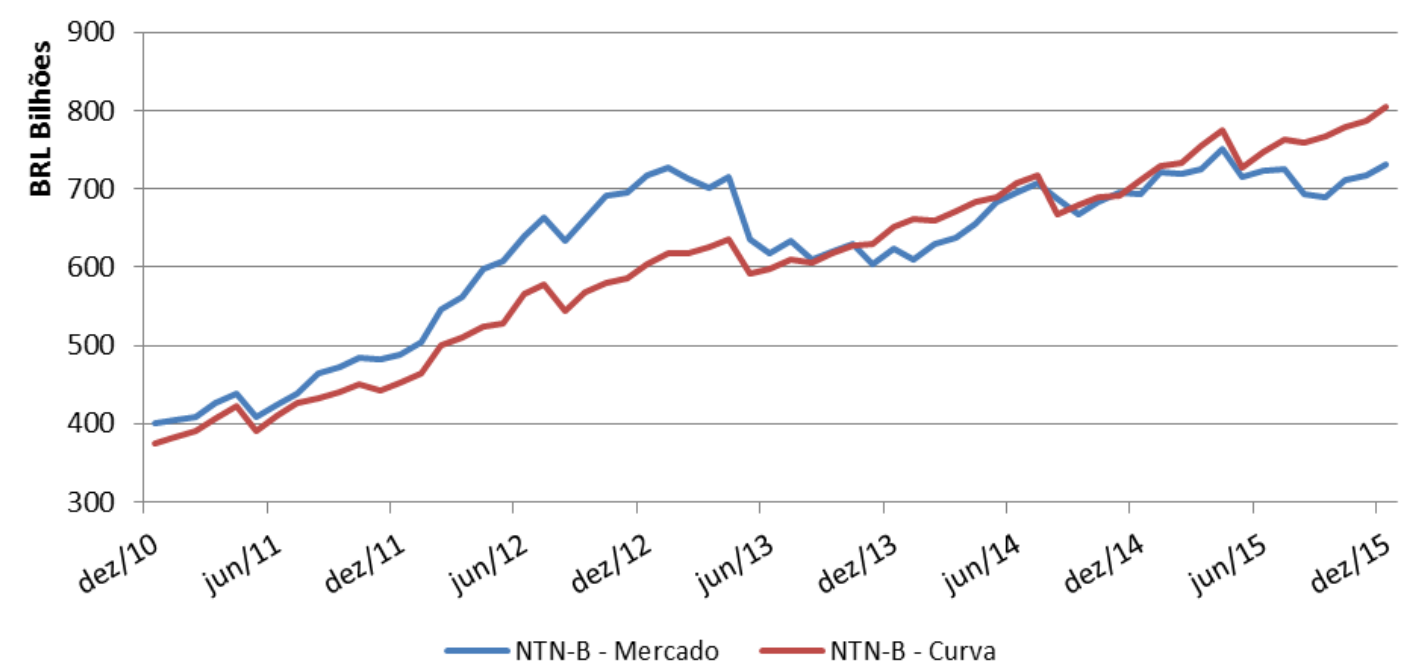

Fonte: Autor, 2016.

\section{$\mathrm{RMSE}=\mathbf{7 , 9 9 \%}$}

O Gráfico 35 mostra estoques a preços de mercado da NTN-B superiores aos estoques pelos preços na curva até outubro de 2013. Deve-se destacar ainda que as diferenças entre os estoques apurados pelas duas metodologias se acentuam no segundo semestre de 2015, comportamento similar ao verificado nos estoques da LTN e da NTN-F.

\section{Gráfico 36 - Estoque da LFT, em valores de mercado e na curva.}

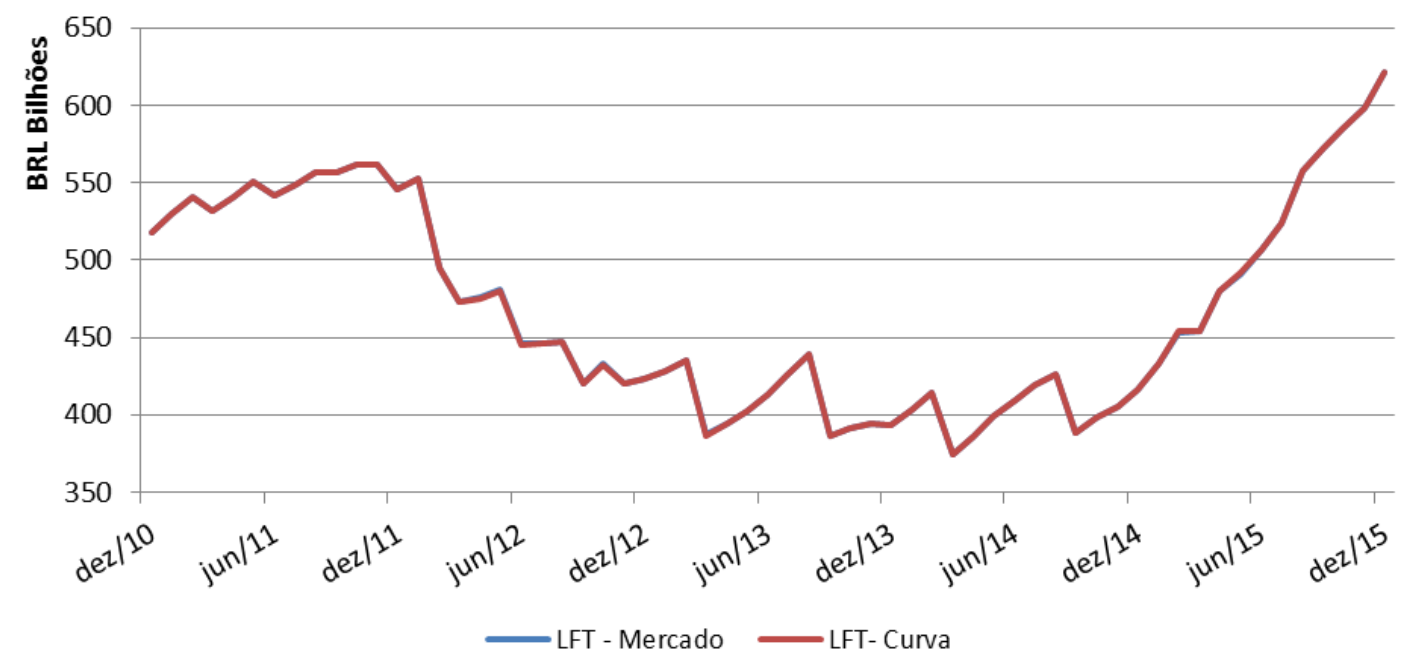

Fonte: Autor, 2016.

\section{$\mathrm{RMSE}=\mathbf{0 , 0 5 \%}$}


A análise do Gráfico 36 aponta para um alinhamento entre os estoques da LFT calculados pelas duas metodologias durante todo o período estudado, refletindo o resultado apurado na análise individual dos títulos. Vale destacar o crescimento acentuado do estoque desta sigla a partir de outubro de 2014.

\section{Gráfico 37 - Estoque dos bônus Euro, em valores de mercado e na curva.}

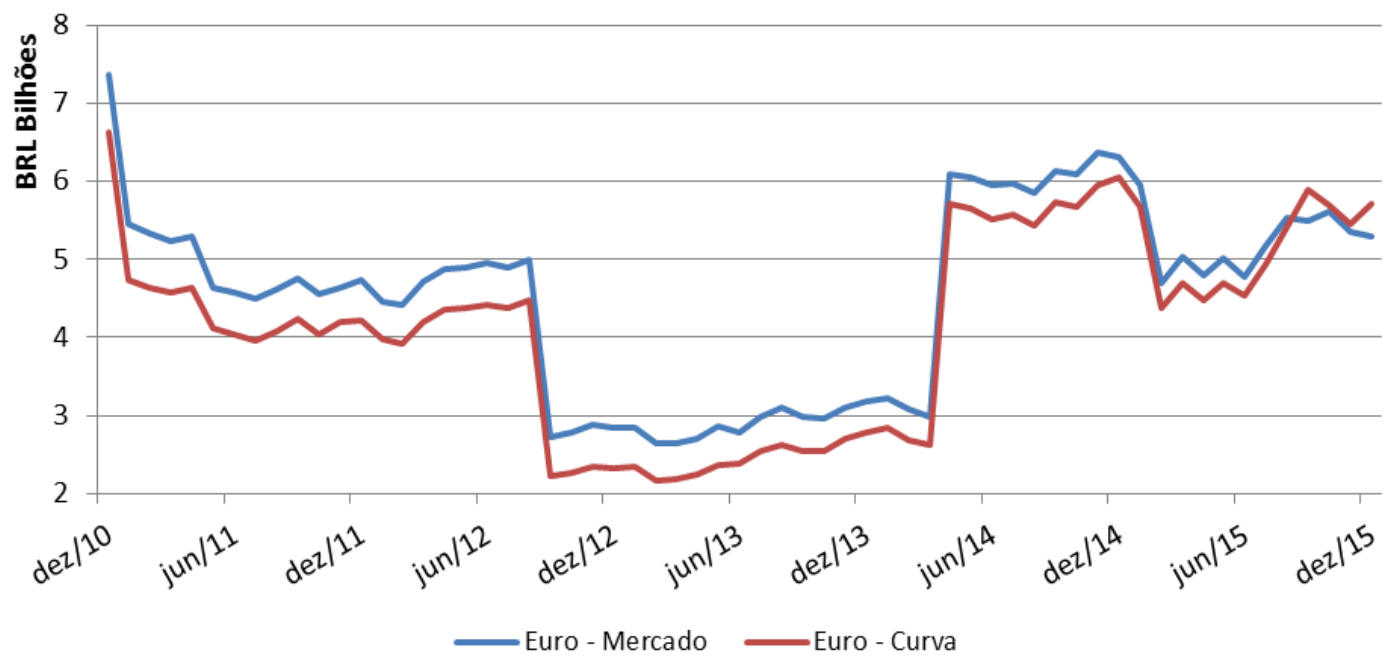

Fonte: Autor, 2016.

\section{RMSE $=11,59 \%$}

Os gráficos 37 e 38 mostram que os estoques a valores de mercado dos bônus Euro e Global, respectivamente, se mantiveram acima dos apurados pelos preços na curva durante quase todo o período estudado, se invertendo apenas no segundo semestre de 2015.

Ainda em relação ao Gráfico 37, é possível observar quedas acentuadas devido aos vencimentos dos bônus Euro 2011, Euro 2012 e Euro 2015, assim como um aumento significativo em virtude da emissão do Euro 2021, em abril de 2014. 


\section{Gráfico 38 - Estoque dos bônus Global, em valores de mercado e na curva.}

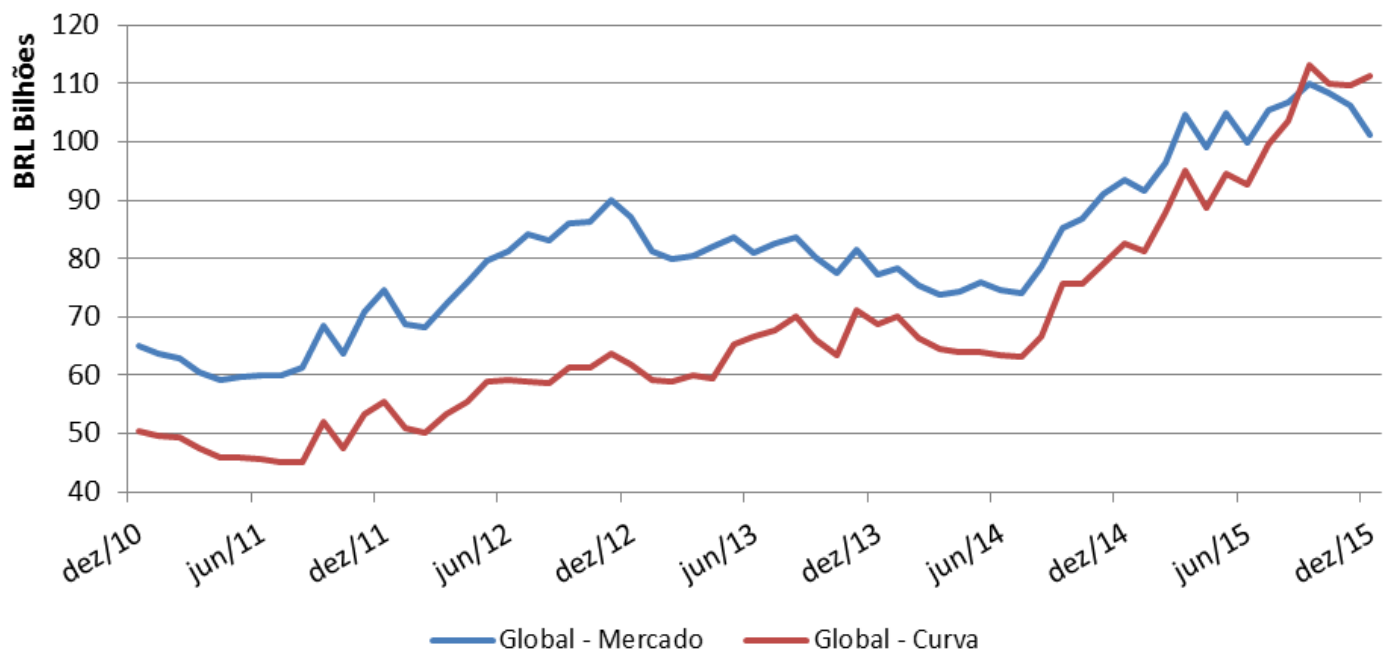

Fonte: Autor, 2016.

RMSE $=20,09 \%$

Gráfico 39 - Estoque dos bônus Global BRL, em valores de mercado e na curva.

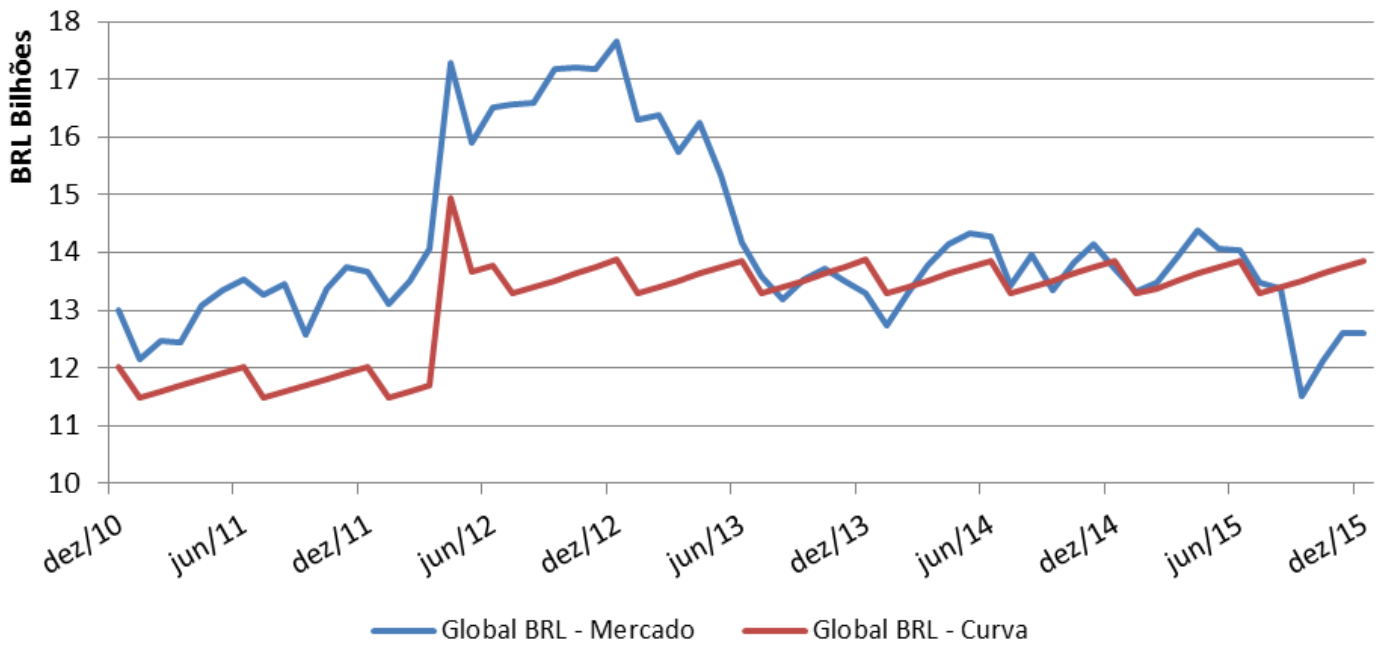

Fonte: Autor, 2016.

\section{RMSE $=\mathbf{1 0 , 8 8 \%}$}

O Gráfico 39, referente à trajetória do estoque da sigla Global BRL, mostra um comportamento similar àquele observado no estoque dos títulos da DPMFi, com os estoques a valores de mercado acima dos valores de estoque pela curva, se invertendo a partir do segundo semestre de 2013 com a elevação das taxas de mercado. $\mathrm{O}$ aumento acentuado dos estoques em 
abril de 2012 se deve à emissão do Global BRL 2024, única emissão desta sigla no período analisado.

Por fim, o Gráfico 40 apresenta o comportamento do estoque agregado da $\mathrm{DPF}^{15}$, que representa o somatório dos estoques das sete siglas incluídas no estudo, calculado pelas duas metodologias de apuração. Os desvios verificados do estoque apurado pela curva em relação ao estoque a preços de mercado durante o período analisado atingiram nível máximo, de 8,87\%, em outubro de 2012, enquanto o RMSE registrado foi de 4,33\%.

\section{Gráfico 40 - Estoque agregado da DPF, em valores de mercado e na curva.}

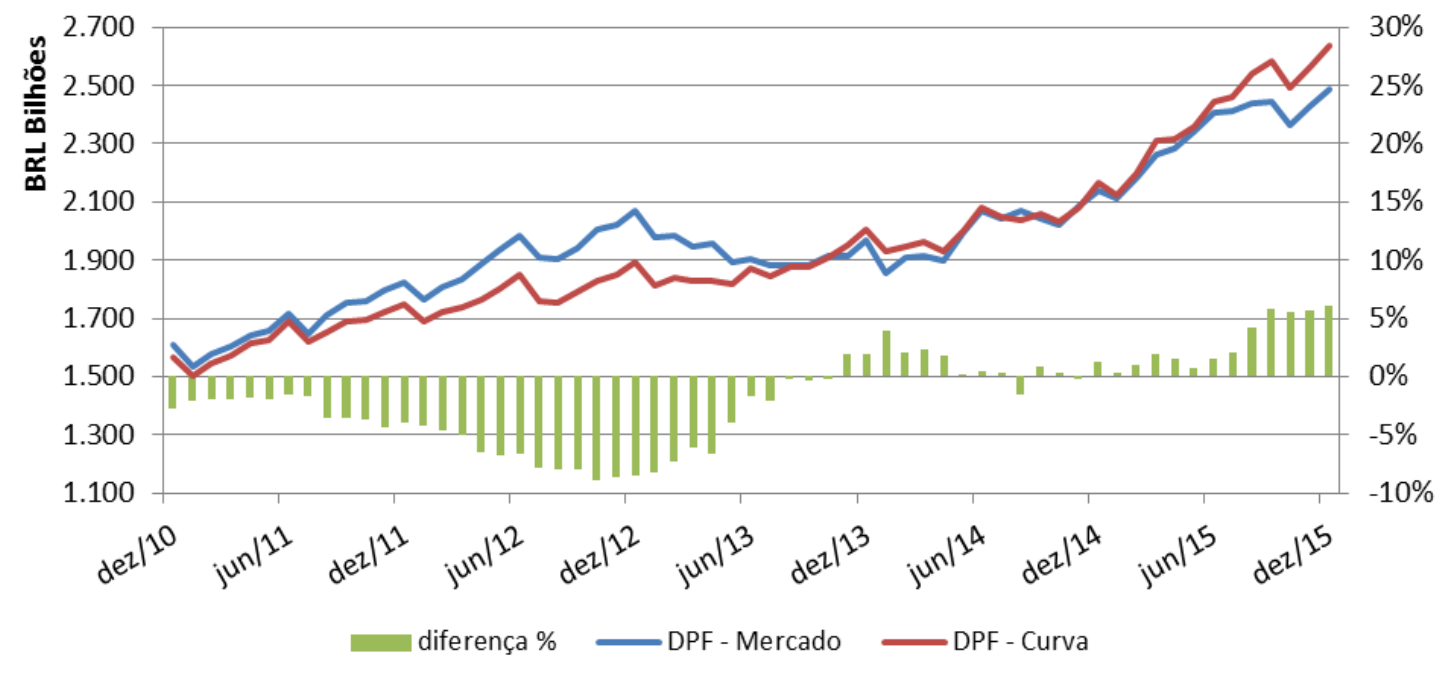

Fonte: Autor, 2016.

\section{RMSE $=4,33 \%$}

\subsubsection{Análise das variáveis que explicam o RMSE do preço na curva em relação ao preço de mercado}

A etapa seguinte da pesquisa teve o intuito de identificar as variáveis que explicam os resultados de RMSE verificados entre os preços na curva e os preços de mercado dos títulos públicos. Nesse sentido, foi realizada uma regressão múltipla tendo como variável dependente o RMSE. O primeiro modelo de regressão foi construído utilizando como variáveis explicativas o desvio padrão das taxas de mercado no período analisado em relação à primeira taxa de emissão dos títulos e a duration dos títulos no início da análise, além das características de

\footnotetext{
${ }^{15}$ Considerando apenas as siglas incluídas no estudo, as quais representam aproximadamente $95 \%$ do estoque total da DPF.
} 
indexação dos títulos como variáveis dummy (taxa flutuante, índice de preços, prefixada e dólar). A Tabela 3 mostra de forma sintetizada os resultados obtidos.

Tabela 3 - Resultados da análise de regressão múltipla $-1^{\circ}$ modelo

\begin{tabular}{cc}
\hline Variável explicativa & Valor $\boldsymbol{p}$ \\
\hline Desvio-padrão & $\mathbf{0 , 0 0 5 3}$ \\
Duration & $\mathbf{0 , 0 0 0 0}$ \\
Dólar & $\mathbf{0 , 0 8 2 7}$ \\
Flutuante & $\mathbf{0 , 8 5 1 6}$ \\
Prefixado & $\mathbf{0 , 7 9 5 2}$ \\
Índice de preços & $\mathbf{0 , 5 0 9 5}$ \\
\hline Estatística F & $\mathbf{0 , 0 0 0 0 0 0}$ \\
R-Quadrado ajustado & $\mathbf{7 1 , 8 1 \%}$ \\
Critério de Akaike & $\mathbf{- 2 , 9 6 0 8 6 4}$ \\
Critério de Schwarz & $\mathbf{- 2 , 7 9 6 5 0 1}$ \\
Critério de Hannan-Quinn & $\mathbf{- 2 , 8 9 4 1 2 8}$ \\
\hline
\end{tabular}

Fonte: Autor, 2016.

A partir desses resultados, um novo modelo foi construído, desta vez incluindo as variáveis explicativas que apresentaram valor $p<0,05$. Apesar de ter sido obtido um valor $p$ de 0,0827 para a variável dummy "dólar", superior ao valor de $\alpha$ estabelecido para o teste, optouse por testá-la no segundo modelo de regressão por apresentar o valor mais significante dentre esse grupo de variáveis. Nesse sentido, as demais variáveis dummy (taxa flutuante, índice de preços e prefixada) foram excluídas dessa segunda análise por apresentarem valor $p$ não significativo.

A Tabela 4 mostra os resultados obtidos pelo segundo modelo de regressão.

Tabela 4 - Resultados da análise de regressão múltipla $-2^{\circ}$ modelo

\begin{tabular}{cc}
\hline Variável explicativa & Valor $\boldsymbol{p}$ \\
\hline Desvio-padrão & $\mathbf{0 , 0 0 0 1}$ \\
Duration & $\mathbf{0 , 0 0 0 0}$ \\
Dólar & $\mathbf{0 , 0 0 8 2}$ \\
\hline Estatística F & $\mathbf{0 , 0 0 0 0 0 0}$ \\
R-Quadrado ajustado & $\mathbf{7 2 , 0 1 \%}$ \\
Critério de Akaike & $\mathbf{- 2 , 9 9 2 1 0 5}$ \\
Critério de Schwarz & $\mathbf{- 2 , 8 9 8 1 8 3}$ \\
Critério de Hannan-Quinn & $\mathbf{- 2 , 9 5 3 9 7 0}$ \\
\hline
\end{tabular}

Fonte: Autor, 2016. 
$\mathrm{O}$ aumento do $\mathrm{R}^{2}$ Ajustado e da estatística $\mathrm{F}$, bem como a redução dos critérios de informação, evidenciam que o segundo modelo é estatisticamente mais bem ajustado que o primeiro para explicar o RMSE do preço na curva em relação ao preço de mercado.

$\mathrm{O}$ teste $\mathrm{F}$ de significância global do modelo apresentou resultado de aproximadamente zero, mostrando que há evidência estatística de que o modelo é adequado para explicar o RMSE do preço na curva em relação ao preço de mercado dos títulos.

Já o teste de significância de cada uma das variáveis explicativas resultou em um valor $p$ de 0,0001 para o desvio padrão das taxas de mercado no período analisado em relação à primeira taxa de emissão dos títulos, enquanto o valor $p$ da duration dos títulos no início da análise foi de aproximadamente zero. A indexação ao dólar, incluída como variável dummy, apresentou valor $p$ de 0,0082 . Esses valores, inferiores ao parâmetro $\alpha$ estabelecido de 0,05 , permitem concluir que há evidência estatística de que essas variáveis estão fortemente relacionadas ao RMSE.

Obteve-se ainda a equação do RMSE estimado em função dos regressores, apresentada a seguir. Os sinais positivos dos coeficientes obtidos das variáveis explicativas indicam que essas variáveis e o RMSE dos títulos no período analisado estão positivamente relacionados.

$$
\hat{y}=-0,050912+1,631814 \cdot x_{1}+0,013018 \cdot x_{2}+0,065670 \cdot x_{3}
$$

Onde:

$\hat{y}$ : valor estimado de RMSE;

$x_{1}$ : desvio padrão das taxas de mercado no período analisado em relação à primeira taxa de emissão do título;

$x_{2}$ : duration do título;

$x_{3}$ : indexação ao dólar.

Por fim, a interpretação do valor do $\mathrm{R}^{2}$ Ajustado do modelo aponta para a conclusão que essas três variáveis juntas respondem por aproximadamente $72 \%$ do comportamento do RMSE do preço na curva em relação ao preço de mercado, o que pode ser considerado um alto poder explicativo. 


\subsubsection{Indicadores da DPF}

A partir dos resultados obtidos na precificação dos títulos é possível comparar o comportamento dos indicadores tradicionais de risco e custo da DPF, respeitando-se o padrão metodológico adotado na apuração do estoque da dívida pública.

\subsubsection{Composição}

Uma das informações mais relevantes quanto à qualidade do endividamento se refere à composição de seu estoque em categorias, de acordo com os diferentes tipos de remuneração dos títulos da DPF, os quais representam classes de risco distintas. São elas: prefixados (LTN, NTN-F e Global BRL), índice de preços (NTN-B), taxa flutuante (LFT) e câmbio (Euro e Global).

O Gráfico 41 mostra a trajetória da participação percentual de cada uma dessas categorias em relação ao estoque total, considerando as duas metodologias de precificação dos títulos: em valores de mercado e na curva, enquanto a Tabela 5 apresenta os valores de RMSE obtidos, em pontos percentuais.

\section{Gráfico 41 - Evolução da composição da DPF}

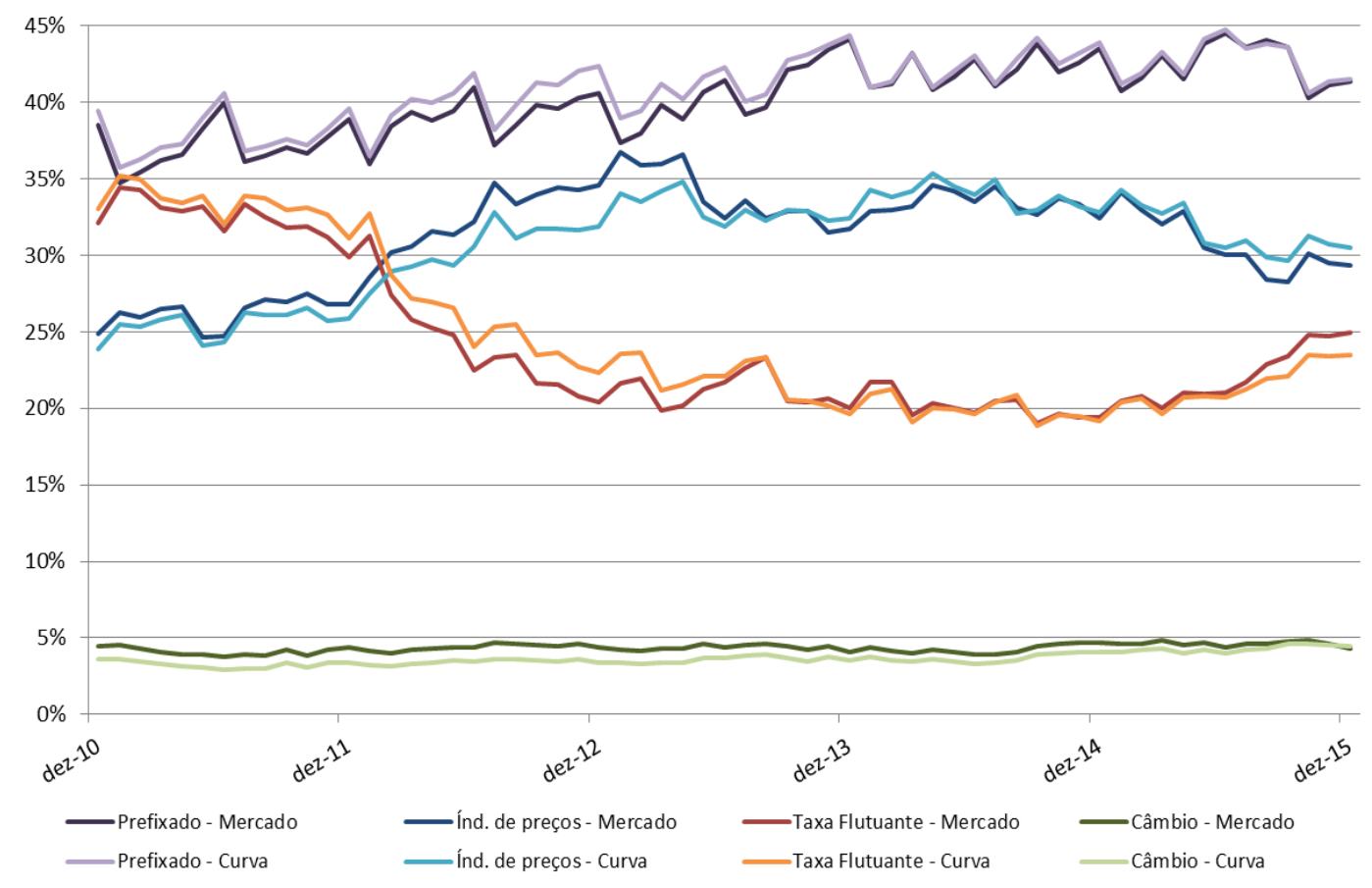

Fonte: Autor, 2016. 
Tabela 5 - Resultados de RMSE da participação de cada categoria, em pontos percentuais

\begin{tabular}{cc}
\hline Indexador & $\begin{array}{c}\text { RMSE participação no estoque } \\
\text { (pontos percentuais) }\end{array}$ \\
\hline Prefixado & 0,82 \\
Índice de preços & 1,26 \\
Taxa flutuante & 1,07 \\
Câmbio & 0,74 \\
\hline
\end{tabular}

Fonte: Autor, 2016.

No que se refere ao comparativo entre a participação relativa de cada categoria mensurada pelas diferentes metodologias, percebe-se que a trajetória dos títulos remunerados por índice de preços reflete o comportamento observado no estoque da NTN-B, com a participação apurada pelos preços de mercado permanecendo acima da apurada pelos preços na curva até 2013, quando as taxas de mercado se elevam e invertem essa relação.

Observa-se um descolamento das linhas que marcam a participação dos títulos prefixados e indexados a taxa flutuante, considerando as duas metodologias de apuração. Em virtude de a composição apresentar a parcela de cada categoria em relação ao estoque total, à medida que a participação das NTN-B, mais sensíveis às flutuações das taxas de mercado, apresenta distanciamento entre os valores apurados pelos diferentes métodos de apuração, a participação dos títulos prefixados e indexados a taxa flutuante nas duas metodologias apresenta resultado inverso, como compensação ao comportamento das NTN-B.

\subsubsection{Prazo médio, Duration e ATM}

Os indicadores de maturidade do endividamento, que recebem diferentes nomenclaturas de acordo com a metodologia adotada, foram analisados de maneira agregada, por sigla. Os resultados da análise comparativa entre o prazo médio, calculado usando como taxa de desconto dos fluxos do título a taxa média das emissões, a duration, que utiliza a taxa de mercado como taxa de desconto, e o ATM, que utiliza os valores de face, estão sintetizados na Tabela 6 . As diferenças entre os resultados obtidos a partir das diferentes metodologias foram mensuradas com a utilização do RMSE. 
Tabela 6 - Resultados de prazo médio, duration e ATM

\begin{tabular}{ccc}
\hline & Sigla & RMSE prazo médio \\
\hline \multirow{3}{*}{ DPMFi } & LTN & $2,46 \%$ \\
& NTN-F & $3,57 \%$ \\
& LFT & $0,02 \%$ \\
NTTN-B & $8,49 \%$ \\
\hline \multirow{2}{*}{ DPMFe } & Euro & $6,37 \%$ \\
& Global & $6,17 \%$ \\
\hline
\end{tabular}

Fonte: Autor, 2016.

O cálculo do ATM apresenta valores superiores aos dos demais indicadores de maturidade, uma vez que não leva em consideração os pagamentos de cupom de juros e se baseia nos valores de face dos títulos, sem a devido rigor ao conceito de valor do dinheiro no tempo. Já o prazo médio e a duration se alteram de acordo com a taxa de desconto usada na precificação dos títulos. As flutuações das taxas de mercado provocam variações nos preços dos títulos, como visto anteriormente, sendo os vencimentos mais longos mais sensíveis a tais flutuações. Neste sentido, quanto maior a taxa de desconto, menor o resultado do indicador.

Se por um lado tem-se uma redução do valor de mercado do estoque da dívida pública em função de um aumento das taxas de mercado, por outro é possível observar uma piora da qualidade do endividamento pela redução da sua duration. Essa análise será aprofundada na capítulo 6 (discussão).

Os gráficos a seguir mostram a evolução do prazo médio, duration e ATM de cada uma das siglas, entre dezembro de 2010 e dezembro de 2015. 


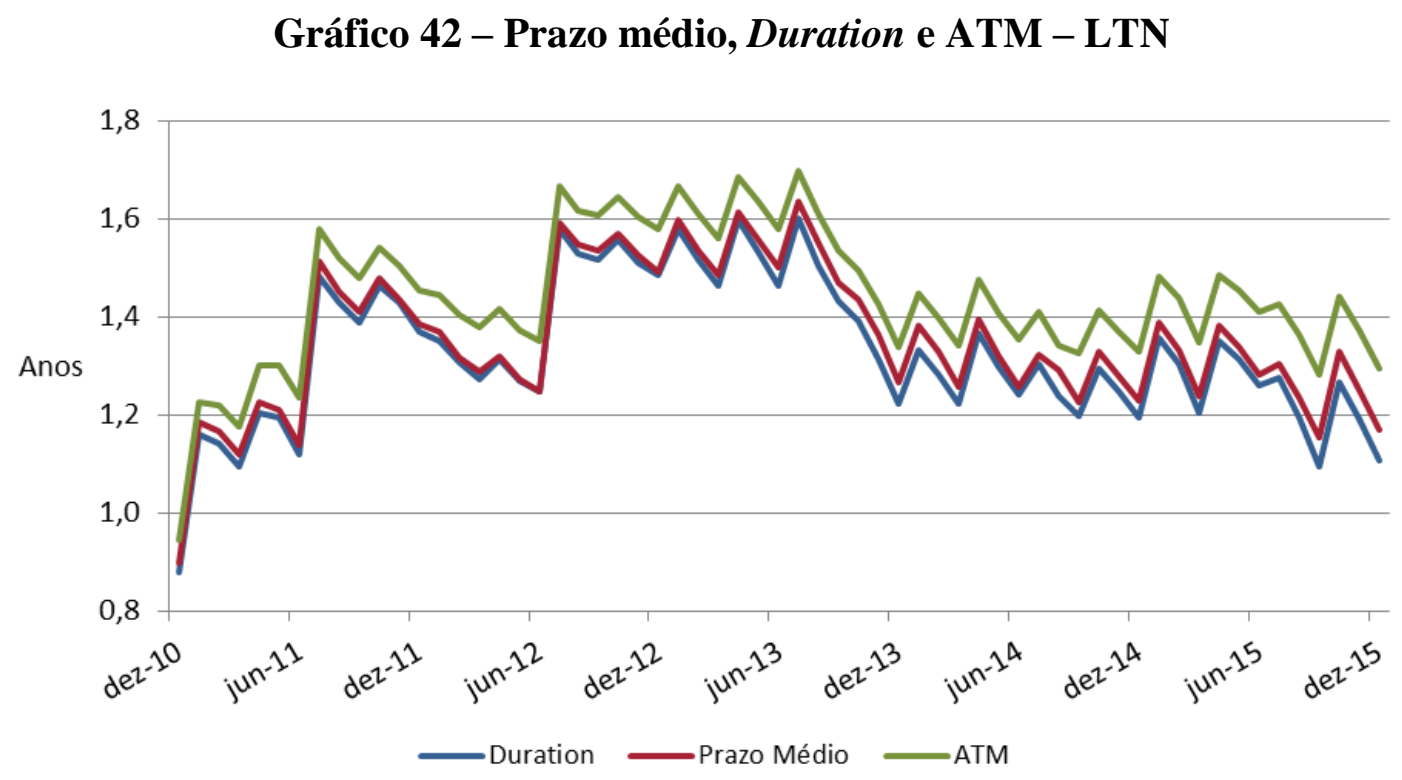

Fonte: Autor, 2016.

\section{RMSE $=\mathbf{2 , 4 6 \%}$}

Os indicadores prazo médio e duration da sigla LTN se mantiveram próximos durante quase todo o período analisado, o que é evidenciado pelo RMSE de 2,46\%, segundo menor RMSE dentre as siglas estudadas. Entretanto, as diferenças entre os valores encontrados pelas duas metodologias se elevaram a partir do segundo semestre de 2013, em virtude do aumento das taxas de mercado.

\section{Gráfico 43 - Prazo médio, Duration e ATM - NTN-F}

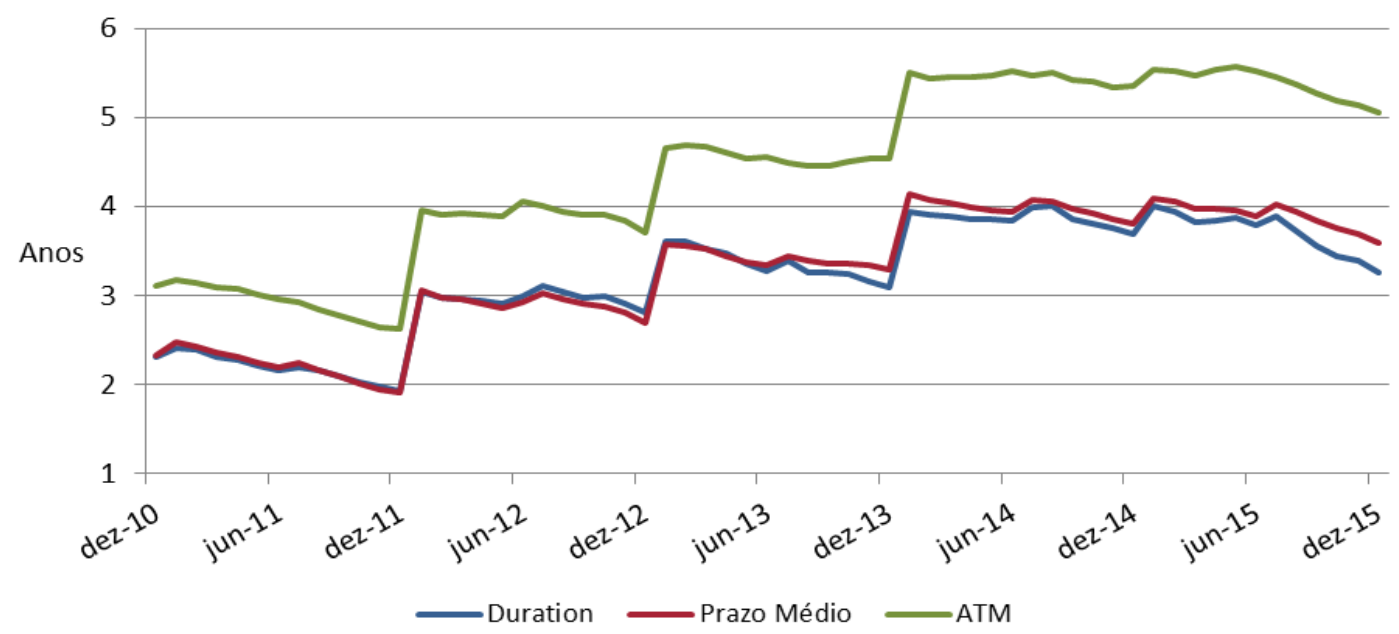

Fonte: Autor, 2016. 


\section{RMSE $=\mathbf{3 , 5 7 \%}$}

A trajetória dos indicadores prazo médio, duration e ATM pode ser vista no Gráfico 43. O RMSE do prazo médio em relação a duration foi de 3,57\%, superior ao resultado das LTN, mostrando a maior sensibilidade do preço das NTN-F às elevações das taxas de mercado ocorridas principalmente no segundo semestre de 2013.

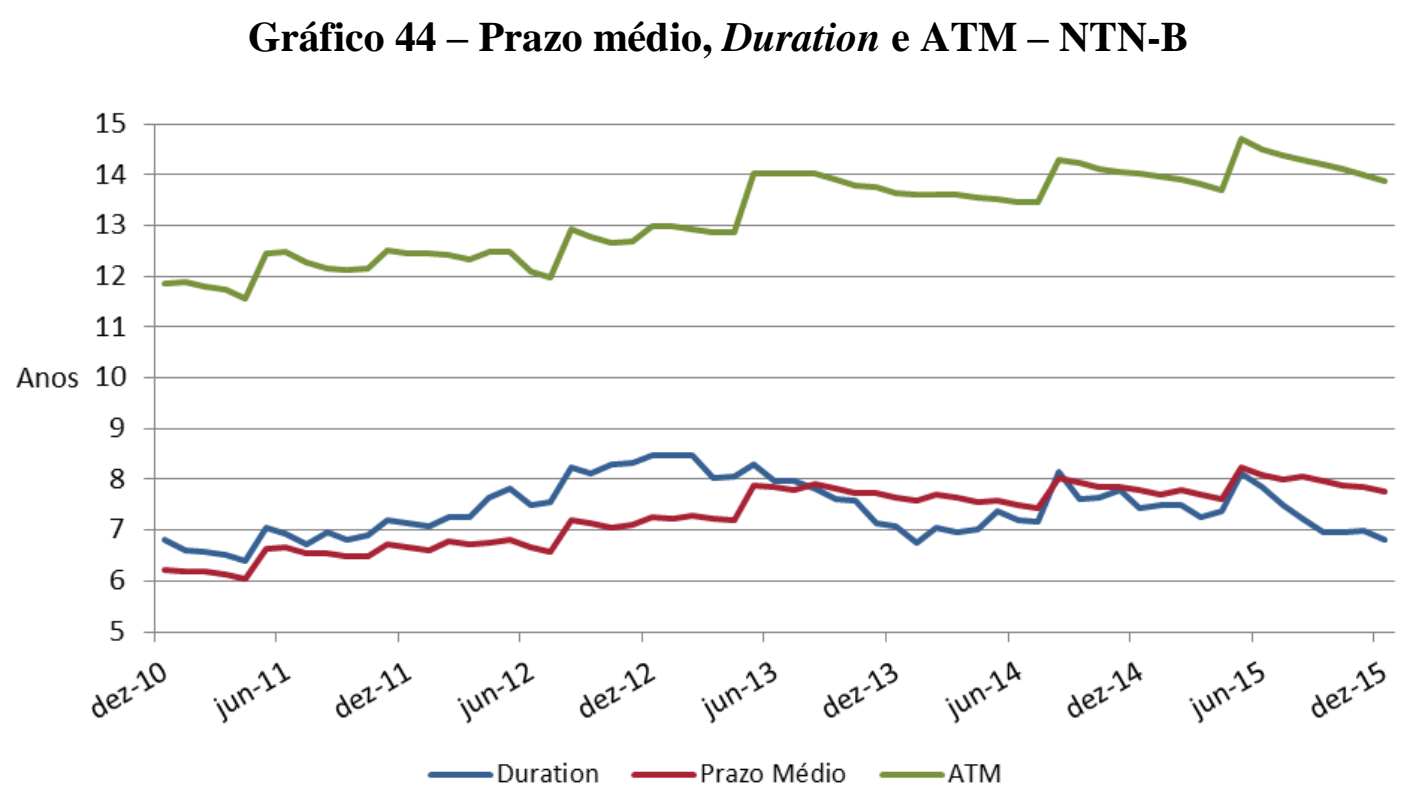

Fonte: Autor, 2016.

\section{RMSE $=\mathbf{8 , 4 9 \%}$}

A análise do Gráfico 44 mostra a duration dos títulos NTN-B acima dos valores do prazo médio. Este comportamento dos indicadores se inverte a partir do segundo semestre de 2013, de forma similar ao comportamento observado nas NTN-F. Mais uma vez, deve-se destacar o alinhamento encontrado entre os resultados da precificação dos títulos e seus indicadores, o que evidencia o impacto das diferentes metodologias de apuração no cálculo dos indicadores. Neste sentido, de maneira similar à ocorrida na análise do estoque, a NTN-B registrou o maior RMSE do prazo médio em relação a duration dentre as siglas da DPMFi, de $8,49 \%$. 


\section{Gráfico 45 - Prazo médio, Duration e ATM - LFT}

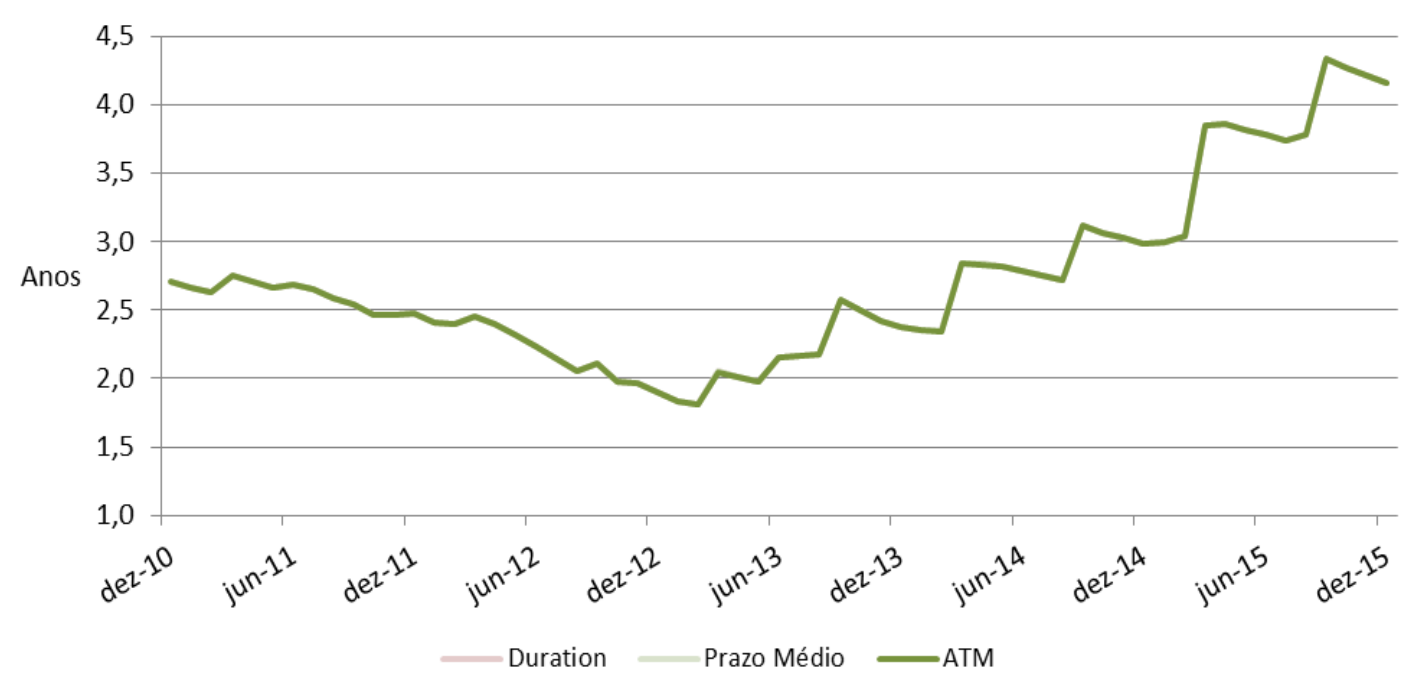

Fonte: Autor, 2016.

\section{$\mathrm{RMSE}=\mathbf{0 , 0 2 \%}$}

Os resultados dos indicadores calculados das LFT pelas diferentes metodologias formaram linhas sobrepostas durante o período estudado, como mostra o Gráfico 45. Este resultado é compatível com aqueles obtidos na precificação desses títulos. Isto pode ser explicado, em primeiro lugar, pelo fato das LFT serem títulos bullet, ou seja, sem pagamento de cupom de juros; ademais, os preços das LFT apurados em valores de mercado, na curva e nominais tiveram o menor RMSE entre os títulos da DPF, impactando de forma pouco relevante a ponderação no cálculo dos indicadores.

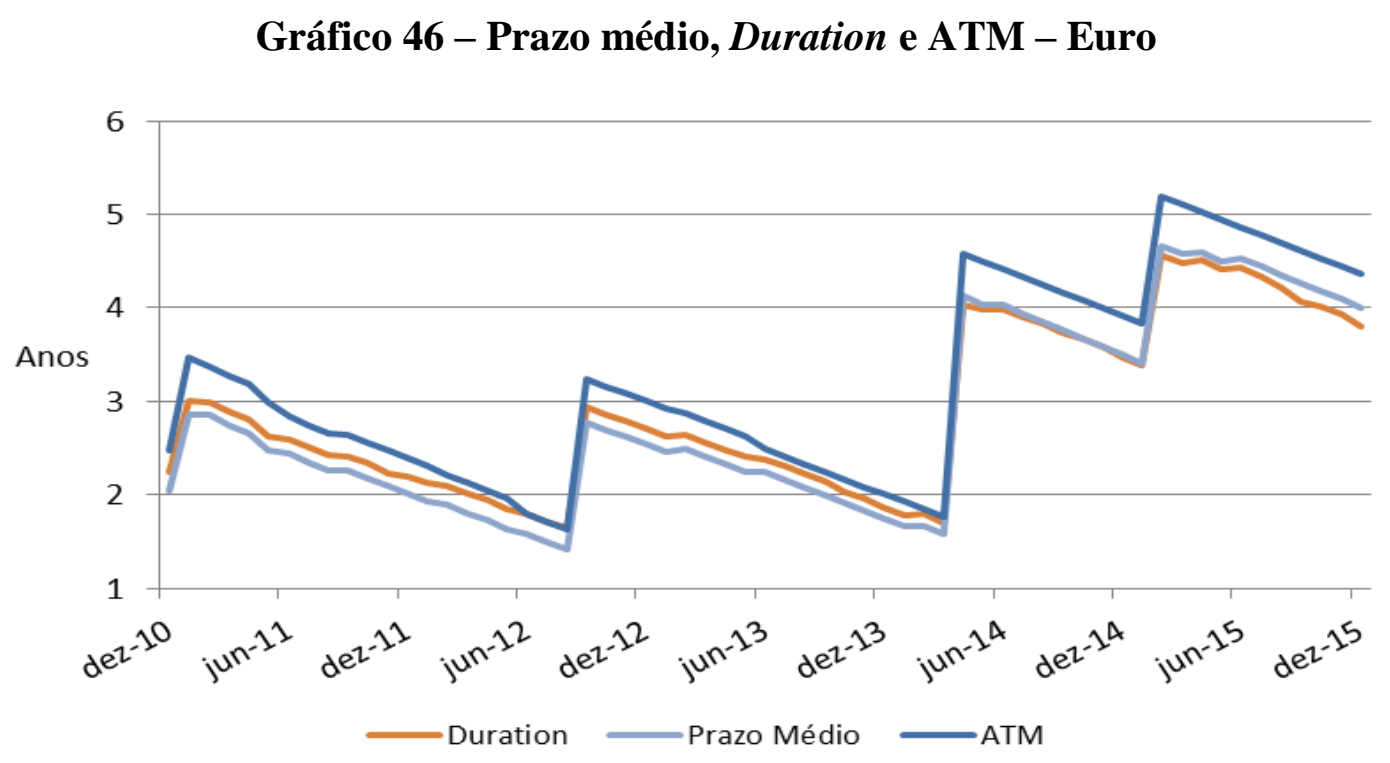

Fonte: Autor, 2016. 


\section{RMSE $=6,37 \%$}

As trajetórias do prazo médio, duration e ATM dos bônus Euro e Global, apresentadas nos Gráficos 46 e 47, apontam para resultados alinhados àqueles obtidos na análise do estoque da dívida pública no que se refere à comparação entre os resultados obtidos pelas diferentes metodologias. A duration se manteve acima dos valores de prazo médio durante quase todo o período estudado. Esta relação se inverteu em 2015 em função da elevação das taxas de mercado.

Ainda sobre o Gráfico 46, pode-se observar elevações bruscas nas trajetórias dos indicadores em virtude dos vencimentos dos títulos e da emissão do bônus Euro 2021, em abril de 2012.

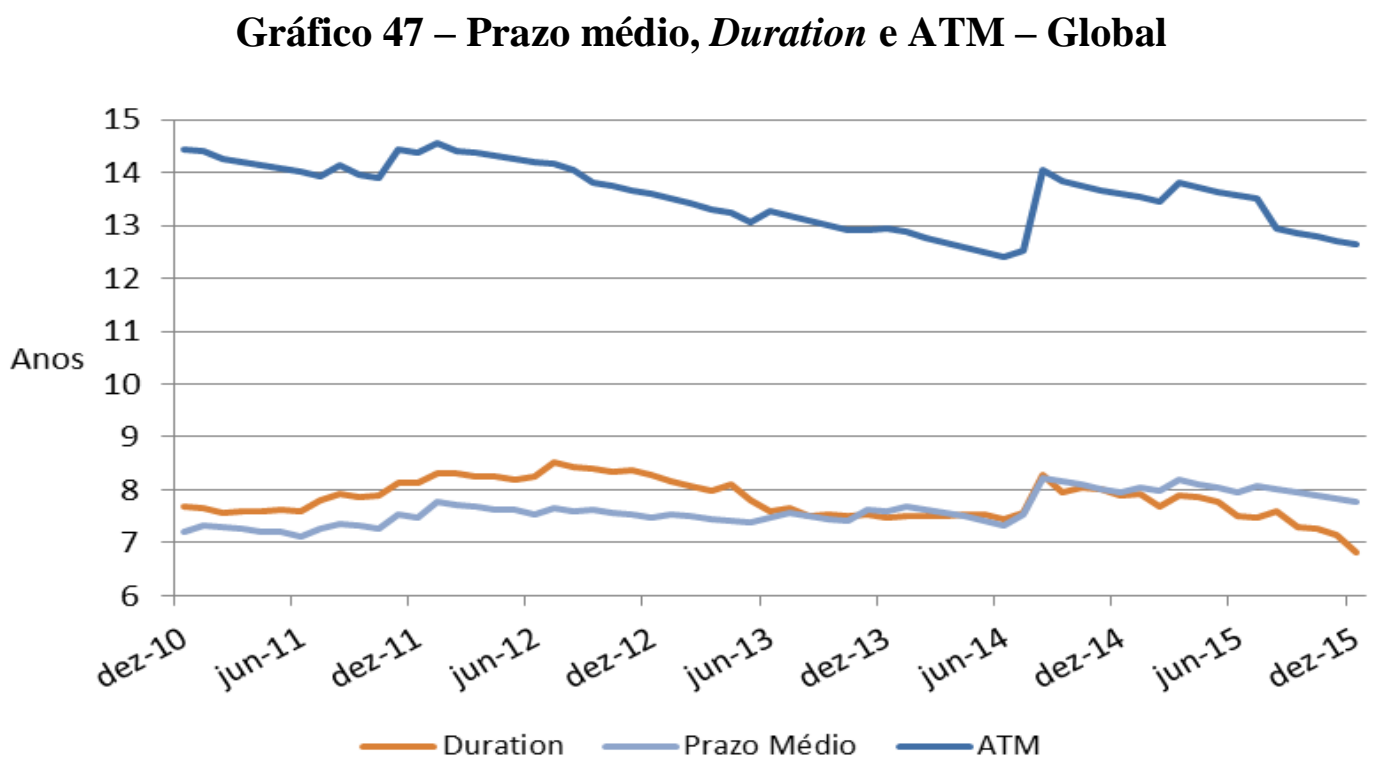

Fonte: Autor, 2016.

RMSE $=6,17 \%$ 
Gráfico 48 - Prazo médio, Duration e ATM - Global BRL

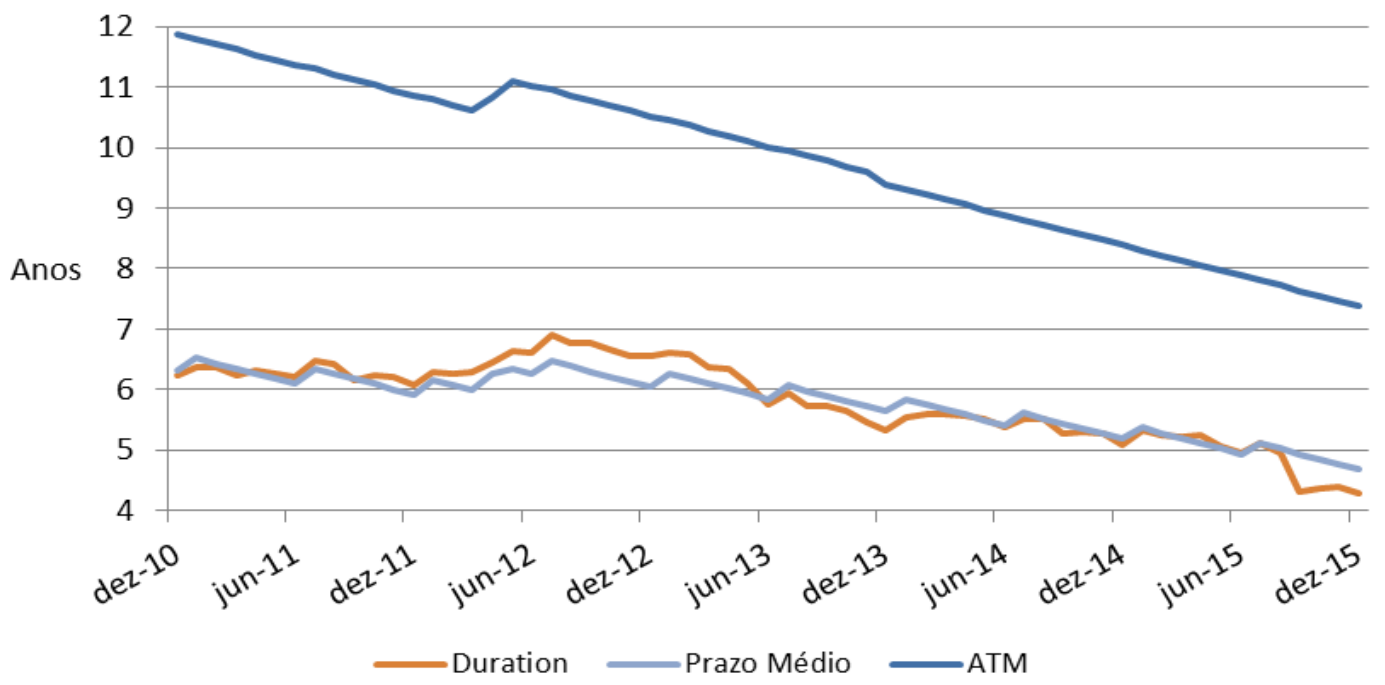

Fonte: Autor, 2016.

\section{RMSE $=\mathbf{4 , 3 5 \%}$}

Assim como observado nas demais siglas, o Gráfico 48 encontra relação com o comportamento dos estoques em valores de mercado e pela curva dos bônus Global BRL, com a duration permanecendo acima do prazo médio até o segundo semestre de 2013. A partir deste ponto, os indicadores oscilam até julho de 2015, quando as taxas voltam a aumentar e levam a duration a níveis abaixo do prazo médio. O aumento dos indicadores em abril de 2012 se deve à emissão do bônus Global BRL 2024, que tem prazo médio superior ao prazo médio da sigla Global BRL.

\subsubsection{Custo médio mensal}

Os cálculos de custo médio mensal, apresentados na Tabela 7, mostram resultados similares àqueles encontrados na precificação dos títulos, uma vez que este indicador capta a taxa de variação do valor dos títulos durante o mês analisado. Neste sentido, o custo médio de um título é afetado pelos mesmos fatores que alteram seu preço: a taxa de rentabilidade e o indexador do título. 
Tabela 7 - Resultados do custo médio mensal dos títulos da DPMFi

(continua)

\begin{tabular}{|c|c|}
\hline Título & $\begin{array}{c}\text { RMSE custo } \\
\text { (pontos percentuais) }\end{array}$ \\
\hline LTN 010111 & - \\
\hline LTN 010411 & 0,03 \\
\hline LTN 010711 & 0,08 \\
\hline LTN 011011 & 0,12 \\
\hline LTN 010412 & 0,20 \\
\hline LTN 010712 & 0,34 \\
\hline LTN 011012 & 0,28 \\
\hline LTN 010113 & 0,55 \\
\hline LTN 010413 & 0,60 \\
\hline LTN 010713 & 0,69 \\
\hline LTN 011013 & 0,12 \\
\hline LTN 010114 & 0,71 \\
\hline LTN 010414 & 0,47 \\
\hline LTN 010714 & 0,35 \\
\hline LTN 011014 & 0,30 \\
\hline LTN 010115 & 0,98 \\
\hline LTN 010415 & 0,59 \\
\hline LTN 010715 & 0,64 \\
\hline LTN 011015 & 0,15 \\
\hline LTN 010116 & 0,87 \\
\hline LTN 010416 & 0,48 \\
\hline LTN 010716 & 1,04 \\
\hline LTN 011016 & 0,65 \\
\hline LTN 010117 & 1,40 \\
\hline LTN 010717 & 1,22 \\
\hline LTN 011017 & 1,38 \\
\hline LTN 010118 & 1,48 \\
\hline LTN 010718 & 1,84 \\
\hline LTN 010119 & 1,90 \\
\hline LTN 010719 & 2,53 \\
\hline LTN & $\mathbf{0 , 5 7}$ \\
\hline NTN-F 010111 & - \\
\hline NTN-F 010112 & 0,16 \\
\hline NTN-F 010113 & 0,52 \\
\hline NTN-F 010114 & 0,76 \\
\hline NTN-F 010115 & 0,93 \\
\hline NTN-F 010117 & 1,42 \\
\hline NTN-F 010118 & 1,51 \\
\hline NTN-F 010119 & 1,90 \\
\hline NTN-F 010121 & 2,41 \\
\hline NTN-F 010123 & 2,73 \\
\hline
\end{tabular}


(continuação)

Título

\begin{tabular}{|c|c|}
\hline Título & $\begin{array}{c}\text { RMSE custo } \\
\text { (pontos percentuais) }\end{array}$ \\
\hline NTN-F 010125 & 3,03 \\
\hline NTN-F & 1,55 \\
\hline LFT 160311 & 0,00 \\
\hline LFT 150611 & 0,00 \\
\hline LFT 210911 & 0,00 \\
\hline LFT 161111 & 0,00 \\
\hline LFT 211211 & 0,00 \\
\hline LFT 070312 & 0,00 \\
\hline LFT 070912 & 0,01 \\
\hline LFT 211112 & 0,01 \\
\hline LFT 070313 & 0,01 \\
\hline LFT 070613 & 0,01 \\
\hline LFT 070913 & 0,02 \\
\hline LFT 181213 & 0,02 \\
\hline LFT 070314 & 0,02 \\
\hline LFT 070914 & 0,02 \\
\hline LFT 070315 & 0,03 \\
\hline LFT 070915 & 0,03 \\
\hline LFT 010316 & 0,04 \\
\hline LFT 070916 & 0,04 \\
\hline LFT 070317 & 0,05 \\
\hline LFT 070917 & 0,06 \\
\hline LFT 010318 & 0,07 \\
\hline LFT 010918 & 0,03 \\
\hline LFT 010319 & 0,02 \\
\hline LFT 010320 & 0,01 \\
\hline LFT 010920 & 0,00 \\
\hline LFT 010321 & 0,03 \\
\hline LFT 010921 & 0,01 \\
\hline LFT & $\mathbf{0 , 0 2}$ \\
\hline NTN-B 150511 & 0,36 \\
\hline NTN-B 151111 & 0,35 \\
\hline NTN-B 150812 & 0,52 \\
\hline NTN-B 150513 & 0,68 \\
\hline NTN-B 150814 & 0,86 \\
\hline NTN-B 150515 & 0,94 \\
\hline NTN-B 150816 & 1,09 \\
\hline NTN-B 150517 & 1,32 \\
\hline NTN-B 150818 & 1,47 \\
\hline NTN-B 150519 & 1,32 \\
\hline NTN-B 150820 & 1,88 \\
\hline NTN-B 150822 & 1,82 \\
\hline NTN-B 150523 & 1,82 \\
\hline NTN-B 150824 & 2,32 \\
\hline
\end{tabular}
(pontos percentuais)

RMSE custo 
(conclusão)

\begin{tabular}{cc}
\hline Título & $\begin{array}{c}\text { RMSE custo } \\
\text { (pontos percentuais) }\end{array}$ \\
\hline NTN-B 150830 & 2,91 \\
NTN-B 150535 & 3,41 \\
NTN-B 150840 & 3,82 \\
NTN-B 150545 & 4,09 \\
NTN-B 150850 & 4,31 \\
NTN-B 150555 & 3,44 \\
NTN-B & $\mathbf{2 , 1 0}$ \\
\hline
\end{tabular}

Fonte: Autor, 2016.

O RMSE do custo médio dos títulos da DPMFi refletiu a volatilidade encontrada nas séries de preços de mercado e pela curva dessas siglas. Observa-se que os títulos mais longos das siglas prefixadas - LTN 010719 e NTN-F 010125 - foram aqueles que apresentaram os resultados mais elevados, de 2,53 e 3,03 pontos percentuais, respectivamente.

Já os títulos da sigla NTN-B foram os papéis que tiveram seus preços mais afetados pelas flutuações das taxas de juros no período analisado e, consequentemente, apresentaram o maior RMSE do custo médio dentre as siglas da DPMFi, de 2,10 pontos percentuais, sendo a NTN-B 150850 o título com maior RMSE, de 4,31 pontos percentuais.

Por outro lado, os títulos LFT apresentaram o menor RMSE, de apenas 0,02 ponto percentual, refletindo os resultados encontrados na precificação do título pelas duas diferentes metodologias, que apontaram a maior proximidade entre seus preços de mercado e na curva dentre as siglas estudadas.

A seguir, são apresentados os gráficos referentes aos resultados obtidos do custo médio mensal de alguns dos títulos analisados.

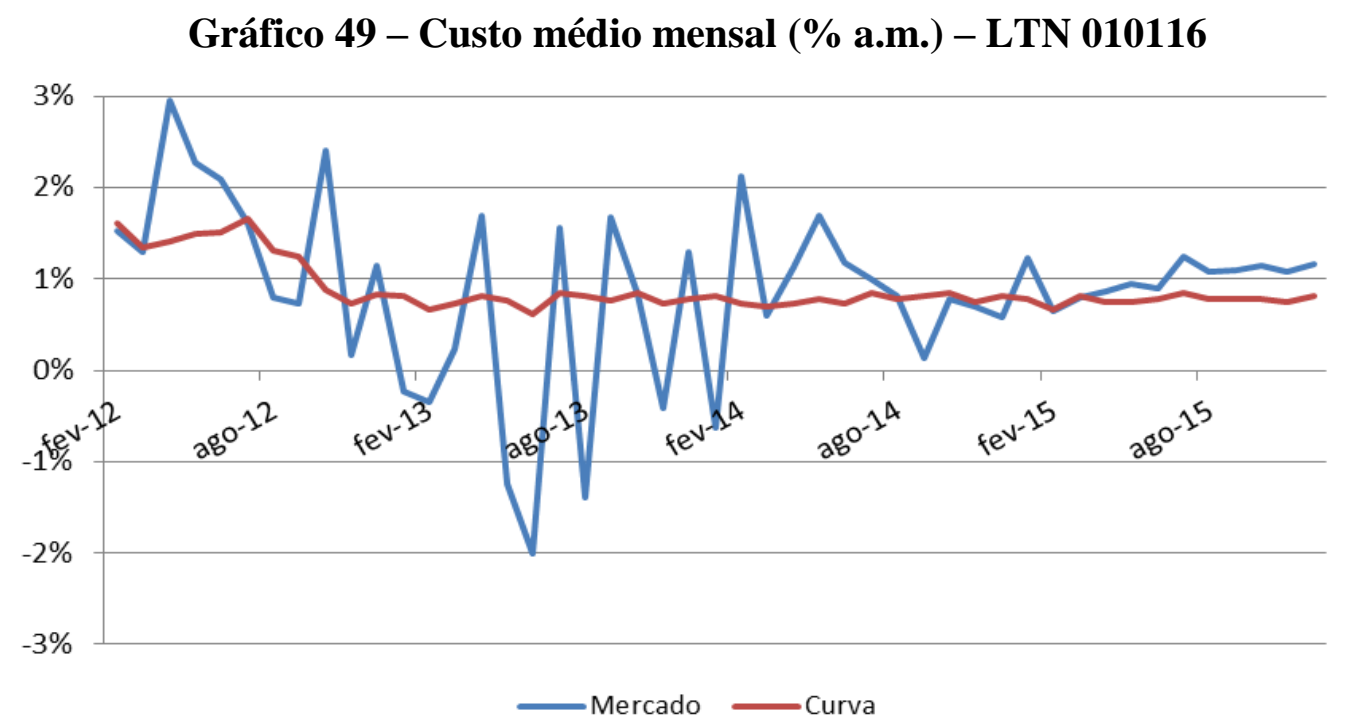

Fonte: Autor, 2016. 


\section{RMSE $=0,87$ ponto percentual}

Os Gráficos 49 e 50 mostram a evolução do custo médio mensal da LTN 010116 e NTN-F 010118, respectivamente, desde a primeira emissão dos títulos, em janeiro de 2012, até dezembro de 2015. É possível verificar que os dois títulos prefixados apresentam resultados similares de custo médio, que representa a taxa de variação do preço dos títulos. O início da trajetória do custo apurado pela curva mostra o impacto de novas emissões. Após esse período, observa-se uma estabilidade deste indicador. Já o custo médio apurado pelos valores de mercado é um reflexo da flutuação intensa de seus preços de mercado.

\section{Gráfico 50 - Custo médio mensal (\% a.m.) - NTN-F 010118}

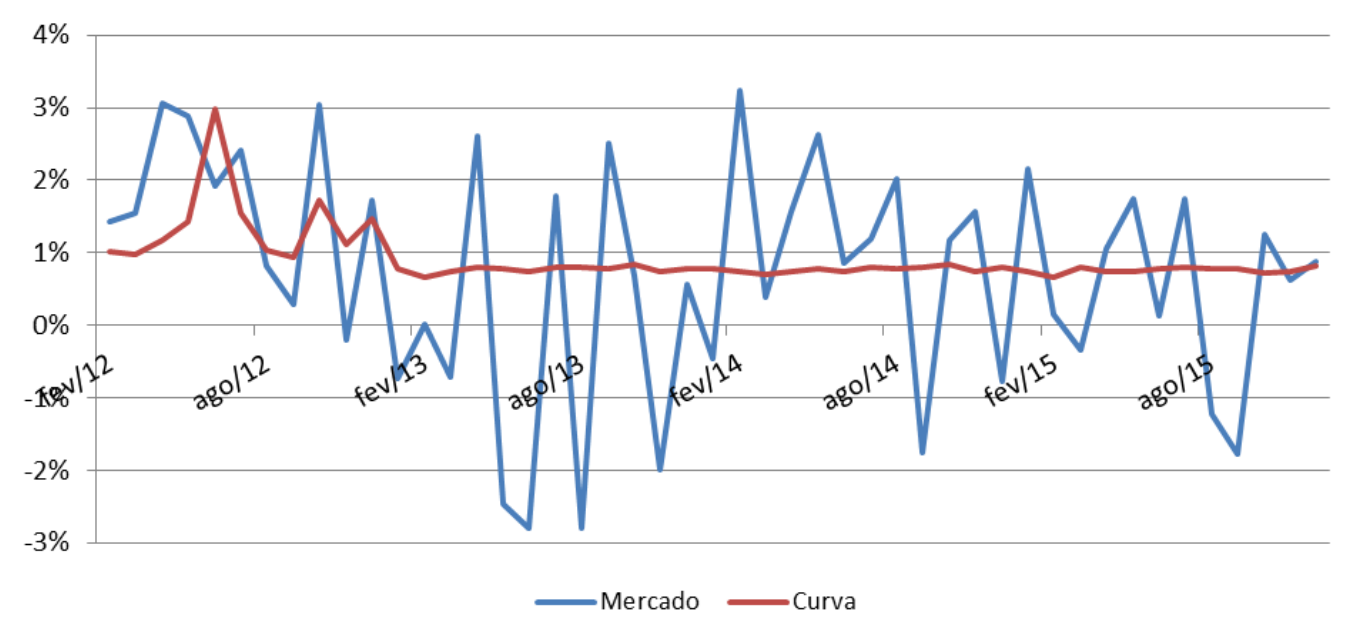

Fonte: Autor, 2016.

$\mathrm{RMSE}=1,51$ ponto percentual 


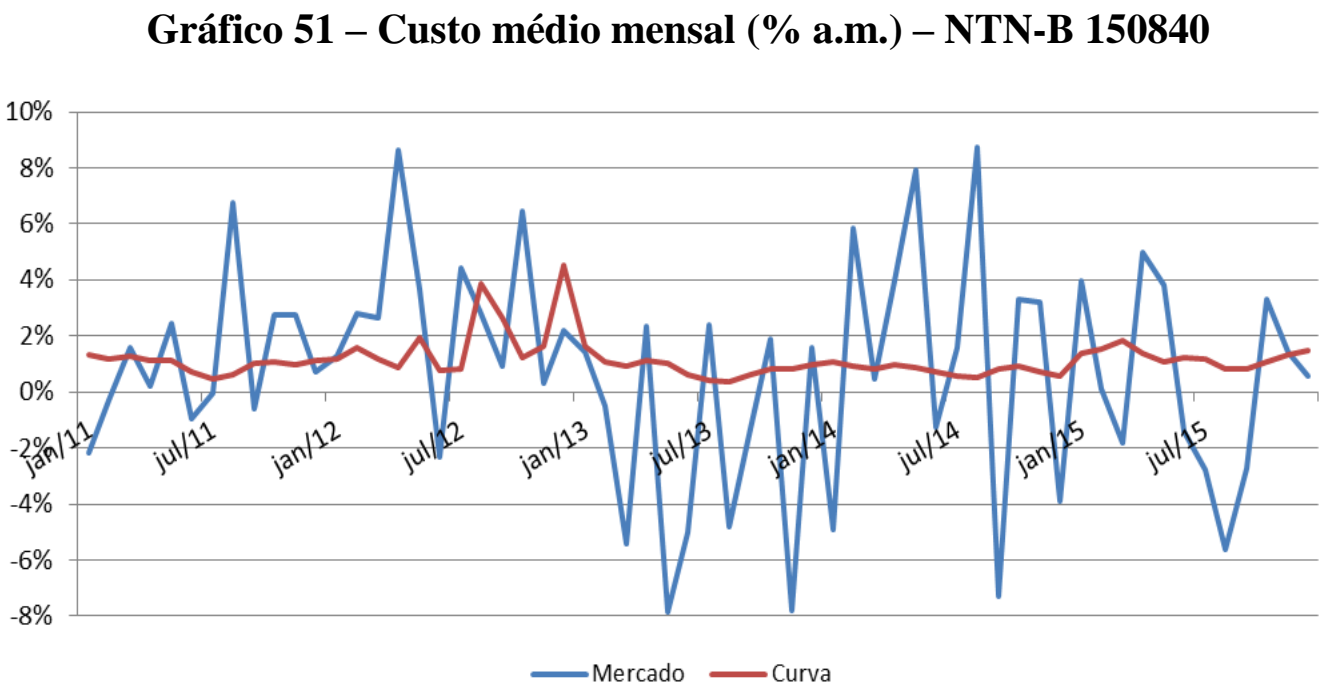

Fonte: Autor, 2016.

\section{$\mathrm{RMSE}=3,82$ pontos percentuais}

A trajetória do custo médio da NTN-B 150840 entre dezembro de 2010 e dezembro de 2015 mostra um comportamento similar ao apresentado nos gráficos do custo médio da LTN 010116 e NTN-F 010118, porém com maior volatilidade do custo apurado pelos valores de mercado, o que ficou explicitado pelo resultado expressivo do RMSE, de 3,82 pontos percentuais.

Apesar da similaridade, pode-se perceber que o custo médio apurado na curva da NTNB 150840 também apresenta maior volatilidade em relação a LTN 010116 e a NTN-F 010118, em virtude da indexação desse título ao IPCA. As flutuações intensas no segundo semestre de 2012 são o reflexo das novas emissões realizadas no período que elevaram o preço na curva, o que compatível com o que foi observado no Gráfico 16, que mostra a trajetória de preços desse título. 
Gráfico 52 - Custo médio mensal (\% a.m.) - LFT 010318

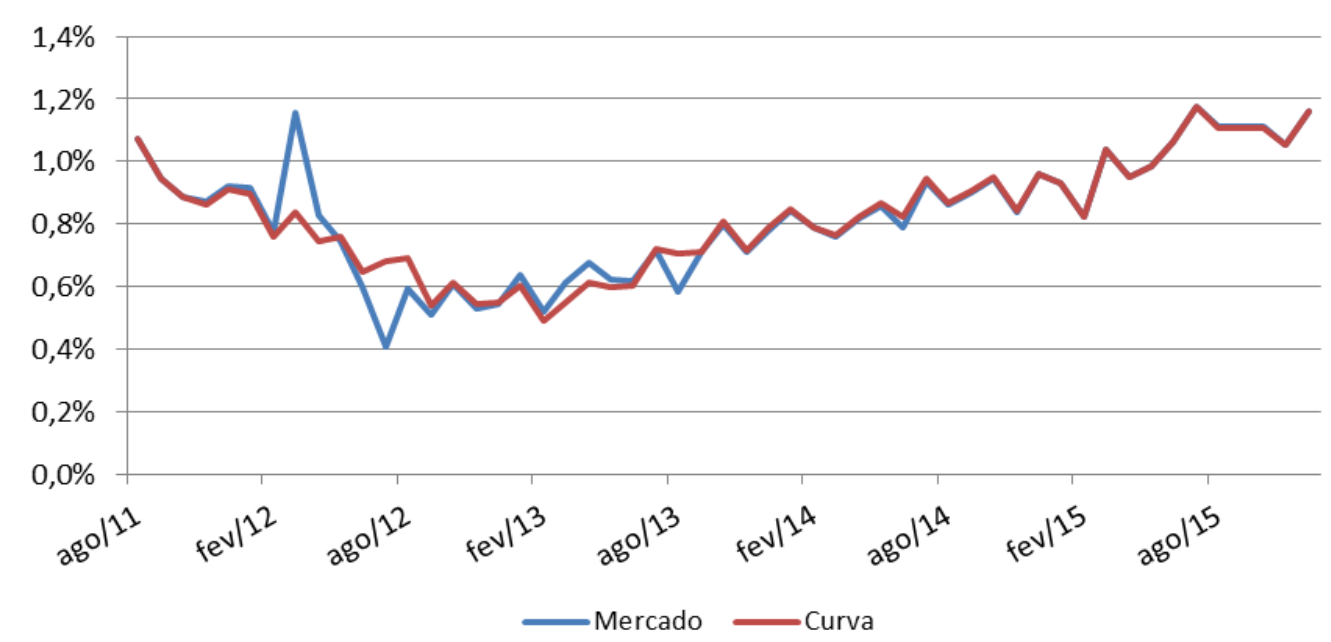

Fonte: Autor, 2016.

\section{RMSE $=0,07$ ponto percentual}

O gráfico do custo mensal médio da LFT 010318, assim como o RMSE de 0,07 ponto percentual, mostram a aderência entre a variação dos preços pelas duas metodologias, o que converge com os resultados das séries de preços apresentados anteriormente. 
Tabela 8 - Resultados do custo médio mensal dos títulos da DPMFe

\begin{tabular}{|c|c|}
\hline Título & $\begin{array}{c}\text { RMSE custo } \\
\text { (pontos percentuais) }\end{array}$ \\
\hline Euro 2011 & - \\
\hline Euro 2012 & $\mathbf{0 , 7 8}$ \\
\hline Euro 2015 & 0,64 \\
\hline Eurolira 2017 & 1,03 \\
\hline Euro 2021 & 3,63 \\
\hline Euro & $\mathbf{1 , 8 8}$ \\
\hline Global 2011 & 0,83 \\
\hline Global 2012 & 2,63 \\
\hline Global 2013 & 0,84 \\
\hline Global 2014 & 0,79 \\
\hline Global 2015 & 0,80 \\
\hline Global 2017 & 0,99 \\
\hline Global 2019 & 1,71 \\
\hline Global 2019-A & 1,49 \\
\hline Global 2020 & 1,87 \\
\hline Global 2021 & 2,04 \\
\hline Global 2023 & 2,80 \\
\hline Global 2024 & 2,66 \\
\hline Global 2024-B & 2,65 \\
\hline Global 2025 & 2,68 \\
\hline Global 2025 A & 2,78 \\
\hline Global 2027 & 2,85 \\
\hline Global 2030 & 3,20 \\
\hline Global 2034 & 3,76 \\
\hline Global 2037 & 2,54 \\
\hline Global 2040 & 1,28 \\
\hline Global 2041 & 4,28 \\
\hline Global 2045 & 4,67 \\
\hline Global A-Bond 2018 & $\mathbf{0 , 5 8}$ \\
\hline Global & 2,29 \\
\hline Global BRL 2016 & 1,80 \\
\hline Global BRL 2022 & 3,88 \\
\hline Global BRL 2024 & 2,97 \\
\hline Global BRL 2028 & 3,38 \\
\hline Global BRL & 3,49 \\
\hline
\end{tabular}

Fonte: Autor, 2016.

Conforme observado na DPMFi, o RMSE do custo médio dos títulos da DPMFe refletiu as variações nos preços de mercado e pela curva dessas siglas. O custo médio dos bônus Global BRL apresentou valores superiores aos apurados no Euro e Global no período estudado em função da maior volatilidade das taxas de juros do título referenciado na moeda nacional, que incorporam o risco cambial assumido pelo credor. 
Gráfico 53 - Custo médio mensal (\% a.m.) - Euro 2021

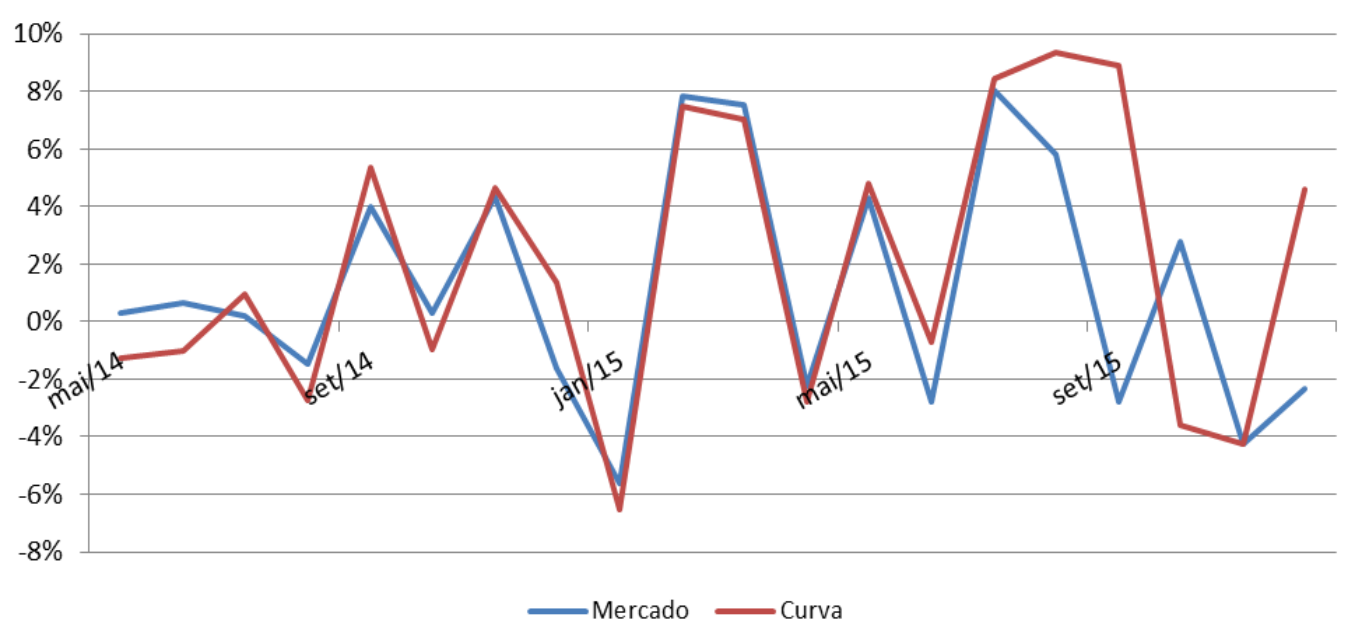

Fonte: Autor, 2016.

\section{$\mathrm{RMSE}=3,63$ pontos percentuais}

O custo médio dos bônus denominados em moedas estrangeiras, Euro e Global, permitem observar a alta volatilidade do custo tanto na precificação pelos valores de mercado quanto na precificação pela curva, o que é explicado pela indexação desses títulos às moedas euro e dólar, respectivamente, que afetam igualmente os preços de mercado e na curva.

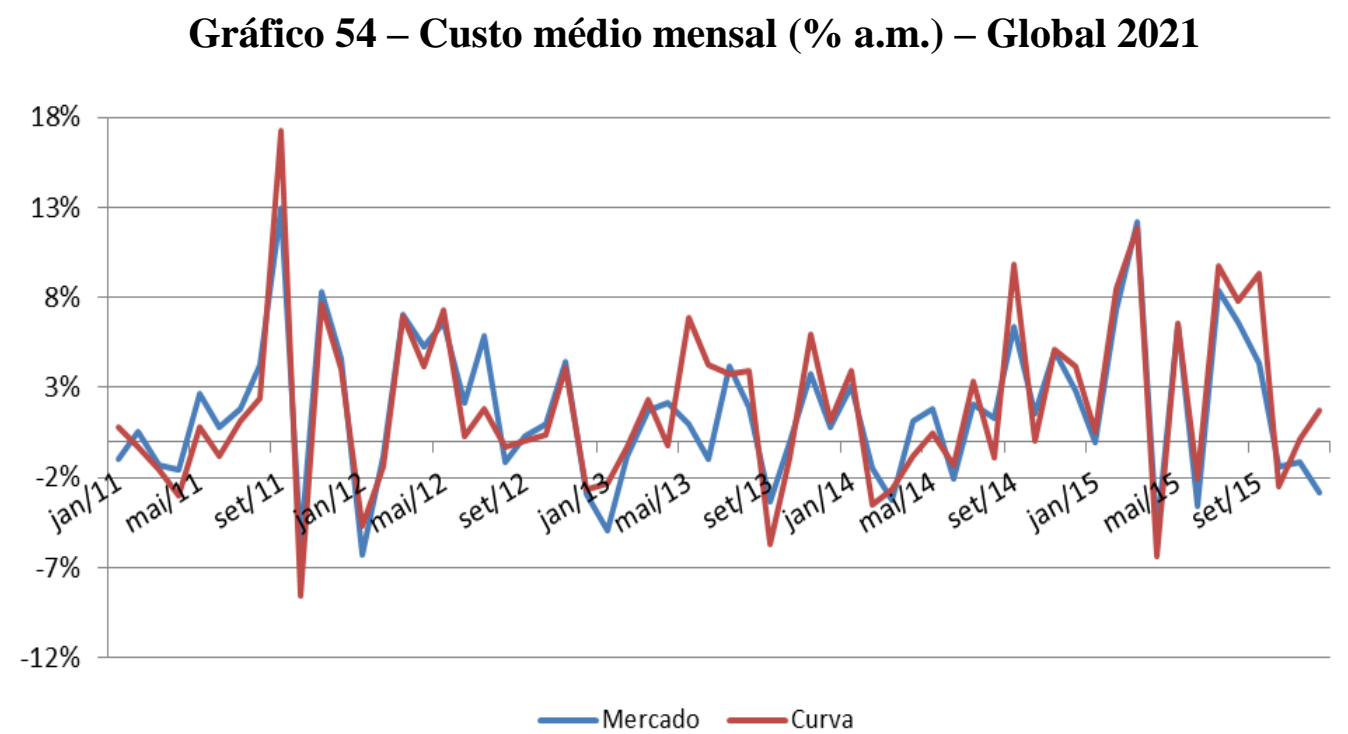

Fonte: Autor, 2016.

\section{RMSE $=2,04$ pontos percentuais}


Gráfico 55 - Custo médio mensal (\% a.m.) - Global BRL 2028

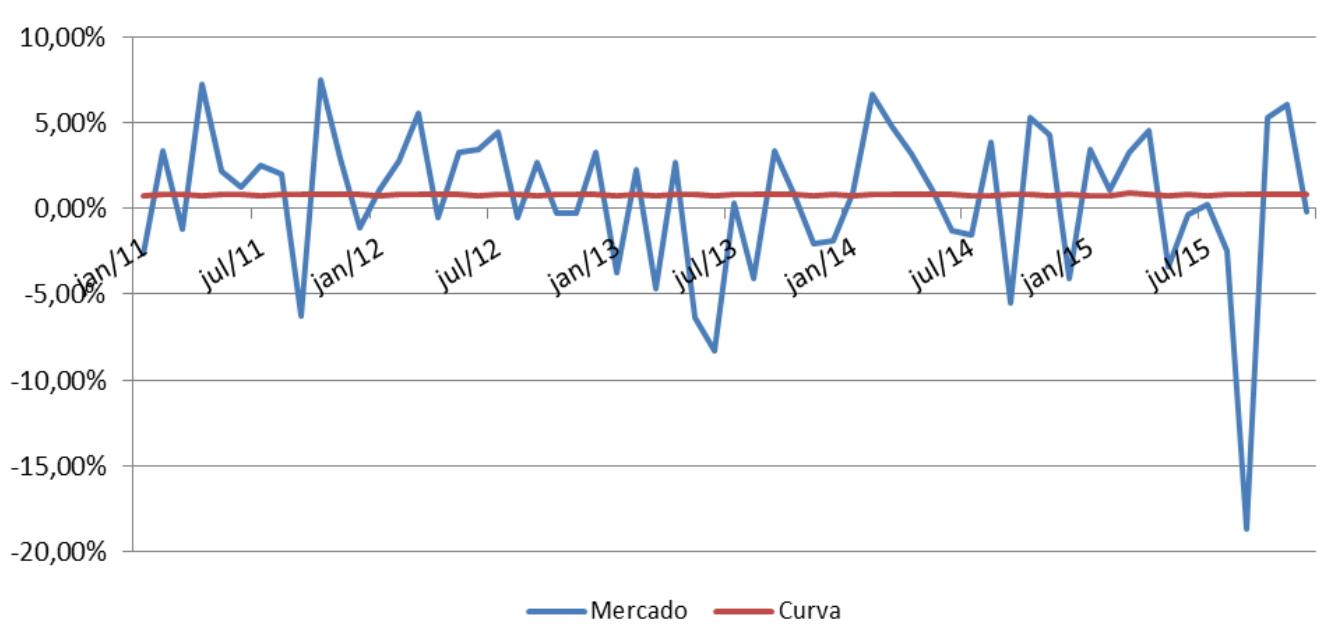

Fonte: Autor, 2016.

\section{$\mathrm{RMSE}=3,38$ pontos percentuais}

O gráfico de custo médio do Global BRL 2028 mostra a estabilidade da taxa de variação dos preços apurados na curva, em contraste com a volatilidade do custo médio calculado a valor de mercado, que refletem a expressiva flutuação nos preços apurados por essa metodologia. Pode-se perceber a similaridade entre o comportamento do custo médio na curva do Global BRL 2028 com o observado na LTN e na NTN-F, que têm taxas prefixadas. 


\section{DISCUSSÃO}

Os resultados apurados no capítulo anterior mostram a existência de diferentes desvios dos valores apurados na curva em relação aos valores de mercado, de acordo com as características dos títulos e o comportamento das taxas de juros no período analisado.

Com base nos resultados do RMSE do preço na curva em relação ao preço de mercado, foi possível dimensionar o distanciamento entre os preços apurados pelas duas diferentes metodologias no período de dezembro de 2010 a dezembro de 2015.

Em função da indexação à taxa Selic, que possui repactuação diária, as LFT são negociadas por valores muito próximos de seu VNA, ou, em outras palavras, as taxas de mercado são muito próximas de zero. Isso justifica a proximidade entre os preços calculados pelas diferentes metodologias, explicitada pelo RMSE de $0,05 \%$.

Quanto aos demais títulos da DPF, pode-se afirmar que a precificação pela curva, adotada no cálculo e divulgação do estoque da DPF pela Secretaria do Tesouro Nacional, não pode ser considerada uma boa aproximação do valor de mercado dos títulos. Embora o preço na curva seja marginalmente afetado pelas variações das taxas de mercado à medida que novas emissões são realizadas, aproximando-o do preço de mercado, foram observados valores de RMSE expressivos. Dentre eles, destacam-se os resultados obtidos na NTN-F $(5,16 \%)$, na NTN-B (7,99\%), no Euro (11,59\%), no Global (20,09\%) e no Global BRL $(10,88 \%)$.

Já o RMSE da dívida pública federal total foi de 4,33\%, o que pode ser explicado pelo peso representativo das LFT e das LTN na DPF, que registraram RMSE de 0,05\% e 2,09\%, respectivamente.

Em relação à análise individual dos títulos, os maiores RMSE foram verificados na NTN-B 150545 (17,46\%) e NTN-B 150535 (15,29\%), entre os títulos da DPMFi, e nos bônus Global 2030 (46,73\%), Global 2024 (44,77\%), Global 2024-B (43,71\%) e Global 2027 $(39,11 \%)$ na DPMFe, durante o período investigado.

No que se refere aos fatores que explicam os desvios entre os valores apurados pelas duas diferentes metodologias, a análise de regressão múltipla foi realizada tendo como variável dependente o RMSE do preço na curva em relação ao preço de mercado, enquanto o desvio padrão das taxas no período analisado em relação à primeira taxa de emissão dos títulos, a duration dos títulos no início da análise e as características de indexação dos títulos foram utilizadas como variáveis explicativas.

$\mathrm{O}$ resultado do teste $\mathrm{F}$ de significância global do modelo, de aproximadamente zero, inferior ao nível de significância estabelecido $(\alpha=0,05)$, permite concluir que o modelo é válido 
para explicar o RMSE. Já os valores $p$ das variáveis explicativas, expostos na Tabela 4, mostram que há evidência estatística de que tais variáveis estão fortemente relacionadas aos resultados encontrados de RMSE.

$\mathrm{O}$ valor do $\mathrm{R}^{2}$ Ajustado, por sua vez, revelou que essas três variáveis em conjunto explicam aproximadamente $72 \%$ da variabilidade do RMSE do preço na curva em relação aos preços de mercado dos títulos públicos, o que representa um alto poder explicativo do modelo.

Os resultados obtidos por meio da pesquisa survey permitiram delinear um perfil dos escritórios de administração de dívida dos diversos países quanto à metodologia de precificação dos títulos adotada na apuração do estoque da dívida pública. Apesar da recomendação dos organismos internacionais pela marcação a mercado como metodologia de apuração do estoque, apenas $16 \%$ dos países declarou seguir essa recomendação, o que revela um distanciamento entre as práticas adotadas pelos países e aquelas recomendadas pelos organismos internacionais. A segmentação dos países pelo nível de desenvolvimento econômico possibilitou verificar que esse percentual foi superior no grupo de países classificados como economias avançadas, chegando a 27\%, o que mostra uma maior adequação desta metodologia às características do mercado de títulos públicos desses países.

Por outro lado, $50 \%$ dos países informou que realiza a apuração do valor de mercado da dívida pública, ainda que esta não seja a metodologia oficial de apuração. Isso significa que a metade dos países respondentes utiliza a marcação a mercado da dívida pública como informação relevante para a administração da DPF. Dentre as respostas espontâneas fornecidas quanto à finalidade da apuração do valor de mercado da dívida pública, destacam-se a utilidade dessa informação para as operações de gerenciamento de passivos, como emissões e resgates antecipados, além da análise de risco do endividamento e da formação de composição ótima de passivos.

No que tange à escolha de uma metodologia de cálculo para um determinado indicador, Silva e Medeiros (2009) argumentam que não se deve considerar uma metodologia certa ou errada sem antes avaliar os prós e os contras de sua utilização, bem como suas implicações.

Um dos aspectos que devem ser levados em consideração na análise sobre a metodologia adequada para o cálculo de um indicador é a compatibilidade entre a estatística produzida e aquilo que se pretende medir (BONOMO et al., 2003). Especificamente a respeito dos diferentes métodos de precificação dos títulos na apuração do estoque, cada um deles se mostra mais adequado para cada tipo de análise que se deseja fazer. Silva e Medeiros (2009) acrescentam que a escolha da metodologia de apuração do estoque por parte do escritório de administração de dívida pública de um determinado país deve refletir suas percepções de risco 
em relação a ela, bem como as dificuldades na geração de estatísticas com qualidade sob um ou outro critério. Neste sentido, podem ser apontadas vantagens e desvantagens da apuração do estoque da dívida pela marcação a mercado, as quais serão abordadas nas páginas seguintes.

Esses aspectos reforçam a ideia de complementariedade entre as informações geradas pelos diferentes métodos de apuração. A correta interpretação dos resultados obtidos a partir de diferentes indicadores forma um conjunto informativo mais abrangente e aprofundado, dando suporte à tomada de decisão por parte dos gestores de dívida pública. Essa afirmativa vai ao encontro de uma das conclusões do trabalho de Dembiermont et al. (2015), o qual mostra que as diferentes metodologias de mensuração de dívida geram informações que permitem análises distintas e complementares. Nesse mesmo sentido, Dippelsman et al. (2012) e Irwin (2015) recomendam a produção de diferentes medidas de dívida por parte dos escritórios de administração de dívida, com o objetivo de se montar um quadro diversificado de informações.

Um importante argumento que justifica a recomendação do FMI pelo apreçamento dos títulos por seus valores de mercado é o fato dessa metodologia apresentar o valor mais próximo daquele pelo qual o título seria transacionado numa eventual negociação em mercado. Desta forma, a apuração do estoque pela marcação a mercado, que é impactada pelas flutuações das taxas de rentabilidade dos títulos, reflete a realidade do mercado no momento da apuração. Conforme argumenta Medeiros (2003), a avaliação dos passivos do governo deveria ser realizada pelo valor que seria exigido pelo mercado caso o governo decidisse antecipar o pagamento daquela dívida.

Em função dessa característica, a marcação a mercado evita grandes distorções no registro de eventuais transações em mercado ocorridas antes do vencimento dos títulos, como operações de recompra antecipada, trocas, leilões de compra de títulos etc. Tais divergências ocorrem porque o valor pelo qual o título está registrado, na curva, difere do valor pelo qual o título foi resgatado, podendo, em certo momentos, ser consideravelmente inferior ou superior ao valor de mercado, como apontou o estudo empírico.

$\mathrm{O}$ fato de ter um posicionamento atuante no mercado, seja por novas emissões ou por operações de resgates antecipados, aponta para a necessidade de se realizar o acompanhamento constante do valor de mercado dos títulos. Ademais, a avaliação do estoque por essa metodologia permite a apuração das variações dos preços dos títulos em função das flutuações das taxas de mercado, refletindo de maneira mais fiel o risco de mercado da carteira da dívida pública.

No contexto brasileiro, estas operações são realizadas de forma regular na gestão da DPMFe por meio do programa de buyback da Dívida Externa. Trata-se de um instrumento de 
gerenciamento do passivo externo que permite ao Tesouro Nacional, por meio de atuações pontuais e oportunas, aprimorar a curva de juros da dívida externa (SECRETARIA DO TESOURO NACIONAL, 2015d). Nessa situação, os títulos recomprados pela STN são transacionados sob as condições de mercado, enquanto suas posições de estoque estão apuradas pelos preços na curva, gerando divergência entre esses valores.

Outro exemplo de pagamentos antecipados realizados pela Secretaria do Tesouro Nacional, com periodicidade diária, se refere à carteira de títulos vendidos através do programa Tesouro Direto. Esse programa, criado em 2002, possibilita a venda de títulos públicos a pessoas físicas por meio da internet (SECRETARIA DO TESOURO NACIONAL, 2015d). Apesar de atualmente a carteira de títulos emitidos por este programa representar apenas uma fatia de cerca de $1 \%$ do estoque total da DPF, o programa merece destaque por uma particularidade em relação aos títulos emitidos pelos leilões tradicionais: os títulos comprados podem ser resgatados antecipadamente pelos credores a qualquer momento entre a data da compra e o vencimento do papel. Essa peculiaridade gera uma situação em que o Tesouro Nacional se depara com fluxos de pagamentos diários fora de sua programação regular, por seus valores de mercado, que podem ser significativamente divergentes do valor pelo qual o título está registrado no estoque, como pôde ser constatado no estudo empírico.

Um conceito bastante relevante na gestão de títulos públicos e que dá sustentação à marcação a mercado é o de fungibilidade, segundo o qual dois títulos iguais, em um mercado líquido, devem ter necessariamente o mesmo valor, independentemente da data da compra ou da sua taxa de emissão. Bonomo et al. (2003) apresentam um exemplo em que o Tesouro Nacional realiza duas emissões de um mesmo título com taxas de rentabilidade diferentes. Numa situação como essa, a precificação pela curva apresenta diferentes preços para o mesmo título no momento da apuração do estoque. Por outro lado, na marcação a mercado, cada um dos títulos tem apenas um preço, dado pelo desconto dos fluxos futuros do título pela sua taxa de mercado na data de apuração do estoque.

Outro importante aspecto que justifica um acompanhamento frequente do valor de mercado da carteira de títulos é a avaliação do risco pelo lado da demanda, o qual é definido como o risco de mudanças repentinas na demanda por títulos do governo. Embora possa ocorrer por diversos motivos, o fator mais comum de mudanças abruptas de curto prazo na demanda por ativos governamentais é a flutuação das taxas de juros (DEMBIERMONT et al., 2015; SILVA; CABRAL; BAGHDASSARIAN, 2009).

Crescentemente, devido a regulações prudenciais mais estritas ou a políticas internas, os investidores têm feito uso de medidas de exposição às taxas de juros para monitorar seu risco 
de perdas. No mercado de renda fixa, um dos indicadores de risco mais frequentemente utilizados é o Value-at-Risk (VaR), que mostra a maior perda esperada de um ativo ou carteira de ativos, para um determinado período, dada uma probabilidade de ocorrência (SILVA; CABRAL; BAGHDASSARIAN, 2009).

Destaca-se que o conceito de VaR está intimamente ligado à marcação a mercado, por mensurar a sensibilidade do valor de mercado da carteira às variações dos indicadores econômicos num horizonte de tempo determinado (BONOMO et al., 2003).

Uma parte significativa dos demandantes de títulos públicos, especialmente no Brasil, está sujeita à observância de limites quanto à exposição ao risco de taxa de juros. Tal fato traz restrições ao gestor da dívida pública para a transferência de risco de taxa de juros ao mercado. Durante momentos de alta volatilidade, o VaR pode atingir níveis elevados e levar a operações de stop-loss por parte dos investidores. Tais mudanças na demanda podem gerar impactos expressivos na implantação de uma determinada estratégia de endividamento. Destarte, o monitoramento desse risco constitui uma importante atribuição do gestor da dívida pública (SILVA; CABRAL; BAGHDASSARIAN, 2009).

Do ponto de vista operacional, pode-se apontar a apuração do estoque pela marcação a mercado como metodologia que apresenta um menor nível de complexidade em relação à apuração pelo preço na curva. Essa afirmação leva em consideração que o cálculo do estoque pelos preços na curva tem como condição necessária a realização da precificação de cada uma das emissões do título, desde a primeira operação, por suas respectivas taxas de rentabilidade para a data de referência do estoque.

Outra questão favorável à apuração do valor de mercado da dívida pública se refere à legitimidade das estatísticas produzidas. Como apontado por Dembiermont et al. (2015) e Dippelsman et al. (2012), a padronização das informações coletadas pelos organismos internacionais permite a comparabilidade dos resultados obtidos entre os diversos países. Desta forma, seguir a recomendação dos órgãos internacionais na elaboração de relatórios oficiais posicionaria o país no grupo de escritórios de administração de dívida pública que adota as melhores práticas de gestão.

Em contrapartida às questões acima discutidas, um dos principais argumentos que pode ser apontado como desfavorável à adoção da marcação a mercado como método oficial de apuração do estoque da dívida pública é o efeito antagônico que as flutuações das taxas de juros de mercado provocam no estoque da dívida pública. Conforme verificado no estudo empírico, caso haja um aumento nas taxas de juros de mercado em consequência de uma piora nas condições de mercado para o emissor da dívida, temos uma redução do preço do título marcado 
a mercado e a redução do estoque financeiro da dívida. Isso poderia ser percebido como um sinal positivo, quando, na verdade, a situação é exatamente oposta. Ou, de maneira análoga, a melhora na percepção dos investidores quanto ao risco dos títulos do governo acarretaria uma redução nas taxas de juros, e, como consequência, provocaria um aumento do estoque da dívida. Essa questão foi explorada por Freitas (1999) e Medeiros (2003).

Entretanto, os resultados dos indicadores da dívida pública apontam uma compensação a esse efeito. Como expõe Medeiros (2003), após uma redução do valor do estoque financeiro em virtude de um aumento das taxas de mercado, ter-se-ia, após esse momento, um aumento do seu custo médio, uma vez que os preços passariam a evoluir ao longo do tempo a taxas superiores. Essa afirmação pode ser mais bem compreendida utilizando uma LTN como exemplo. No caso de um aumento da taxa de mercado após uma determinada emissão, o preço de mercado desse título ficará menor que o preço na curva. Considerando-se que o título terá o valor de R \$ 1.000 no vencimento, qualquer que seja o método de precificação, fica claro que o preço de mercado sofrerá um aumento maior que o preço na curva no mesmo período, o que implica um maior custo médio.

Esse mesmo raciocínio se aplica a duration. Conforme apontado no trabalho empírico, se por um lado tem-se uma redução do valor de mercado do estoque da dívida pública em função de um aumento das taxas de mercado, por outro é possível verificar a redução também da sua duration. Conforme explicado no capítulo anterior, as flutuações das taxas de mercado provocam variações nos preços dos títulos, sendo os vencimentos mais longos mais sensíveis a tais flutuações. Neste sentido, numa situação de aumento da taxa de desconto, temos a redução do resultado desse indicador.

Essa constatação permite concluir que, apesar de a marcação a mercado sinalizar um aparente contrassenso quando ocorre uma redução do valor da dívida como consequência do aumento das taxas de juros, pode-se observar nessa situação, como uma compensação a esse efeito, uma piora da qualidade do endividamento apurada por seus indicadores de custo e risco. Tal argumentação fortalece a importância desses indicadores como parâmetros relevantes quanto à qualidade do endividamento público. Ademais, mostra que a análise de um conjunto de indicadores, e não de apenas um isoladamente, permite uma tomada de decisão mais bem informada quanto às estratégias de endividamento público.

Bonomo et al. (2003) acrescentam que esse efeito contraintuitivo nos movimentos de estoque e taxa de juros acontece porque somente os passivos estão sendo analisados. Caso os ativos e as receitas fiscais sejam incluídas no balanço, os sinais corretos são percebidos. No caso de um aumento das taxas de mercado, por exemplo, a redução do estoque da dívida seria 
acompanhada por um decréscimo também no preço dos ativos em função do aumento da taxa de desconto.

As escolhas feitas quanto aos instrumentos de financiamento utilizados devem levar em consideração os diferentes níveis de risco específico, que dependem não só das características dos títulos emitidos, mas também da natureza dos ativos e receitas do emissor, uma vez que são estes que garantirão o pagamento dos títulos emitidos. Faz todo o sentido que o governo gerencie seus passivos levando em conta as características de seus ativos (COLBANO; LEISTER, 2015; SILVA; CABRAL; BAGHDASSARIAN, 2009). O gerenciamento combinado de ativos e passivos (Asset and Liability Management - ALM) se caracteriza pela estratégia de emissão de dívida com riscos semelhantes aos das receitas governamentais, o que permitiria reduzir a volatilidade da dívida líquida do governo (COSTA, 2009). Neste contexto, uma apuração dos preços por seus valores de mercado no gerenciamento de ativos e passivos produz uma informação mais precisa quanto à situação financeira do governo.

O fato de captar as flutuações das taxas de rentabilidade dos títulos confere à série de preços de mercado uma trajetória mais instável, conforme observado no estudo empírico realizado. Neste sentido, a marcação a mercado adicionaria volatilidade à trajetória do estoque, o que poderia, inclusive, mascarar outros fatores que geram variações do estoque. Dippelsman et al. (2015) apresentam o exemplo da dívida grega entre 2009 e 2010 que ilustra esse tipo de situação. Nesse período, a dívida pública apurada pelos valores nominais se elevou pela realização de empréstimos adicionais no período, enquanto a dívida a valores de mercado apresentou redução em função da elevação das taxas de mercado. Segundo Bonomo et al. (2003), a utilização do conceito de marcação a mercado gera indicadores que tendem a apresentar maior grau de volatilidade, dificultando a tarefa de comunicar ao público o comportamento da dívida pública.

Outro ponto que deve ser mencionado acerca da escolha da metodologia de apuração do estoque é que essa definição não se reflete em alteração no fluxo regular de pagamentos. Isso significa que, independentemente do método escolhido para a precificação dos títulos na apuração do estoque da dívida pública, os pagamentos de juros ou de principal assumem valores idênticos nas suas datas de vencimento. O trabalho empírico mostrou que a diferença entre os valores apurados pelas diferentes metodologias diminui à medida que se aproxima a data de vencimento, até se tornarem iguais nesta data. Essa é uma justificativa usada por muitos países para utilizar a precificação dos títulos apenas por seus valores nominais, pois a principal variável de interesse seria o valor futuro, e não o valor presente dos pagamentos da dívida. 
Entretanto, conforme argumentado anteriormente, caso a gestão da dívida pública tenha uma atuação ativa no mercado secundário e haja operações de resgates antecipados, como nos exemplos citados anteriormente, essas negociações ocorrem por seus preços de mercado. Nesse contexto, a marcação a mercado parece fazer mais sentido para a administração de carteiras de dívida que sejam transacionadas frequentemente, o que tornaria fundamental a apuração do preço dos títulos pelos valores mais próximos daqueles que seriam praticados no caso de uma negociação.

Deve-se mencionar ainda que, apesar de representar a melhor aproximação do valor real do título no caso de uma negociação, o estoque da dívida pública apurado pelo conceito de marcação a mercado reflete uma posição estática dos preços dos títulos, mostrando o valor da primeira unidade de cada título. Conforme argumentado por Medeiros (2003), à medida que se realizam transações do título em mercado, seu preço se altera, tanto mais quanto menor a sua liquidez e maior o volume total a venda.

O estudo empírico, que teve como recorte temporal o intervalo entre 31 de dezembro de 2010 e 31 de dezembro de 2015, período que apresentou forte volatilidade das taxas de rentabilidade dos títulos, possibilitou verificar o impacto das diferentes metodologias de apuração do estoque nos indicadores do endividamento.

No que se refere aos indicadores de maturidade da dívida, apesar de a precificação pela curva não refletir integralmente as variações das taxas, essa metodologia possibilita o cálculo dos indicadores respeitando o conceito de valor presente adotado na precificação dos títulos. Já os resultados do ATM se mostraram bastante superiores aos de prazo médio e duration. Diferenças similares foram apontadas por Leister (2012). Conforme descrito no referencial teórico, isto ocorre em função de este indicador não se fundamentar no conceito de valor presente, levando em conta apenas o valor de face dos títulos. Ademais, não considera os pagamentos de cupom de juros e, neste sentido, não representa um bom indicador de risco de refinanciamento para dívida pública.

Entretanto, o cálculo do ATM se revela fundamental por se tratar do indicador de maturidade mais disseminado entre os escritórios de administração de dívida, representando uma referência no que diz respeito a comparativos internacionais (LEISTER, 2012). Isso reforça a importância de se realizar diferentes mensurações para o indicador de maturidade da dívida a fim de prover um conjunto diversificado de informações ao gestor da dívida pública.

Ainda a respeito das questões acima apontadas, Bonomo et al. (2003) e Silva, Cabral e Baghdassarian (2009) explicam que o uso da duration como meta poderia gerar incentivos equivocados e levar o governo a tomar decisões paradoxais. 
Em uma situação de aumento de taxa de juros e, consequentemente, redução da duration, o gestor de dívida pública poderia ser levado a aumentar a emissão de títulos de longo prazo para contornar essa redução e atingir a meta estabelecida para este indicador. Entretanto, nesse caso, ele emitiria títulos mais longos justamente no momento em que as taxas de juros estão mais altas (SILVA; CABRAL; BAGHDASSARIAN, 2009).

De maneira similar, no que se refere ao estoque financeiro da dívida pública federal, é possível imaginar uma situação em que o governo poderia usar uma estratégia pouco ortodoxa de aumento da taxa de juros com o objetivo de reduzir o estoque da dívida pública e atingir a meta estabelecida no Plano Anual de Financiamento deste indicador. Nas duas situações, o governo sofreria, como consequência destas ações, um aumento no custo de financiamento da dívida pública no futuro.

No que tange ao custo médio da DPF, as diferenças verificadas entre os resultados apurados pelas duas metodologias se revelaram expressivas. O trabalho empírico mostrou que este indicador, apurado a partir do valor de mercado dos títulos, apresentou alta volatilidade em virtude de refletir as flutuações das taxas de mercado. Já a apuração do custo médio tendo como referência os valores na curva, metodologia atualmente utilizada pela Secretaria do Tesouro Nacional, mostrou que este indicador é afetado apenas pelas novas emissões e pela variação de seus indexadores, o que resultou em um indicador mais estável ao longo do tempo.

Neste sentido, para os países que gerenciam ativamente seus portfólios de dívida, o custo médio deve ser medido em termos de mudanças no valor de mercado dos títulos que compõem a sua carteira, expressando suas valorizações ou desvalorizações ao longo do tempo, em linha com a precificação dos títulos pela marcação a mercado (BANCO MUNDIAL; FUNDO MONETÁRIO INTERNACIONAL, 2014). Como ponto negativo desta mensuração, pode-se apontar a difícil comunicação e interpretação de seus resultados em função da alta volatilidade deste indicador. 


\section{CONCLUSÕES E CONSIDERAÇÕES FINAIS}

O estoque financeiro da dívida pública pode ser apontado como um dos principais indicadores para as finanças públicas de um país. A gestão da dívida pública, entretanto, precisa contar com um conjunto abrangente de indicadores que retratem a qualidade do endividamento e constituam os parâmetros para a implantação e monitoramento de estratégias de financiamento da DPF. Nesse contexto, ressalta-se a importância da definição do método de precificação dos títulos na apuração do estoque da DPF em função do impacto significativo provocado na mensuração de tais indicadores.

Os resultados da pesquisa survey mostraram que apenas $16 \%$ dos países que responderam à pesquisa adotam a marcação a mercado como estatística oficial de apuração do estoque da dívida pública, revelando a existência de uma lacuna entre as práticas recomendadas pelos organismos internacionais e aquelas adotadas pelos países, no que se refere à metodologia de precificação dos títulos na avaliação do estoque da dívida pública.

Entre os países classificados como economias avançadas, esse resultado foi de $27 \%$. No grupo de países classificados como economias emergentes, esse valor foi de 13\%, enquanto nos países de baixa renda esse percentual foi de apenas $12 \%$. Esse resultado mostra que, dentre os países que responderam ao questionário, o grupo classificado como economias avançadas possui maior participação relativa de países que produzem suas estatísticas oficiais pelo conceito de marcação a mercado. Ademais, permite concluir que essa metodologia se mostra mais adequada às características do mercado de dívida pública desses países.

Quanto à comparação entre as metodologias de apuração do estoque da DPF, os resultados do estudo empírico apontaram diferenças expressivas entre os valores de mercado e os valores na curva dos títulos públicos entre dezembro de 2010 e dezembro de 2015. Nesse sentido, a precificação pela curva, atualmente adotada pelo Banco Central do Brasil e pela Secretaria do Tesouro Nacional, embora seja afetada marginalmente pelas taxas de mercado à medida que novas emissões sejam realizadas, não pode ser considerada uma boa aproximação do valor de mercado dos títulos.

Os resultados obtidos pela análise de regressão múltipla revelaram que as diferenças verificadas entre os preços apurados a valor de mercado e pela curva variam em função da volatilidade das taxas de rentabilidade ocorridas entre a emissão e vencimento dos títulos, da duration dos títulos e das características de indexação dos títulos públicos.

Em contrapartida, os preços na curva apresentam uma trajetória mais previsível em relação aos preços de mercado, gerando valores de estoque mais inteligíveis ao longo do tempo. 
Ademais, essa metodologia possibilita a apuração dos indicadores do endividamento respeitando o conceito de valor presente e a uniformidade metodológica adotada na apuração do estoque.

O preço de mercado dos títulos públicos, por sua vez, pode ser considerado o valor mais próximo daquele pelo qual um determinado título seria transacionado na data de apuração do estoque. Entretanto, embora represente uma informação valiosa para a gestão da dívida pública, explicitada pelas questões abordadas no capítulo anterior, determinados aspectos representam dificuldades à adoção deste método de precificação dos títulos como metodologia oficial de apuração do estoque da dívida pública mobiliária. Dentre eles, destacam-se o efeito contraintuitivo gerado no estoque face às mudanças das taxas de mercado e a dificuldade em comunicar suas variações ao longo do tempo devido à maior flutuação dos valores apurados por esta metodologia.

Nesse contexto, a marcação a mercado como metodologia oficial de apuração do estoque da dívida pública se mostra mais adequada a países que realizem um gerenciamento ativo da carteira de passivos, o que justificaria a apuração do estoque pela posição mais fiel às condições de mercado. Isso possibilita a demonstração das valorizações ou desvalorizações da carteira decorrentes das flutuações das taxas de juros, e, consequentemente, permite uma análise mais acurada quanto ao risco de mercado do endividamento público.

Ademais, conforme explorado no capítulo anterior, uma gestão integrada de ativos e passivos - ALM, bem como a divulgação de balanços compreendendo esses dois lados por seus valores de mercado, geraria informações mais precisas sobre a situação financeira do governo, em contrapartida à abordagem contábil tradicionalmente utilizada.

Apesar da importância do cálculo e do monitoramento do estoque marcado a mercado para o gerenciamento da DPF, representando um avanço no que tange à qualidade das estatísticas produzidas, uma adoção da marcação a mercado como metodologia oficial da DPF brasileira parece fazer mais sentido num momento em que o Brasil alcance patamares de taxas de mercado dos títulos públicos menores e mais estáveis, similares às condições encontradas em países de economia avançada.

Outro importante aspecto que justificaria a adoção da marcação a mercado da DPF brasileira seria a ampliação da atuação da Secretaria do Tesouro Nacional no mercado secundário de títulos, assumindo uma postura mais ativa no que se refere a operações de gestão da carteira da dívida pública. O mesmo se aplica no caso de um crescimento do programa Tesouro Direto. Em ambas as situações, o aumento do volume de resgates antecipados, por seus valores de mercado, apontaria para a necessidade da apuração de suas posições de estoque pela 
mesma metodologia, espelhando as flutuações nos preços dos títulos públicos. Nesse contexto, o argumento contrário à marcação a mercado, segundo o qual a metodologia de apuração do valor presente dos títulos não seria relevante uma vez que na data de vencimento o título terá o mesmo valor, qualquer que seja a metodologia adotada, estaria invalidada pela ampliação do volume de operações de resgates antecipados.

Quanto aos indicadores da dívida pública, que compõem o perfil do endividamento, a precificação dos títulos da DPF permitiu dimensionar, respeitando-se a uniformidade metodológica entre a apuração do estoque e dos demais indicadores da DPF, o impacto das diferentes metodologias nos resultados dos indicadores de composição, de maturidade e de custo médio da DPF.

Embora o prazo médio não reflita integralmente as flutuações das taxas de mercado, este indicador se mostra adequado como parâmetro de risco de refinanciamento ao considerar os fluxos de juros e respeitar o conceito de valor presente, alinhado à metodologia de precificação na curva. A apuração do ATM, por sua vez, tem importância substancial por se tratar do indicador de maturidade usado como referência em comparativos internacionais.

Já o custo médio dos títulos da DPF apresentou diferenças expressivas quando comparados os resultados obtidos pelas duas diferentes metodologias, refletindo a maior volatilidade dos preços de mercado em relação ao preço na curva.

Nesse sentido, no que se refere à escolha da metodologia oficial de precificação dos títulos na apuração do estoque da dívida pública, não cabe apontar uma ou outra como certa ou errada, uma vez que ambas se mostram conceitualmente coerentes, mas, sim, determinar aquela mais adequada às necessidades e características da dívida pública de cada país.

É possível concluir que as diferentes mensurações de dívida pública fornecem perspectivas distintas e complementares, proporcionando ao gestor de dívida um conjunto informativo mais completo para a tomada de decisão quanto às estratégias de financiamento da dívida pública, levando-se em consideração a missão de reduzir o custo de refinanciamento no longo prazo, mantendo-se níveis prudentes de risco.

O Quadro 6 sintetiza as conclusões da pesquisa para cada um dos objetivos específicos propostos. 


\section{Quadro 6 - Objetivos específicos e conclusões da pesquisa}

\begin{tabular}{|c|c|}
\hline Objetivos específicos & Conclusões \\
\hline $\begin{array}{l}\text { Identificar as diferentes metodologias de cálculo do estoque da dívida } \\
\text { mobiliária adotadas e/ou recomendadas por organismos internacionais, } \\
\text { como o Banco Mundial e o Fundo Monetário Internacional, e pelos } \\
\text { órgãos responsáveis pela administração da dívida pública nos diversos } \\
\text { países. }\end{array}$ & $\begin{array}{l}\text { Apesar da recomendação dos organismos internacionais pela marcação a mercado como } \\
\text { metodologia de precificação dos títulos na apuração do estoque da dívida pública, apenas } \\
16 \% \text { dos países ( } 7 \text { de } 44 \text { ) que responderam à pesquisa survey declararam apurar e divulgar o } \\
\text { estoque com base nesta metodologia. Considerando-se apenas o grupo de países de } \\
\text { economia avançada, essa participação chegou a } 27 \% \text { ( } 3 \text { de } 11 \text { países). Por outro lado, a } \\
\text { metade dos países participantes informou utilizar o valor de mercado dos títulos como } \\
\text { informação relevante para a gestão da dívida pública. }\end{array}$ \\
\hline $\begin{array}{l}\text { Calcular, por meio da precificação dos títulos públicos, o estoque da } \\
\text { dívida pública federal brasileira - DPF utilizando a marcação a mercado } \\
\text { como método de apuração e comparar os resultados obtidos aos valores } \\
\text { divulgados pelo método de precificação pela curva adotado atualmente } \\
\text { pelo Brasil. }\end{array}$ & $\begin{array}{l}\text { Verificou-se a existência de diferentes desvios dos valores apurados na curva em relação } \\
\text { aos valores de mercado, de acordo com as características dos títulos e o comportamento das } \\
\text { taxas de juros no período analisado. Dentre os títulos da DPMFi, as NTN-B apresentaram } \\
\text { maior RMSE (7,99\%), enquanto os títulos Global tiveram o maior RMSE (20,09\%) na DPMFe. } \\
\text { Os resultados expressivos de RMSE no período analisado permitem concluir que o preço na } \\
\text { curva não representa uma boa aproximação do valor de mercado dos títulos. }\end{array}$ \\
\hline $\begin{array}{l}\text { Identificar as variáveis que explicam as diferenças apuradas entre os } \\
\text { preços na curva e os preços de mercado dos títulos públicos. }\end{array}$ & $\begin{array}{l}\text { Os resultados da regressão múltipla mostraram que as variáveis explicativas utilizadas - o } \\
\text { des vio padrão das taxas no período analisado em relação à primeira taxa de emissão dos } \\
\text { títulos, a duration no início da análise e a característica de indexação do título, explicam em } \\
72 \% \text { o comportamento do RMSE do preço na curva em relação aos preços de mercado dos } \\
\text { títulos públicos no período analisado. }\end{array}$ \\
\hline $\begin{array}{l}\text { Mensurar o impacto das diferentes metodologias de apuração do } \\
\text { estoque nos indicadores de custo e risco da dívida pública. }\end{array}$ & $\begin{array}{l}\text { A precificação dos títulos da DPF pelas duas diferentes metodologias permitiu dimensionar, } \\
\text { respeitando-se a uniformidade metodológica entre a apuração do estoque e o cálculo dos } \\
\text { demais indicadores da DPF, o impacto nos resultados de composição, de maturidade e de } \\
\text { custo médio da DPF. Embora o prazo médio não reflita integralmente as flutuações das taxas } \\
\text { de mercado, este indicador se mostra adequado como parâmetro de risco de refinanciamento } \\
\text { ao considerar os fluxos de juros e respeitar o conceito de valor presente. Já a apuração do } \\
\text { ATM tem a finalidade específica de facilitar a comparabilidade internacional. O custo médio, } \\
\text { por sua vez, apresentou diferenças expressivas comparando-se os resultados obtidos pelas } \\
\text { duas diferentes metodologias, uma vez que esse indicador reflete as variações no preço dos } \\
\text { títulos da DPF. }\end{array}$ \\
\hline $\begin{array}{l}\text { Apontar vantagens e desvantagens de uma possível adoção da } \\
\text { marcação a mercado como método de precificação para o estoque da } \\
\text { DPF. }\end{array}$ & $\begin{array}{l}\text { Os preços de mercado dos títulos da DPF representamo valor mais próximo daquele que } \\
\text { seria exigido pelo mercado caso o governo antecipe seu pagamento. Nesse sentido, o } \\
\text { gerenciamento ativo da carteira de dívida pública justificaria a utilização da marcação a } \\
\text { mercado como estatística oficial de apuração do estoque, refletindo suas valorizções e } \\
\text { desvalorizações. Em contrapartida, o fato de sofrer o impacto das flutuações das taxas de } \\
\text { mercado confere aos preços de mercado uma trajetória mais volátil. Ademais, o efeito } \\
\text { contraintuitivo gerado no estoque face às mudanças das taxas de mercado, como apontado } \\
\text { no estudo empírico, dificulta a interpretação dos resultados e a comunicação com o público. } \\
\text { É possível concluir que as diferentes mensurações de dívida pública fornecem perspectivas } \\
\text { distintas e complementares, proporcionando ao gestor de dívida um conjunto de } \\
\text { informações mais completo para a tomada de decisão quanto às estratégias de } \\
\text { financiamento da dívida pública. }\end{array}$ \\
\hline
\end{tabular}

\subsection{LIMITAÇÕES DA PESQUISA}

Uma primeira limitação que pode ser apontada neste estudo se refere à amostragem da pesquisa survey, que se limitou à coleta de respostas espontâneas por parte dos escritórios de administração de dívida. Nesse sentido, não houve a preocupação com a representatividade de cada um dos três grupos de países na amostragem da pesquisa, restringindo a generalização dos resultados.

Ainda sobre a pesquisa survey, o fato de as informações serem prestadas pelos próprios gestores da dívida pública, sem necessariamente passarem por uma comprovação ou conferência, pode ter sugestionado os participantes a declararem a produção de informações mais sofisticadas do que aquelas realmente produzidas.

No que se refere ao recorte temporal, os resultados obtidos no trabalho empírico se limitam ao período dos últimos cinco anos, quando foram observadas flutuações intensas das 
taxas de mercado. Nesse sentido, as conclusões do trabalho quanto ao distanciamento entre os preços apurados pelas diferentes metodologias se referem tão somente ao período analisado.

\subsection{SUGESTÕES DE PESQUISAS FUTURAS}

Cabe notar que esta pesquisa não esgota o tema, mas, sim, abre caminho para novos estudos que apontem no sentido do aprimoramento da gestão da dívida pública. Desta forma, propõem-se uma agenda de pesquisa dando sequência a esta investigação sobre os impactos de uma possível adoção da marcação a mercado como metodologia de apuração do estoque da dívida pública.

Uma das mais importantes atribuições do gestor da dívida pública é a obtenção de um adequado balanceamento entre custos e riscos para a dívida pública. Não fez parte do escopo deste trabalho abordar os modelos estocásticos utilizados na formação de uma fronteira eficiente no plano de custos e riscos. Fica claro, porém, que a escolha de uma composição ótima de dívida pública é afetada pela metodologia de precificação dos títulos. Neste sentido, um aprofundamento desta pesquisa permitiria verificar como a metodologia de apuração do estoque poderia afetar as decisões quanto a estratégias futuras de endividamento da dívida pública.

Outra possível continuidade ao estudo seria investigar a forma como a transferência de risco de taxa de juros para os credores afeta a demanda por títulos públicos. Conforme abordado por Silva, Cabral e Baghdassarian (2009), boa parte dos demandantes de títulos públicos precisa respeitar limites quanto à exposição ao risco de mercado. Em momentos de alta volatilidade, o Value-at-Risk pode atingir níveis elevados e levar à redução da demanda por títulos públicos por parte dos investidores. Consequentemente, o governo poderia enfrentar dificuldades na implantação de estratégias de endividamento.

Uma terceira sugestão de pesquisa se refere aos indicadores estocásticos da dívida pública, como o Cost-at-Risk (CaR), o qual representa um importante indicador de risco de mercado da dívida pública. Segundo Silva, Cabral e Baghdassarian (2009), diferentemente dos indicadores tradicionais, que mostram um retrato do endividamento público numa determinada data de referência, o Cost-at-Risk (CaR) mensura, considerando um certo nível de significância, as possíveis variações que o estoque da dívida poderia sofrer dentro de um período focal determinado, provendo uma medida de incerteza com relação ao valor esperado do estoque no futuro (risco de mercado). O cálculo se baseia na simulação do valor do estoque de acordo com diferentes cenários estocásticos das variáveis de mercado: taxas de juros, índices de inflação e taxas cambiais. 
Neste sentido, considerando que os preços dos títulos são afetados pelas variações das taxas de juros de formas distintas, de acordo com o método adotado de apuração do estoque, a escolha da metodologia poderia afetar de maneira decisiva a mensuração do risco de mercado da carteira da dívida pública por este indicador e, consequentemente, as diferentes estratégias a serem implementadas na gestão da dívida pública.

Uma última questão que pode ser explorada em pesquisas futuras se refere à conciliação entre a apuração do estoque da dívida pública em valores de mercado e a contabilidade pública, uma vez que os registros contábeis devem refletir a metodologia adotada. Desta forma, constitui uma importante consequência deste estudo uma investigação acerca da adequação dos registros contábeis à mudança de metodologia na apuração do estoque da DPF, sobretudo no que se refere à volatilidade do estoque marcado a mercado. 


\section{REFERÊNCIAS}

ALESINA, A.; PERROTTI, R. The political economy of budget deficits. IMF Staff Paper, $n^{\circ} 42$, p. 1-37, 1995.

ALVES, Luiz Fernando. Brazilian public debt benchmark: a long-term strategy. 2009. Paper - IBI - The Institute of Brazilian Business \& Public Management Issues, The George Washington University, Minerva Program, Spring, Washington, D.C, 2009.

ALVES, L. F.; SILVA, A. C. Planejamento Estratégico da Dívida Pública Federal. In: SILVA, A. C; CARVALHO, L. O. de; MEDEIROS, O. L. (Org.). Dívida pública: a experiência brasileira. Brasília: Secretaria do Tesouro Nacional: Banco Mundial, 2009, p. 149-171.

ANBIMA. Código ANBIMA de regulação e melhores práticas. 2011. Disponível em: <http://www.anbima.com.br/mostra.aspx/?op=o\&id=101>. Acesso em: 28 out. 2015.

Código de Negociação de Instrumentos Financeiros da ANBIMA - Deliberação

no 18. 2013. Disponível em: <http://portal.anbima.com.br/tesouraria/regulacao/codigo-denegociacao-de-instrumentos-financeiros/Documents/Deliberacao_n18.pdf >. Acesso em: 20 jan. 2016.

BABBIE, Earl. Métodos de Pesquisas de Survey. Belo Horizonte: Ed. UFMG, 1999.

BAGHDASSARIAN, William. Avaliação da sustentabilidade fiscal sob incerteza. Cadernos de Finanças Públicas, no 7, Brasília, dez. 2006, p. 31-74.

Indicadores estocásticos de risco no processo de planejamento estratégico da dívida pública. Finanças Públicas: VIII Prêmio Tesouro Nacional - 2003. Coletânea de Monografias. Brasília: Secretaria do Tesouro Nacional, 2004.

BANCO CENTRAL DO BRASIL. Circular no 3.086 de 2002. Estabelece critérios para registro e avaliação contábil de títulos e valores mobiliários e de instrumentos financeiros derivativos pelos fundos de investimento financeiro, fundos de aplicação em quotas de fundos de investimento, fundos de aposentadoria programada individual e fundos de investimento no exterior. Brasília, DF: DOU, 15 fev. 2002.

Glossário. Disponível em: <http://www.bcb.gov.br/glossario.asp?idioma=p > Acesso em: 13 abr. 2016.

BANCO MUNDIAL; FUNDO MONETÁRIO INTERNACIONAL. Revised Guidelines for Public Debt Management. World Bank, 2014.

BARRO, Robert J. Are government bonds net wealth? Journal of Political Economy, v. 82, p. 1095-1117, 1974.

BM\&F BOVESPA. Manual de marcação a mercado. 2015. Disponível em: $<$ http://www.bmfbovespa.com.br/BancoBmfbovespa/download/Manual-de-Marcacao-aMercado.pdf>. Acesso em: 26 out. 2015. 
BOHN, Henning. Tax Smoothing with Financial Instruments. The American Economic Review, 80, n. 5, p. 1217-1230, 1990.

BONOMO, M. et al. A new framework for debt management in Brazil. Secretaria do Tesouro Nacional, 2003.

BORGES, Bráulio de Lima. Sustentabilidade e Limites de Endividamento Público: o caso brasileiro. XI Prêmio Tesouro Nacional - 2006. Brasília: ESAF, 2006.

BRASIL. Constituição da República Federativa do Brasil. 05 de outubro de 1988. Diário Oficial da União: Brasília, DF, 1988.

BRESSER-PEREIRA, Luiz Carlos. A administração pública gerencial: estratégia e estrutura para um novo Estado. Brasília: MARE/ENAP, 1996. 28p.

BUTKIEWICZ, James. The market value of outstanding government debt: Comment. Journal of Monetary Economics, $n^{\circ} 11$, v. 3, p. 373-379, 1983.

CABRAL, Rodrigo. How Strategically is Public Debt Being Managed Around the Globe? A Survey on Public Debt Management Strategies. The World Bank Treasury, mar. 2015.

CABRAL, Rodrigo; LOPES, Mariana. Benchmark para a Dívida Pública: duas abordagens alternativas. IX Prêmio Tesouro Nacional - 2004. Brasília: ESAF, 2004.

COLBANO, Fabiano; LEISTER, Mauricio. Dívida Pública: contribuições de uma gestão eficiente para a estabilidade econômica. In: BOUERI, Rogério; ROCHA, Fabiana; RODOPOULOS, Fabiana. (Org.). Avaliação da qualidade do gasto público e mensuração da eficiência. Brasília: Secretaria do Tesouro Nacional, 2015. p. 53-80.

CORREIA, Fernando; MEURER, Roberto. Política Fiscal, Sustentabilidade da Dívida Pública e Liquidez dos Títulos: Uma Análise para o Brasil. Estudos Econômicos, São Paulo, v. 38, n. 3, p. 639-667, 2008.

COSTA, Carlos Eugênio. Sustentabilidade da dívida pública. In: SILVA, A. C; CARVALHO, L. O. de; MEDEIROS, O. L. (Org.). Dívida pública: a experiência brasileira. Brasília: Secretaria do Tesouro Nacional: Banco Mundial, 2009. p. 81-100.

COX, W., HIRSCHHORN, E.. The market value of U.S. government debt: Monthly, 19421980. Journal of Monetary Economics, ${ }^{\circ}$ 11, mar 1983.

DEMBIERMONT, C. et al. A new database on general government debt. BIS Quarterly Review, p. 69-87, set. 2015.

DIPPELSMAN, Robert; DZIOBEK, Claudia; MANGAS, Carlos. What lies Beneath: Statistical Definition of Public Debt. IMF Staff Discussion Note, jul. 2012.

FARAGLIA, E., MARCET, A.; SCOTT, A.. Fiscal Insurance and Debt Management in OECD Economies. The Economic Journal, Royal Economic Society, no 118, p. 363-386, mar. 2008. 
FREITAS, C. E. A Reavaliação da Dívida Pública Federal Brasileira. Brasília - DF: Escola de Pós-Graduação em Economia, Fundação Getúlio Vargas, 1999.

FUNDO MONETÁRIO INTERNACIONAL. External Debt Statistics: Guide for Compilers and Users. 2013.

Government Finance Statistics Manual. 2014.

IMF Fiscal Monitor. World Economic and Financial Surveys. Acting Now, Acting Together. Washington: International Monetary Fund, abr. 2016.

GIAMBIAGI, Fabio; ALÉM, Ana Cláudia. Finanças Públicas: teoria e prática no Brasil. Rio de Janeiro: Elsevier, 2011. 498 p.

GIAVAZZI, F., PAGANO, M.. Confidence Crises and Public Debt Management. In: DORNBUSCH, R.; DRAGHI, M. (Org.). Public Debt Management: Theory and History. Cambridge: Cambridge University Press. 1990.

GUJARATI, Damodar. Econometria Básica. $3^{\text {a }}$ ed. São Paulo: Makron Books, 2000. 846 p.

GREENE, William H. Econometric Analysis. 5a ed. New Jersey: Prentice Hall, 2003. 1026 p.

HYNDMAN, Rob J., KOEHLER, Anne B.. Another look at measures of forecast accuracy. International Journal of Forecasting, v. 22, nº . 4, p. 679-688, oct-dec, 2006.

IRWIN, Timothy. Defining the Government's Debt and Deficit. Journal of Economic Surveys, v. 29, $\mathrm{n}^{\circ}$ 4, p. 711-732, 2015.

LEISTER, Maurício Dias. Diferenças metodológicas de indicadores de maturidade. Secretaria do Tesouro Nacional. 2012.

LIMA, Luiz Renato, SAMPAIO, Raquel, GAGLIANONE, Wagner. Limite de Endividamento e Sustentabilidade Fiscal no Brasil: Uma abordagem via modelo Quantílico Auto-Regressivo (QAR). Ensaios Econômicos. 2005.

LLUSSÁ, Fernanda Antonia Josefa. Credibilidade e Administração da dívida pública: um estudo para o Brasil. Prêmio BNDES de Economia. Rio de Janeiro, 1998.

MACAULAY, Frederick R. Some Theoretical Problems Suggested by the Movements of Interest Rates, Bond Yields and Stock Prices in the United States since 1856. New York: Columbia University Press for the National Bureau of Economic Research, 1938.

MARKOWITZ, Harry M. Portfolio selection. The Journal of Finance. [S.1.], v. 7, n. 1, p. 77-91, mar. 1952.

MEDEIROS, Otavio Ladeira de. Dívida Pública como Indicador de Sustentabilidade Fiscal e Sinalizador de Política Governamental. VIII Prêmio Tesouro Nacional - 2003. Coletânea de Monografias, Brasília: ESAF, 2003. 80 p. 
MENDONÇA, H. F. A importância do tamanho, do prazo médio, e da estrutura de vencimento para a administração da dívida pública: uma análise a partir dos modelos de Giavazzi-Pagano (1990) e de Calvo-Guidotti (1990). Economia e Sociedade (UNICAMP), Campinas - SP, v. 13, n. 1, p. 1-19, 2004.

MORI, Rogério, TAVARES, Guilherme, BUENO, Túlio. A crise da marcação a mercado em 2002: uma perspectiva histórica. Revista de Economia e Administração, São Paulo, 2006.

NETO, Alfredo Lopes da Silva. Os custos da dívida pública interna federal no Brasil. Revista de Administração Pública. Rio de Janeiro, 1983.

NOSBUSCH, Y. Interest costs and the optimal maturity structure of government debt. The Economic Journal, v.118, p. 477-498, 2008.

PEDRAS, Guilherme Binato Villela. A evolução da administração da dívida pública e risco de repúdio no Brasil. Escola de Pós-Graduação em Economia, Fundação Getúlio Vargas, 2003.

PEREIRA, Fabio Guelfi. Títulos públicos sem segredos: guia para investimentos no Tesouro Direto. Rio de Janeiro: Elsevier, 2009. 145p.

PUCCINI, Abelardo. Matemática Financeira objetiva e aplicada. $6^{\mathrm{a}}$ ed. São Paulo: Saraiva, 2002. 440p.

SEATER, John J. The market value of outstanding government debt, 1919-1975. Journal of Monetary Economics, no 8. p. 85-101, 1981.

SECRETARIA DO TESOURO NACIONAL. Características dos títulos públicos. Brasília, 2015a. Disponível em:

<http://www.tesouro.fazenda.gov.br/documents/10180/391338/Caracteristicas_Titulos_Public os.pdf>. Acesso em: 27 mai. 2016

Curso Básico de Dívida Externa. Brasília, ago. 2003a.

Disponível em:

Metodologia de Cálculo dos títulos emitidos em oferta pública. Brasília, 2003b.

<http://www3.tesouro.gov.br/legislacao/download/divida/decretos/Bonds_Versao_portugues_ atualizado_Revisado.pdf >. Acesso em: 27 mai. 2016

Plano Anual de Financiamento - 2015 (PAF-2015). Brasília, 2015b. Disponível em: <https://www.tesouro.fazenda.gov.br/pt/divida-publica-federal/plano-anual-definanciamento>. Acesso em: 27 mai. 2016

Precificação de títulos públicos. Brasília, 2015c. Disponível em:

<http://www.tesouro.fazenda.gov.br/documents/10180/391338/Precificação+dos+títulos+públ icos/3f1e409b-bfd9-45a0-aa9d-eefa5ed98468>. Acesso em: 27 mai. 2016

Relatório Mensal da Dívida Pública Federal (RMD). Brasília, 2015d. Disponível em: <https://www.tesouro.fazenda.gov.br/pt/divida-publica-federal/relatorio-mensal-dadivida>. Acesso em: 27 mai. 2016 
Sistema Séries Temporais. Brasília, 2015e. Disponível em:

$\langle\mathrm{http}: / / \mathrm{www}$ 3.tesouro.fazenda.gov.br/series_temporais/principal.aspx?tema=9\#ancora_consul ta>. Acesso em: 27 mai. 2016

SILVA, Aline D. B. de M., MEDEIROS, Otavio L. de. Conceitos e estatísticas da dívida pública. In: SILVA, A. C; CARVALHO, L. O. de; MEDEIROS, O. L. de; (Org.). Dívida pública: a experiência brasileira. Brasília: Secretaria do Tesouro Nacional: Banco Mundial, 2009, p. 101-128.

SILVA, Anderson C., CABRAL, Rodrigo, BAGHDASSARIAN, William. Gerenciamento de riscos da Dívida Pública Federal. In: SILVA, A. C; CARVALHO, L. O. de; MEDEIROS, O. L. de; (Org.). Dívida pública: a experiência brasileira. Brasília: Secretaria do Tesouro Nacional: Banco Mundial, 2009, p. 173-218.

TANNER, J. Ernest. An empirical investigation of tax discounting. Journal of Money, Credit and Banking, $\mathrm{n}^{\circ}$ 11, p. 214-218, 1979.

TAVARES, Ronnie G., TAVARES, Márcia F. T. Títulos públicos federais e suas formas de precificação. In: SILVA, A. C; CARVALHO, L. O. de; MEDEIROS, O. L. de; (Org.). Dívida pública: a experiência brasileira. Brasília: Secretaria do Tesouro Nacional: Banco Mundial, 2009, p. 307-337.

TOBIN, J. An essay on principles of debt management. In: Fiscal and debt managent polices, commission on money and credit. Englewood Cliffs: N. J., Prentice Hall, 1963, p. 143-218. 


\section{APÊNDICE A - QUESTIONÁRIO}

\section{Survey - valuation method of public debt statistics}

1. What is the valuation method used by your Debt Management Office for reporting public debt securities? Please check all that apply.

__ Nominal value or face value

__ Market value

__ Other method:

Comments (optional):

(Please skip this question if you checked 'market value' in question 01)

2. Does your Debt Management Office plan to report market values of public debt securities in the near future?

_ Yes ___ No

3. Do you calculate the market value of public debt for purposes other than reporting (for example, for internal consumption or analytical purposes such as pricing of liability management operations)?

_ $\mathrm{Yes} \_$No

For which purpose? (optional):

4. Please indicate your country: 
APÊNDICE B - RESPOSTAS À PESQUISA SURVEY

\begin{tabular}{|l|l|l|l|l|l|l|}
\hline País & Grupo & Método & Comentário & $\begin{array}{l}\text { Pretende } \\
\text { adotar } \\
\text { esse } \\
\text { método? }\end{array}$ & $\begin{array}{l}\text { Utiliza a } \\
\text { marcação } \\
\text { a } \\
\text { mercado? }\end{array}$ & Qual finalidade? \\
\hline África do Sul & Emergente & $\begin{array}{l}\text { Nominal } \\
\text { ou face }\end{array}$ & - & - & sim & - \\
\hline Antígua e Barbuda & Baixa renda & $\begin{array}{l}\text { Nominal } \\
\text { ou face }\end{array}$ & - & não & não & - \\
\hline Argentina & Emergente & $\begin{array}{l}\text { Nominal } \\
\text { ou face }\end{array}$ & - & não & sim & $\begin{array}{l}\text { For pricing of liability management } \\
\text { operations }\end{array}$ \\
\hline Armênia & Baixa renda & $\begin{array}{l}\text { Nominal } \\
\text { ou face }\end{array}$ & - & não & não & $\begin{array}{l}\text { Central Bank calculates the market value of } \\
\text { public debt securities for yield curves }\end{array}$ \\
\hline
\end{tabular}




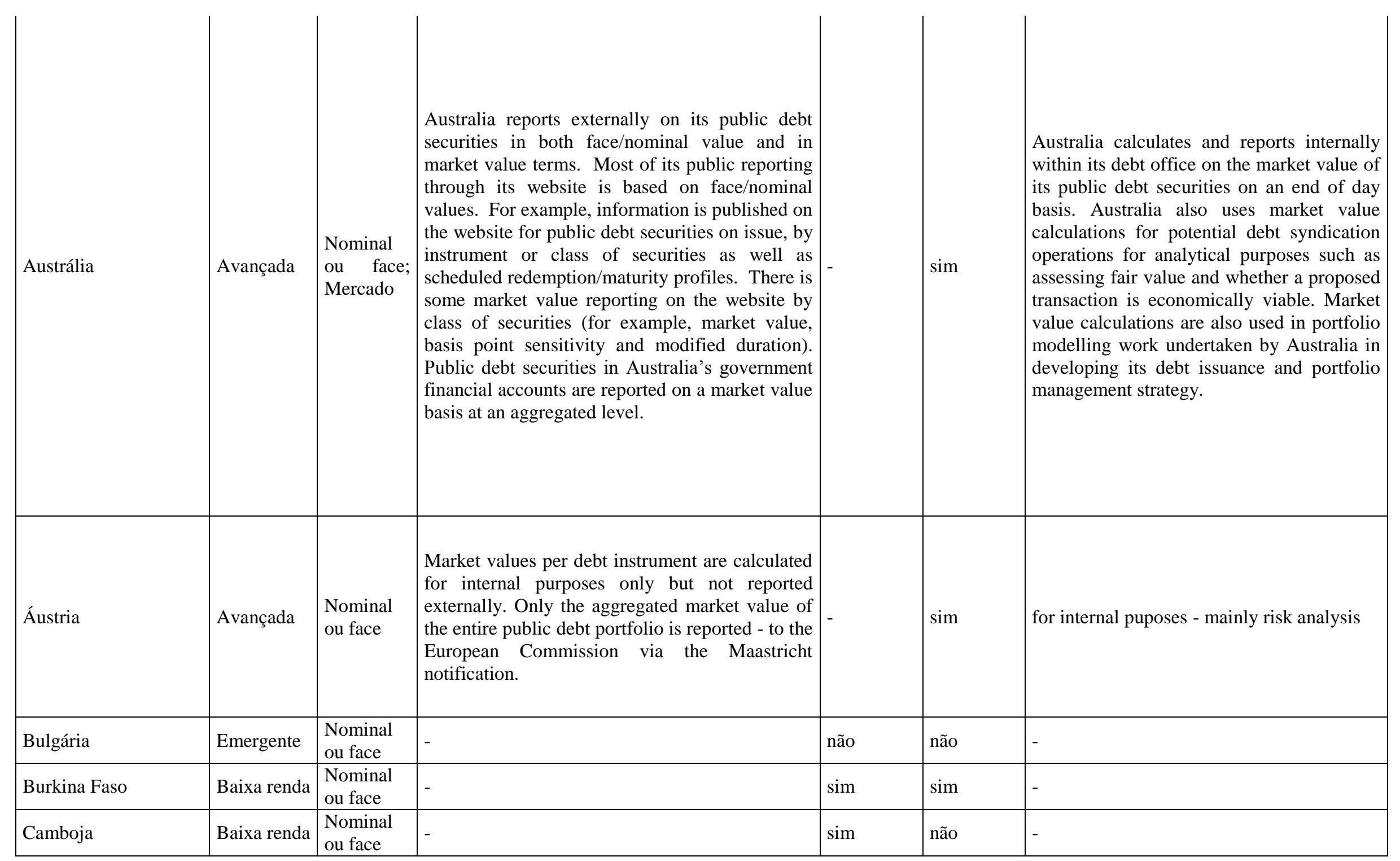




\begin{tabular}{|c|c|c|c|c|c|c|}
\hline Canadá & Avançada & $\begin{array}{l}\text { Nominal } \\
\text { ou face }\end{array}$ & - & não & não & - \\
\hline Chile & Emergente & $\begin{array}{l}\text { Nominal } \\
\text { ou face }\end{array}$ & - & não & $\operatorname{sim}$ & Liability management \\
\hline Colômbia & Emergente & $\begin{array}{l}\text { Nominal } \\
\text { ou face }\end{array}$ & - & $\operatorname{sim}$ & não & $\begin{array}{l}\text { We are about to begin to apply the market } \\
\text { valuation of the debt in order to price } \\
\text { adequately the liability management } \\
\text { opertions }\end{array}$ \\
\hline Dinamarca & Avançada & $\begin{array}{l}\text { Nominal } \\
\text { ou face; } \\
\text { Mercado }\end{array}$ & - & - & $\operatorname{sim}$ & - \\
\hline Etiópia & Baixa renda & \begin{tabular}{|l|}
$\begin{array}{l}\text { Nominal } \\
\text { ou face }\end{array}$ \\
\end{tabular} & - & não & não & - \\
\hline EUA & Avançada & $\begin{array}{l}\text { Nominal } \\
\text { ou face }\end{array}$ & - & não & $\operatorname{sim}$ & - \\
\hline Filipinas & Emergente & $\begin{array}{l}\text { Nominal } \\
\text { ou face }\end{array}$ & - & $\operatorname{sim}$ & $\operatorname{sim}$ & - \\
\hline França & Avançada & $\begin{array}{l}\text { Nominal } \\
\text { ou face }\end{array}$ & - & não & não & - \\
\hline Gâmbia & Baixa renda & $\begin{array}{l}\text { Nominal } \\
\text { ou face }\end{array}$ & - & $\operatorname{sim}$ & $\operatorname{sim}$ & Internal consumption \\
\hline Georgia & Baixa renda & \begin{tabular}{|l|} 
Nominal \\
ou face
\end{tabular} & - & não & não & - \\
\hline Holanda & Avançada & $\begin{array}{l}\text { Nominal } \\
\text { ou face }\end{array}$ & $\begin{array}{l}\text { Up until } 2015 \text {, the difference between the market } \\
\text { value of the debt and that of a benchmark portfolio } \\
\text { was reported annually. We will cease to do this as } \\
\text { of } 2016\end{array}$ & não & não & - \\
\hline Hungria & Emergente & $\begin{array}{l}\text { Nominal } \\
\text { ou face }\end{array}$ & $\begin{array}{l}\text { except discount T-bill, that is evaluated at } \\
\text { weighted average issue price }\end{array}$ & não & $\operatorname{sim}$ & pricing of LMO (bond exchange auctions) \\
\hline Índia & Emergente & $\begin{array}{l}\text { Nominal } \\
\text { ou face }\end{array}$ & - & não & não & - \\
\hline
\end{tabular}




\begin{tabular}{|c|c|c|c|c|c|c|}
\hline Japão & Avançada & $\begin{array}{l}\text { Nominal } \\
\text { ou face }\end{array}$ & $\begin{array}{l}\text { on principal amounts in proportion with the } \\
\text { consumer price index(CPI). }\end{array}$ & não & não & - \\
\hline Lituânia & Avançada & $\begin{array}{l}\text { Nominal } \\
\text { ou face }\end{array}$ & - & não & $\operatorname{sim}$ & $\begin{array}{l}\text { Liability management possibilities, also } \\
\text { market value is important when estimating if } \\
\text { the issue can be tapped (if market value is } \\
\text { significantly over par, tapps are not } \\
\text { recommended) }\end{array}$ \\
\hline
\end{tabular}




\begin{tabular}{|c|c|c|c|c|c|c|}
\hline Madagascar & Baixa renda & $\begin{array}{l}\text { Nominal } \\
\text { ou face }\end{array}$ & - & não & $\operatorname{sim}$ & - \\
\hline Maldivas & Baixa renda & $\begin{array}{l}\text { Nominal } \\
\text { ou face }\end{array}$ & - & não & não & - \\
\hline Marrocos & Emergente & $\begin{array}{l}\text { Nominal } \\
\text { ou face; } \\
\text { Mercado }\end{array}$ & $\begin{array}{l}\text { We use nominal value for domestic debt and for } \\
\text { bilateral and multilateral external debt and we use } \\
\text { market value for negotiable external debt } \\
\text { (government securities issued in International } \\
\text { Financial Market) }\end{array}$ & não & $\operatorname{sim}$ & $\begin{array}{l}\text { Pricing of liability management operations } \\
\text { and debt portfolio analysis and also pricing } \\
\text { of domestic securities for cash management } \\
\text { operations (repos) }\end{array}$ \\
\hline México & Emergente & $\begin{array}{l}\text { Nominal } \\
\text { ou face }\end{array}$ & - & não & $\operatorname{sim}$ & - \\
\hline Moldávia & Baixa renda & $\begin{array}{l}\text { Nominal } \\
\text { ou face }\end{array}$ & - & $\operatorname{sim}$ & $\operatorname{sim}$ & $\begin{array}{l}\text { for pricing the collateral in our open market } \\
\text { operations }\end{array}$ \\
\hline Nicarágua & Baixa renda & $\begin{array}{l}\text { Nominal } \\
\text { ou face; } \\
\text { Mercado }\end{array}$ & - & $\operatorname{sim}$ & $\operatorname{sim}$ & - \\
\hline Papua Nova Guiné & Baixa renda & Mercado & - & - & não & - \\
\hline Quirguistão & Baixa renda & $\begin{array}{l}\begin{array}{l}\text { Nominal } \\
\text { ou face }\end{array} \\
\end{array}$ & - & não & não & - \\
\hline R. D. do Congo & Baixa renda & Other & $\begin{array}{l}\text { we have only non-negotiable loan agreements. we } \\
\text { don't have financial market. }\end{array}$ & $\operatorname{sim}$ & não & - \\
\hline República Dominicana & Emergente & $\begin{array}{l}\text { Nominal } \\
\text { ou face }\end{array}$ & $\begin{array}{l}\text { In the debt statistics tables reported by the Public } \\
\text { Debt Office the securities are valued at face value, } \\
\text { but the Central Bank in the International } \\
\text { Investment Position, reports the securities issued } \\
\text { by the Government at market value. }\end{array}$ & não & $\operatorname{sim}$ & Internal consumption \\
\hline Sérvia & Emergente & $\begin{array}{l}\text { Nominal } \\
\text { ou face }\end{array}$ & - & não & $\operatorname{sim}$ & Yes, for liability management operations. \\
\hline
\end{tabular}




\begin{tabular}{|c|c|c|c|c|c|c|}
\hline Sri Lanka & Emergente & $\begin{array}{l}\text { Nominal } \\
\text { ou face }\end{array}$ & In house assessment of market value is practiced & $\operatorname{sim}$ & $\operatorname{sim}$ & $\begin{array}{l}\text { Mainly for the purpose of ascertaining } \\
\text { discounting and premium component of } \\
\text { outstanding stock and to facilitate coupon } \\
\text { decisions in the financing year. }\end{array}$ \\
\hline Suécia & Avançada & $\begin{array}{l}\text { Nominal } \\
\text { ou face; } \\
\text { Mercado }\end{array}$ & $\begin{array}{l}\text { Regarding valuation to nominal value: } \\
\text { External debt is marked to current exchange rate } \\
\text { Inflation-linked debt includes accrued inflation } \\
\text { compensation }\end{array}$ & - & não & - \\
\hline Tanzânia & Baixa renda & $\begin{array}{l}\text { Nominal } \\
\text { ou face }\end{array}$ & - & não & não & - \\
\hline Turquia & Emergente & $\begin{array}{l}\text { Nominal } \\
\text { ou face; } \\
\text { Mercado; } \\
\text { Others }\end{array}$ & $\begin{array}{l}\text { Debt stock figures based on principal amounts are } \\
\text { also reported on our web site regularly. Face and } \\
\text { Market values are compiled consecutively for } \\
\text { reporting Excessive Debt Procedure debt to } \\
\text { EUROSTAT and Government Finance Statistics } \\
\text { tables to IMF. }\end{array}$ & - & não & - \\
\hline Ucrânia & Emergente & $\begin{array}{l}\text { Nominal } \\
\text { ou face }\end{array}$ & According to national legislation & não & não & - \\
\hline Uganda & Baixa renda & $\begin{array}{l}\text { Nominal } \\
\text { ou face }\end{array}$ & - & sim & não & - \\
\hline Uruguai & Emergente & $\begin{array}{l}\text { Nominal } \\
\text { ou face }\end{array}$ & - & não & $\operatorname{sim}$ & $\begin{array}{l}\text { Liability Management, Debt Buybacks, } \\
\text { Reopening of Securties and new securities } \\
\text { issuances. }\end{array}$ \\
\hline Zâmbia & Baixa renda & $\begin{array}{l}\text { Nominal } \\
\text { ou face }\end{array}$ & - & não & não & - \\
\hline
\end{tabular}




\section{APÊNDICE C - DADOS DA REGRESSÃO MÚLTIPLA}

\begin{tabular}{|c|c|c|c|c|c|c|}
\hline RMSE & Desvio Padrão & Duration & Dólar & Flutuante & Índice de preços & Prefixado \\
\hline $0,05 \%$ & $0,68 \%$ & 0,25 & 0 & 0 & 0 & 1 \\
\hline $0,25 \%$ & $1,34 \%$ & 0,50 & 0 & 0 & 0 & 1 \\
\hline $0,21 \%$ & $0,37 \%$ & 0,75 & 0 & 0 & 0 & 1 \\
\hline $0,35 \%$ & $1,51 \%$ & 1,21 & 0 & 0 & 0 & 1 \\
\hline $0,69 \%$ & $2,05 \%$ & 1,50 & 0 & 0 & 0 & 1 \\
\hline $0,62 \%$ & $3,69 \%$ & 1,23 & 0 & 0 & 0 & 1 \\
\hline $1,47 \%$ & $2,80 \%$ & 2,00 & 0 & 0 & 0 & 1 \\
\hline $2,12 \%$ & $3,59 \%$ & 2,23 & 0 & 0 & 0 & 1 \\
\hline $2,89 \%$ & $4,25 \%$ & 2,31 & 0 & 0 & 0 & 1 \\
\hline $0,18 \%$ & $0,59 \%$ & 1,23 & 0 & 0 & 0 & 1 \\
\hline $2,64 \%$ & $3,92 \%$ & 2,48 & 0 & 0 & 0 & 1 \\
\hline $1,85 \%$ & $1,65 \%$ & 2,33 & 0 & 0 & 0 & 1 \\
\hline $0,93 \%$ & $1,41 \%$ & 2,22 & 0 & 0 & 0 & 1 \\
\hline $0,35 \%$ & $1,08 \%$ & 1,25 & 0 & 0 & 0 & 1 \\
\hline $4,00 \%$ & $2,33 \%$ & 3,98 & 0 & 0 & 0 & 1 \\
\hline $2,03 \%$ & $2,57 \%$ & 2,48 & 0 & 0 & 0 & 1 \\
\hline $1,37 \%$ & $2,86 \%$ & 2,24 & 0 & 0 & 0 & 1 \\
\hline $0,37 \%$ & $2,05 \%$ & 1,25 & 0 & 0 & 0 & 1 \\
\hline $2,73 \%$ & $1,91 \%$ & 3,98 & 0 & 0 & 0 & 1 \\
\hline $0,72 \%$ & $1,48 \%$ & 2,21 & 0 & 0 & 0 & 1 \\
\hline $4,94 \%$ & $3,59 \%$ & 3,72 & 0 & 0 & 0 & 1 \\
\hline $1,49 \%$ & $2,26 \%$ & 2,25 & 0 & 0 & 0 & 1 \\
\hline $4,88 \%$ & $3,51 \%$ & 3,74 & 0 & 0 & 0 & 1 \\
\hline $2,22 \%$ & $2,01 \%$ & 3,73 & 0 & 0 & 0 & 1 \\
\hline $2,36 \%$ & $1,97 \%$ & 2,24 & 0 & 0 & 0 & 1 \\
\hline $2,95 \%$ & $1,36 \%$ & 3,96 & 0 & 0 & 0 & 1 \\
\hline $4,63 \%$ & $2,00 \%$ & 3,98 & 0 & 0 & 0 & 1 \\
\hline $5,13 \%$ & $2,00 \%$ & 3,95 & 0 & 0 & 0 & 1 \\
\hline $5,61 \%$ & $2,45 \%$ & 3,96 & 0 & 0 & 0 & 1 \\
\hline $0,26 \%$ & $4,70 \%$ & 0,93 & 0 & 0 & 0 & 1 \\
\hline $1,43 \%$ & $2,37 \%$ & 1,77 & 0 & 0 & 0 & 1 \\
\hline $3,52 \%$ & $5,59 \%$ & 2,53 & 0 & 0 & 0 & 1 \\
\hline
\end{tabular}




\begin{tabular}{|c|c|c|c|c|c|c|}
\hline RMSE & Desvio Padrão & Duration & Dólar & Flutuante & Índice de precos & Prefixado \\
\hline $3,61 \%$ & $2,04 \%$ & 3,22 & 0 & 0 & 0 & 1 \\
\hline $4,78 \%$ & $1,99 \%$ & 4,37 & 0 & 0 & 0 & 1 \\
\hline $6,42 \%$ & $1,97 \%$ & 4,61 & 0 & 0 & 0 & 1 \\
\hline $6,10 \%$ & $4,01 \%$ & 4,70 & 0 & 0 & 0 & 1 \\
\hline $6,82 \%$ & $2,18 \%$ & 6,02 & 0 & 0 & 0 & 1 \\
\hline $9,39 \%$ & $1,77 \%$ & 6,59 & 0 & 0 & 0 & 1 \\
\hline $7,49 \%$ & $1,36 \%$ & 6,50 & 0 & 0 & 0 & 1 \\
\hline $0,00 \%$ & $0,01 \%$ & 0,20 & 0 & 1 & 0 & 0 \\
\hline $0,00 \%$ & $0,01 \%$ & 0,45 & 0 & 1 & 0 & 0 \\
\hline $0,00 \%$ & $0,00 \%$ & 0,72 & 0 & 1 & 0 & 0 \\
\hline $0,00 \%$ & $0,00 \%$ & 0,87 & 0 & 1 & 0 & 0 \\
\hline $0,00 \%$ & $0,00 \%$ & 0,97 & 0 & 1 & 0 & 0 \\
\hline $0,00 \%$ & $0,00 \%$ & 1,18 & 0 & 1 & 0 & 0 \\
\hline $0,02 \%$ & $0,03 \%$ & 1,69 & 0 & 1 & 0 & 0 \\
\hline $0,01 \%$ & $0,03 \%$ & 1,88 & 0 & 1 & 0 & 0 \\
\hline $0,02 \%$ & $0,02 \%$ & 2,17 & 0 & 1 & 0 & 0 \\
\hline $0,02 \%$ & $0,02 \%$ & 2,42 & 0 & 1 & 0 & 0 \\
\hline $0,03 \%$ & $0,03 \%$ & 2,68 & 0 & 1 & 0 & 0 \\
\hline $0,04 \%$ & $0,03 \%$ & 2,96 & 0 & 1 & 0 & 0 \\
\hline $0,04 \%$ & $0,03 \%$ & 3,17 & 0 & 1 & 0 & 0 \\
\hline $0,05 \%$ & $0,02 \%$ & 3,68 & 0 & 1 & 0 & 0 \\
\hline $0,07 \%$ & $0,03 \%$ & 4,18 & 0 & 1 & 0 & 0 \\
\hline $0,07 \%$ & $0,03 \%$ & 4,68 & 0 & 1 & 0 & 0 \\
\hline $0,09 \%$ & $0,03 \%$ & 4,56 & 0 & 1 & 0 & 0 \\
\hline $0,10 \%$ & $0,03 \%$ & 5,68 & 0 & 1 & 0 & 0 \\
\hline $0,12 \%$ & $0,03 \%$ & 6,17 & 0 & 1 & 0 & 0 \\
\hline $0,13 \%$ & $0,03 \%$ & 6,65 & 0 & 1 & 0 & 0 \\
\hline $0,13 \%$ & $0,00 \%$ & 6,60 & 0 & 1 & 0 & 0 \\
\hline $0,10 \%$ & $0,00 \%$ & 5,63 & 0 & 1 & 0 & 0 \\
\hline $0,06 \%$ & $0,00 \%$ & 5,60 & 0 & 1 & 0 & 0 \\
\hline $0,06 \%$ & $0,00 \%$ & 6,09 & 0 & 1 & 0 & 0 \\
\hline $0,01 \%$ & $0,00 \%$ & 6,10 & 0 & 1 & 0 & 0 \\
\hline $0,08 \%$ & $0,00 \%$ & 6,10 & 0 & 1 & 0 & 0 \\
\hline $0,01 \%$ & $0,00 \%$ & 6,29 & 0 & 1 & 0 & 0 \\
\hline $1,05 \%$ & $6,59 \%$ & 0,37 & 0 & 0 & 1 & 0 \\
\hline
\end{tabular}




\begin{tabular}{|c|c|c|c|c|c|c|}
\hline RMSE & Desvio Padrão & Duration & Dólar & Flutuante & Índice de precos & Prefixado \\
\hline $0,37 \%$ & $1,52 \%$ & 0,85 & 0 & 0 & 1 & 0 \\
\hline $1,26 \%$ & $1,95 \%$ & 1,54 & 0 & 0 & 1 & 0 \\
\hline $2,92 \%$ & $4,53 \%$ & 2,22 & 0 & 0 & 1 & 0 \\
\hline $4,06 \%$ & $3,73 \%$ & 3,24 & 0 & 0 & 1 & 0 \\
\hline $6,24 \%$ & $6,20 \%$ & 3,88 & 0 & 0 & 1 & 0 \\
\hline $3,36 \%$ & $1,50 \%$ & 4,75 & 0 & 0 & 1 & 0 \\
\hline $6,57 \%$ & $1,63 \%$ & 5,35 & 0 & 0 & 1 & 0 \\
\hline $5,06 \%$ & $1,22 \%$ & 5,68 & 0 & 0 & 1 & 0 \\
\hline $1,92 \%$ & $0,59 \%$ & 4,57 & 0 & 0 & 1 & 0 \\
\hline $7,22 \%$ & $2,18 \%$ & 7,31 & 0 & 0 & 1 & 0 \\
\hline $8,82 \%$ & $1,14 \%$ & 8,11 & 0 & 0 & 1 & 0 \\
\hline $3,54 \%$ & $0,58 \%$ & 7,16 & 0 & 0 & 1 & 0 \\
\hline $12,32 \%$ & $4,50 \%$ & 9,36 & 0 & 0 & 1 & 0 \\
\hline $9,23 \%$ & $1,12 \%$ & 11,71 & 0 & 0 & 1 & 0 \\
\hline $15,29 \%$ & $2,10 \%$ & 13,34 & 0 & 0 & 1 & 0 \\
\hline $13,96 \%$ & $0,00 \%$ & 14,39 & 0 & 0 & 1 & 0 \\
\hline $17,46 \%$ & $3,53 \%$ & 15,55 & 0 & 0 & 1 & 0 \\
\hline $14,58 \%$ & $1,05 \%$ & 16,00 & 0 & 0 & 1 & 0 \\
\hline $7,98 \%$ & $0,73 \%$ & 15,54 & 0 & 0 & 1 & 0 \\
\hline $0,40 \%$ & $9,29 \%$ & 0,07 & 0 & 0 & 0 & 0 \\
\hline $5,70 \%$ & $6,66 \%$ & 1,66 & 0 & 0 & 0 & 0 \\
\hline $9,44 \%$ & $6,10 \%$ & 3,51 & 0 & 0 & 0 & 0 \\
\hline $23,20 \%$ & $8,81 \%$ & 5,01 & 0 & 0 & 0 & 0 \\
\hline $4,91 \%$ & $0,95 \%$ & 6,43 & 0 & 0 & 0 & 0 \\
\hline $3,40 \%$ & $10,56 \%$ & 0,58 & 1 & 0 & 0 & 0 \\
\hline $6,86 \%$ & $11,84 \%$ & 0,96 & 1 & 0 & 0 & 0 \\
\hline $12,32 \%$ & $9,77 \%$ & 2,26 & 1 & 0 & 0 & 0 \\
\hline $14,34 \%$ & $9,93 \%$ & 3,00 & 1 & 0 & 0 & 0 \\
\hline $12,34 \%$ & $6,71 \%$ & 3,63 & 1 & 0 & 0 & 0 \\
\hline $11,61 \%$ & $4,21 \%$ & 5,10 & 1 & 0 & 0 & 0 \\
\hline $25,18 \%$ & $6,16 \%$ & 6,56 & 1 & 0 & 0 & 0 \\
\hline $12,57 \%$ & $3,29 \%$ & 6,46 & 1 & 0 & 0 & 0 \\
\hline $36,47 \%$ & $10,08 \%$ & 6,17 & 1 & 0 & 0 & 0 \\
\hline $6,83 \%$ & $1,63 \%$ & 7,93 & 1 & 0 & 0 & 0 \\
\hline $12,01 \%$ & $1,61 \%$ & 9,10 & 1 & 0 & 0 & 0 \\
\hline
\end{tabular}


(Conclusão)

\begin{tabular}{|c|c|c|c|c|c|c|}
\hline RMSE & Desvio Padrão & Duration & Dólar & Flutuante & Índice de preços & Prefixado \\
\hline $44,77 \%$ & $8,80 \%$ & 8,76 & 1 & 0 & 0 & 0 \\
\hline $43,71 \%$ & $8,48 \%$ & 8,76 & 1 & 0 & 0 & 0 \\
\hline $28,89 \%$ & $4,72 \%$ & 9,00 & 1 & 0 & 0 & 0 \\
\hline $6,93 \%$ & $0,82 \%$ & 8,98 & 1 & 0 & 0 & 0 \\
\hline $39,11 \%$ & $6,43 \%$ & 9,74 & 1 & 0 & 0 & 0 \\
\hline $46,73 \%$ & $8,22 \%$ & 10,16 & 1 & 0 & 0 & 0 \\
\hline $30,67 \%$ & $3,66 \%$ & 11,89 & 1 & 0 & 0 & 0 \\
\hline $13,11 \%$ & $2,48 \%$ & 12,94 & 1 & 0 & 0 & 0 \\
\hline $32,58 \%$ & $12,21 \%$ & 3,75 & 1 & 0 & 0 & 0 \\
\hline $12,27 \%$ & $1,04 \%$ & 14,38 & 1 & 0 & 0 & 0 \\
\hline $17,70 \%$ & $1,11 \%$ & 15,63 & 1 & 0 & 0 & 0 \\
\hline $6,48 \%$ & $3,07 \%$ & 3,03 & 1 & 0 & 0 & 0 \\
\hline $11,70 \%$ & $10,99 \%$ & 3,76 & 0 & 0 & 0 & 0 \\
\hline $18,72 \%$ & $4,30 \%$ & 6,32 & 0 & 0 & 0 & 0 \\
\hline $10,58 \%$ & $1,64 \%$ & 7,67 & 0 & 0 & 0 & 0 \\
\hline $10,30 \%$ & $1,95 \%$ & 8,14 & 0 & 0 & 0 & 0 \\
\hline
\end{tabular}

